\title{
Vigilância de síndrome febril exantemática: estudo descritivo de casos com anticorpos da classe IgM contra o sarampo. Estado de São Paulo, 2000 a 2004
}

\author{
FLÁVIA HELENA CICCONE
}

Dissertação apresentada ao Programa de PósGraduação em Saúde Pública da Faculdade de Saúde Pública para obtenção do título de Mestre em Saúde Pública.

Área de Concentração: Epidemiologia

Orientador: Prof. Dr. Eliseu Alves Waldman

São Paulo 
É expressamente proibida a comercialização deste documento, tanto na sua forma impressa como eletrônica. Sua reprodução total ou parcial é permitida exclusivamente para fins acadêmicos e científicos, desde que na reprodução figure a identificação do autor, título, instituição e ano da dissertação. 
Obrigada...

Agradeço, especialmente, à minha mãe Nayr de Souza Ciccone (in memoriam) por sempre me incentivar a estudar e ao meu pai Flávio Ciccone pelo exemplo de trabalho e dedicação. 


\section{Agradecimentos}

Gostaria de expressar meus agradecimentos a todas as pessoas que de alguma forma contribuíram para que este trabalho fosse realizado:

Ao Prof. Dr. Eliseu Alves Waldman pela orientação, com valiosas críticas e sugestões que foram fundamentais para o aprimoramento deste estudo, por estar sempre presente e por se preocupar com o meu aprendizado e formação profissional.

Aos membros da banca examinadora, Prof. Dra. Rita de Cássia Barradas Barata, Prof. Dra. Silvia Figueiredo Costa e Prof. Dra. Lourdes Rehder de Andrade Vaz de Lima, pelas valiosas críticas e sugestões.

Ao Centro de Vigilância Epidemiológica "Prof. Alexandre Vranjac" da Secretaria de Estado da Saúde de São Paulo e à Divisão de Doenças de Transmissão Respiratória (DDTR) pela disponibilidade dos dados, oportunidade de aprendizado e formação profissional.

À Dra. Telma Regina Marques Pinto Carvalhanas, diretora da DDTR/ $\mathrm{CVE} / \mathrm{SES} / \mathrm{SP}$ e amiga, por todo apoio e incentivo ao desenvolvimento deste estudo, por ter me acolhido e me auxiliado no início do trabalho na DDTR.

Às profissionais Ana Maria, Suely, Cristina, Maria Isabel e Márcia, da Seção de Vírus Produtores de Exantemas do Laboratório do IAL Central, que processaram todos os testes incluídos neste estudo. Muito obrigada.

À amiga Mônica Tilli Reis P. Conde pela amizade incondicional, companheira nesta mesma caminhada desde a prova de seleção, sempre pronta para ouvir e colaborar em todos os momentos que precisei. Obrigada por sua generosidade. 
À amiga de infância Valesca Bononi Zipparro, que mesmo tendo pós-doutorado em ecologia ouviu atentamente sobre sarampo e IgM. Obrigada por toda a ajuda.

Às amigas Sandra Brito Cunha por me ensinar tabwin e por toda a torcida desde o início da pós e Angela Carvalho Freitas pela leitura crítica e atenta do projeto.

À amiga Ivana Jinkings pela ajuda com a nossa linda e difícil língua portuguesa.

Às amigas Alessandra Cristina Guedes Pellini e Maria Lucia Fadel Condino pela ajuda na qualificação e por estarem sempre prontas a contribuir.

À Dra. Helena Keico Sato pelo incentivo constante e discussões sobre o sarampo.

À Maria Inês Cappelletti Gonçalves Okai pela ajuda inicial com o banco de dados e por todas as dicas com o "PGM".

Aos queridos familiares de Ribeirão Preto: Maria Elza Bononi Zipparro (minha madrinha), Solange Nogueira Bataglion, César Bataglion, Mariangela Salata Cicconi e tio Adair Joaquim de Souza, por todo carinho e apoio.

Às amigas Helena Aparecida Barbosa e Luzia Auxiliadora Carelli pela amizade e carinho.

Aos bibliotecários da Biblioteca da Faculdade de Saúde Pública da USP, em especial, Maria Lúcia Evangelista de Faria Ferraz e José Estorniolo Filho pela disponibilidade, gentileza e ajuda com as referências bibliográficas.

Aos colegas da DDTR e do EPISUS-SP pela gostosa convivência diária e troca de experiências e conhecimentos. 


\author{
"The art of epidemiological thinking \\ is to draw conclusions \\ from imperfect data"
}

George W. Comstock

“...E aprendi que se depende sempre

De tanta, muita, diferente gente

Toda a pessoa sempre é as marcas

Das lições diárias de outras tantas pessoas"

Gonzaguinha 


\section{Resumo}

Ciccone FH. Vigilância de síndrome febril exantemática: estudo descritivo de casos com anticorpos da classe IgM contra o sarampo. Estado de São Paulo, 2000 a 2004 [dissertação de mestrado]. São Paulo: Faculdade de Saúde Pública da USP; 2007.

Objetivo: Descrever os casos de síndrome febril exantemática, identificados no estado de São Paulo entre 2000 e 2004, visando identificar possíveis resíduos de fonte de infecção do sarampo. Métodos: Estudo descritivo. As definições são as utilizadas pelo Plano de Eliminação do Sarampo. O estudo incluiu casos notificados à vigilância da síndrome febril exantemática apresentando anticorpos IgM para sarampo pelas técnicas de ELISA e/ou ELISA de captura. Descreveram-se os aspectos clínicos e epidemiológicos segundo características de tempo, espaço e pessoa. Resultados: Estudaram-se 463 casos possíveis de sarampo; 64,1\% e 29,8\% foram classificados, respectivamente, como casos expostos e não expostos à vacina; 15,3\% apresentaram clínica específica para sarampo e 12,1\% apresentaram complicações. Os grupos etários mais representados foram: 9 a 11 meses (36,5\%), um ano (32,8\%) e cinco anos ou mais (15,2\%). A distribuição no espaço e no tempo não sugere a ocorrência de casos relacionados entre si. Entre o final de 2000 e o início de 2002, os casos não expostos à vacina mantiveram-se em patamares elevados, coincidindo com a identificação de dois casos importados de sarampo. Conclusão: as limitações do estudo não permitem análises conclusivas a respeito da circulação do vírus do sarampo no estado de São Paulo, mas o estudo aponta para a necessidade da investigação exaustiva de possíveis resíduos de fontes de infecção entre: menores de nove meses, primo vacinados contra o sarampo abaixo de 10 meses, mulheres em idade fértil e casos não expostos à vacina contra o sarampo.

Descritores: sarampo, síndrome febril exantemática, vigilância, eliminação. 


\begin{abstract}
Ciccone FH. Vigilância de síndrome febril exantemática: estudo descritivo de casos com anticorpos da classe IgM contra o sarampo. Estado de São Paulo, 2000 a 2004./Febrile exanthematic syndrome surveillance: descriptive study of cases with antibody of IgM class anti-measles. State of São Paulo, 2000 to 2004 [dissertation]. São Paulo (BR): Faculdade de Saúde Pública da Universidade de São Paulo; 2007.
\end{abstract}

Objective: To describe cases of febrile exanthematic syndrome reported in the State of São Paulo between 2000 and 2004, in order to identify possible measles residual source of infection. Methods: A descriptive study, using the same definitions of Measles Elimination Plan. The study included reported cases of febrile exanthematic syndrome surveillance with antibody of $\lg \mathrm{M}$ class by ELISA and/or capture ELISA techniques. The clinical and epidemiological characteristics were described in terms of time, space and personal characteristics. Results: 463 possible cases of measles were analyzed: $64.1 \%$ and $29.8 \%$ were classified, respectively, as exposed and unexposed to vaccine; $15.3 \%$ presented specific measles clinical and $12.1 \%$ presented clinical complications. The age groups most represented were: 9 to 11 months (36.5\%), one year (32.8\%) and five years old or over (15.2\%). The temporal and spatial distribution did not suggest the presence of a chain of transmission of febrile exanthematic disease. Between the end of 2000 and the beginning of 2002, high levels of cases unexposed to vaccine were maintained, which coincided with the identification of two imported cases of measles. Conclusion: The limitations of the study did not allow conclusive analyses regarding the circulation of the measles virus in the State, but the study points towards the need to carry out exhaustive investigations on possible residual sources of infection among: infants under nine months old, first vaccinated against measles before the age of 10 months, women of fertile age and cases unexposed to anti-measles vaccine.

Descriptors: measles, febrile exanthematic syndrome, surveillance, elimination. 


\section{ÍNDICE}

1 INTRODUÇÃO

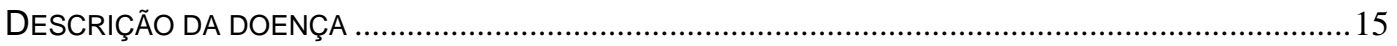

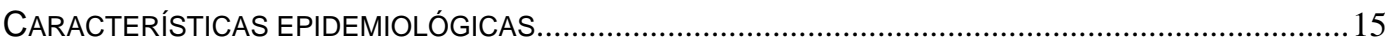

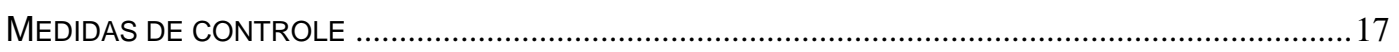

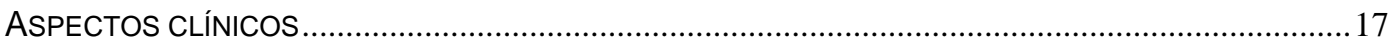

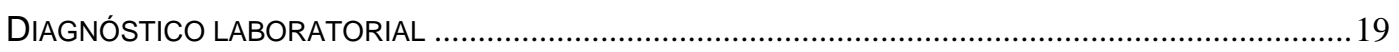

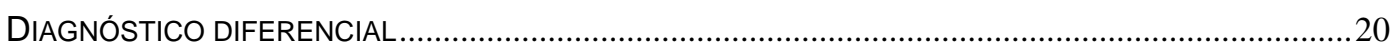

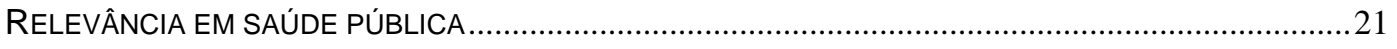

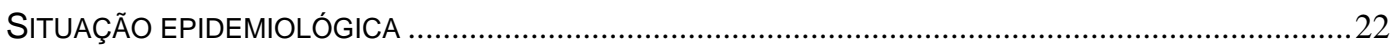

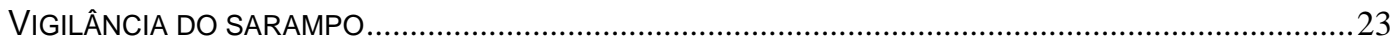

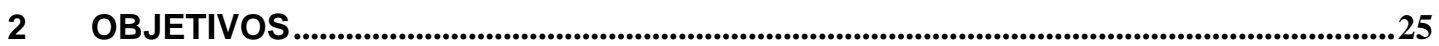

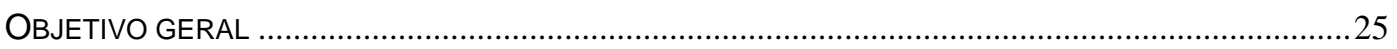

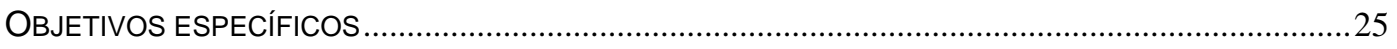

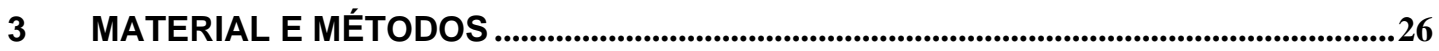

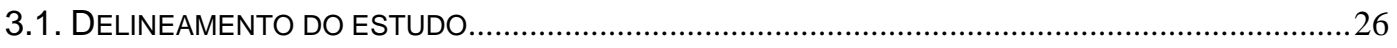

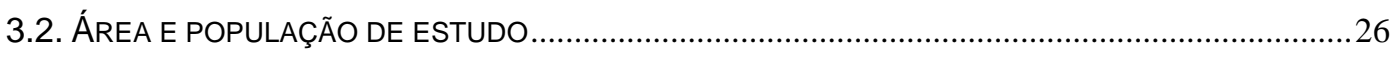

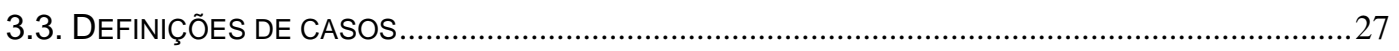

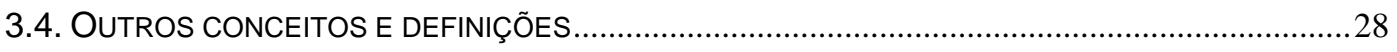

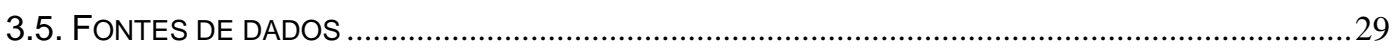

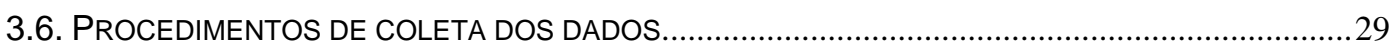

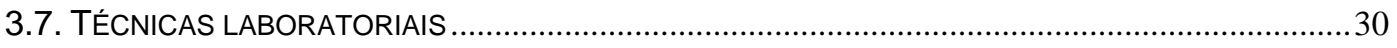

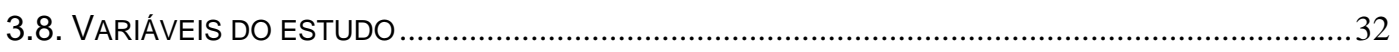

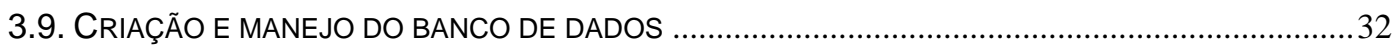

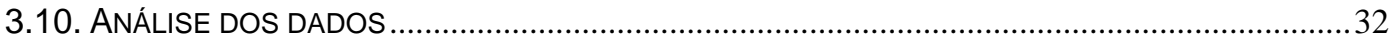

3.11. CONSIDERAÇÕES SOBRE ÉTICA EM PESQUISA …………………....................................3

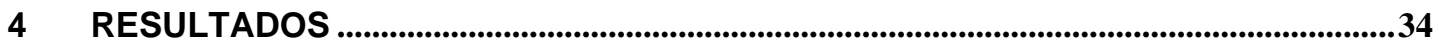

5 DISCUSSÃO

6 CONCLUSÃO .....................................................................................................................

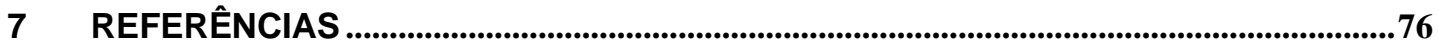

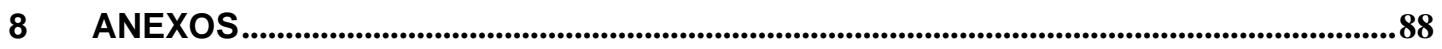

ANEXO 1. FICHA DE INVESTIGAÇÃO DE SARAMPO E RUBÉOLA (2000).........................................8

ANEXO 2. FICHA DE INVESTIGAÇÃO SARAMPO E RUBÉOLA (2001 A 2004) …..............................90 
ANEXO 3. TERMO DE COMPROMISSO.

ANEXO 4. APROVAÇÃO DO COMITÊ DE ÉTICA .. 


\section{Lista de Tabelas}

Tabela 1. Casos possíveis de sarampo segundo a faixa etária. Estado de São Paulo, 2000-2004

Tabela 2. Casos possíveis de sarampo segundo ano dos primeiros sintomas, sexo, idade e situação vacinal. Estado de São Paulo, 2000-2004

Tabela 3. Casos possíveis de sarampo segundo exposição à vacina do sarampo e características. Estado de São Paulo, 2000-2004

Tabela 4. Casos possíveis de sarampo segundo manifestações clínicas e exposição à vacina do sarampo. Estado de São Paulo, 20002004

Tabela 5. Casos possíveis de sarampo segundo principais complicações e exposição à vacina do sarampo. Estado de São Paulo, 20002004

Tabela 6. Casos possíveis de sarampo que referiram contato com casos semelhantes a sarampo e/ou rubéola segundo faixa etária e sexo. Estado de São Paulo, 2000-2004

Tabela 7. Casos possíveis de sarampo entre menores de nove meses ou com dez anos e mais segundo sexo e faixa etária. Estado de São Paulo, 2000-2004

Tabela 8. Casos possíveis de sarampo segundo número de doses, exposição à vacina do sarampo e faixa etária no momento da primo vacinação com o componente sarampo. Estado de São Paulo, 2000-2004

Tabela 9. Casos possíveis de sarampo segundo a faixa etária e o intervalo (em dias) entre a vacina com o componente sarampo e os primeiros sintomas. Estado de São Paulo, 2000-2004

Tabela 10. Casos possíveis de sarampo segundo faixa etária e situação vacinal. Estado de São Paulo, 2000-2004

Tabela 11. Casos possíveis de sarampo segundo intervalo entre a aplicação da vacina com o componente sarampo e a coleta para o diagnóstico do sarampo. Estado de São Paulo, 20002004 
Tabela 12. Casos possíveis de sarampo segundo resultado do exame imunodiagnóstico (Elisa: teste Behring e Elisa de captura: CDC). Estado de São Paulo, 2000-2004

Tabela 13. Casos possíveis de sarampo segundo exposição à vacina do sarampo e resultados de ELISA Behring e ELISA de captura (CDC) para IgM específico de sarampo. Estado de São Paulo, 2000-2004

Tabela 14. Casos possíveis de sarampo com resultado reagente para a imunoglobulina M (IgM) segundo intervalo entre o início do exantema e a coleta da amostra de sangue. Estado de São Paulo, 2000-2004

Tabela 15. Casos possíveis de sarampo com anticorpos da classe IgM contra a rubéola segundo exposição à vacina com o componente sarampo. Estado de São Paulo, 2000-2004

Tabela 16. Casos possíveis de sarampo com anticorpos da classe IgM 61 contra o herpes vírus 6 (exantema súbito) segundo exposição à vacina com o componente sarampo. Estado de São Paulo, 2000-2004

Tabela 17. Casos possíveis de sarampo com anticorpos da classe IgM contra o Parvovírus B19 (eritema infeccioso) segundo exposição à vacina com o componente sarampo. Estado de São Paulo, 2000-2004 


\section{Lista de Figuras}

$\begin{array}{lll}\text { Figura 1. } & \text { Diagrama da patogênese do sarampo }\end{array}$

Figura 2. Sistema de vigilância do sarampo no estado de São Paulo 24

Figura 3. Algoritmo de investigação etiológica utilizado para os casos $\quad 31$ com presença de anticorpos da classe IgM contra o sarampo

Figura 4. Total dos casos suspeitos e classificação dos casos possíveis de sarampo segundo exposição à vacina do sarampo. Estado de São Paulo, 2000-2004

Figura 5. Casos possíveis de sarampo distribuídos mês a mês segundo a faixa etária e a data dos primeiros sintomas. Estado de São Paulo, 2000-2004

Figura 6. Casos possíveis de sarampo segundo a semana epidemiológica (SE) e o ano dos primeiros sintomas. Estado de São Paulo, 2000-2004

Figura 7. Taxa de incidência (por 100.000 habitantes) dos casos possíveis de sarampo segundo região do estado e mês dos primeiros sintomas. Estado de São Paulo, 2001

Figura 8. Taxa de incidência (por 100.000 habitantes) dos casos possíveis de sarampo segundo Direção Regional de Saúde (DIR) de residência e ano dos primeiros sintomas. Estado de São Paulo. 2000-2004

Figura 9. Taxa de incidência (por 100.000 habitantes) dos casos possíveis de sarampo segundo município de residência e ano dos primeiros sintomas. Estado de São Paulo. 2000-2004

Figura 10. Taxa de incidência (por 100.000 habitantes) dos casos possíveis de sarampo segundo distrito administrativo (DA) de residência e ano dos primeiros sintomas. Município de São Paulo, 2000-2004

Figura 11. Casos possíveis de sarampo distribuídos mês a mês segundo a exposição à vacina do sarampo e a data dos primeiros sintomas. Estado de São Paulo, 2000-2004 


\section{Lista de abreviaturas}

CDC Centers for Disease Control and Prevention

CVE-SP Centro de Vigilância Epidemiológica do estado de São Paulo

DA Distrito Administrativo

DIR Direção Regional de Saúde

ELISA "Enzyme-Linked Immunosorbent Assay"

Técnica imunoenzimática

FII Ficha individual de investigação específica de doenças

exantemáticas febris - sarampo e rubéola

IAL Instituto Adolfo Lutz

IgM Imunoglobulina M

MS Ministério da Saúde

OMS Organização Mundial de Saúde

OPAS Organização Pan-americana de Saúde

PCR Reação em cadeia de polimerase

PEESA Panencefalite esclerosante subaguda

SE Semana Epidemiológica

SINAN Sistema de Informação de Agravos de Notificação

SPSS Statistical Package for Social Sciences

VE Vigilância Epidemiológica

VIGIFEX Vigilância da síndrome febril e exantemática

USP Universidade de São Paulo 


\section{INTRODUÇÃO}

O sarampo é uma doença infecciosa viral aguda exantemática, de elevada transmissibilidade, imunoprevenível, que pode apresentar formas graves com alta letalidade em alguns grupos de risco, especialmente crianças menores de cinco anos e desnutridas (SES, 2002; ACADEMIA AMERICANA DE PEDIATRIA, 2003; MS, 2003; GERSHON, 2005a; KUSCHNAROFF, 2005; CDC, 2007a).

\section{Descrição da doença}

O vírus do sarampo é classificado na família Paramyxoviridae e gênero Morbillivirus (GRIFFIN, 2001; SES, 2002; ACADEMIA AMERICANA DE PEDIATRIA, 2003; GERSHON, 2005a; KUSCHNAROFF, 2005; CDC, 2007a; MOSS e OTA, 2007). Existe somente um único tipo antigênico do vírus do sarampo. Estudos têm documentado alterações na proteína $\mathrm{H}$, entretanto essas modificações não parecem ser epidemiologicamente importantes, porque nenhuma mudança na eficácia da vacina tem sido observada (CDC, 2007a).

$\mathrm{O}$ vírus do sarampo é facilmente inativado pelo calor, luz, $\mathrm{pH}$ extremos, éter, entre outros (GERSHON, 2005a; ARANDA, 2006; CDC, 2007a). Sobrevive por um curto período de tempo no ar, nos objetos e nas superfícies (GERSHON, 2005a; ARANDA, 2006; CDC, 2007a; MOSS e OTA, 2007).

\section{Características epidemiológicas}

As bases da epidemiologia do sarampo foram apresentadas por um estudo clássico, de Peter Panum, durante uma grande epidemia nas ilhas Faroe, em 1846 (Panum citado por GRIFFIN, 2001, p.1402; GERSHON, 2005a, p.2032; MOSS e OTA, 2007, p.605).

A única fonte de infecção é o homem, não existindo reservatório animal conhecido (ARANDA, 2006; CDC, 2007a; MOSS e OTA, 2007). O período de incubação é, em média, de dez dias até os pródromos e, 
geralmente, de 14 dias até o início do exantema, variando de sete a 18 dias (SES, 2002; ACADEMIA AMERICANA DE PEDIATRIA, 2003; GERSHON, 2005a; ARANDA, 2006; CDC, 2007a; MOSS e OTA, 2007).

O vírus do sarampo tem elevada infectividade, transmitindo-se de pessoa a pessoa por gotículas do trato respiratório na forma de aerossóis, especialmente em ambientes fechados (VARDAS e KREIS, 1999; GERSHON, 2005a; ARANDA, 2006; CDC, 2007a; MOSS e OTA, 2007).

O período de transmissibilidade do sarampo é de quatro dias antes até quatro dias após o início do exantema (ARANDA, 2006; CDC, 2007a).

A suscetibilidade da população ao sarampo é geral. Em populações urbanas não vacinadas, normalmente, mais de 95\% dos indivíduos suscetíveis contraem a doença. Não existe resistência natural, em qualquer idade as pessoas são suscetíveis, se não possuírem anticorpos para o sarampo (SES, 1998; SES, 2002; KUSCHNAROFF, 2005).

A imunidade ativa é adquirida por meio da infecção natural que é definitiva, ou pela vacinação que, apesar de induzir menores títulos de anticorpos do que a doença, sugere ser de longa duração e provavelmente por toda a vida (SES, 2002; GERSHON, 2005a; ARANDA, 2006; CDC, 2007a). Entretanto, apesar da vacina contra o sarampo ser considerada altamente eficaz, há vários registros na literatura sobre a ocorrência de surtos de sarampo em comunidades altamente vacinadas, sugerindo baixa imunidade de rebanho (AABY et al., 1986; MATHIAS et al., 1989; OZANNE e D'HALEWYN, 1992; CAMARGO et al., 2000).

As falhas vacinais, primárias e secundárias, têm sido apontadas como a razão de surtos em população altamente vacinada por diferentes motivos. A falha vacinal primária, não resposta à vacina, pode ocorrer por problemas operacionais de conservação e aplicação da vacina e interferência de anticorpos passivos de origem materna (MATHIAS et al., 1989; EDMONSON et al., 1990; PANNUTI et al., 2004).

Por sua vez, as falhas secundárias, caracterizadas pela produção inicial de anticorpos contra o sarampo como resposta ao estímulo vacinal e 
posterior diminuição desses anticorpos a níveis não protetores, podem ocorrer entre 2\% a 5\% dos vacinados (MATHIAS et al., 1989; OZANNE e D'HALEWIN, 1992; FOSTER et al., 1993; GERSHON, 2005a; CDC, 2007a).

A imunidade passiva é temporária e pode ser adquirida pela administração de imunoglobulina ou pelos anticorpos da classe lgG, de mães que tiveram a doença ou que foram vacinadas contra o sarampo, transferidos ao feto por via transplacentária, conferindo imunidade temporária durante o primeiro ano de vida (SES, 1998; SES, 2002; MS, 2003; MOSS e OTA, 2007). Em populações altamente vacinadas por longos períodos, sem transmissão endêmica do sarampo, a imunidade passiva é baixa e de pequena duração (KACICA et al., 1995; SZENBORN et al., 2003).

\section{Medidas de controle}

Em 1954, o vírus do sarampo foi isolado pela primeira vez, por Enders e Peebles, o que possibilitou o desenvolvimento da vacina, que é a principal forma de prevenir a ocorrência de casos de sarampo na comunidade (GRIFFIN, 2001; GERSHON, 2005a; CDC, 2007a; MOSS e OTA, 2007). É observado também que a imunoglobulina humana quando aplicada dentro de seis dias da exposição pode prevenir ou modificar o quadro clínico do sarampo (CDC, 2007a). Para interromper a transmissão comunitária pela imunidade de grupo é necessário, no mínimo, 95\% de cobertura vacinal homogeneamente distribuída. Para alcançar esse objetivo, várias estratégias de vacinação são utilizadas: campanhas de vacinação indiscriminadas (em massa, de seguimento), vacinação de rotina, de grupos de risco, vacinação frente a um caso suspeito (bloqueio) e vacinação frente a um caso confirmado (operação limpeza) (QUADROS et al., 1996; SES, 1998, 2002; QUADROS, 2002, 2004; MS, 2003).

\section{Aspectos clínicos}

O quadro clínico do sarampo é bastante característico e tem início com pródromos: febre alta, mal-estar geral, tosse, coriza, conjuntivite e fotofobia. Após essa fase, surge o exantema maculopapular inicialmente 
confluente na região retroauricular e na face, estendendo-se, em seguida, de forma centrífuga para o corpo. O exantema persiste, usualmente, de quatro a sete dias, podendo ser seguido de descamação furfurácea (SES, 2002; ACADEMIA AMERICANA DE PEDIATRIA, 2003; MS, 2003; GERSHON, 2005a; KUSCHNAROFF, 2005; ARANDA, 2006; CDC, 2007a; MOSS e OTA, 2007). Na figura 1, pode-se observar que o início do exantema coincide com o surgimento da resposta imune.

Figura 1. Diagrama da patogênese do sarampo.
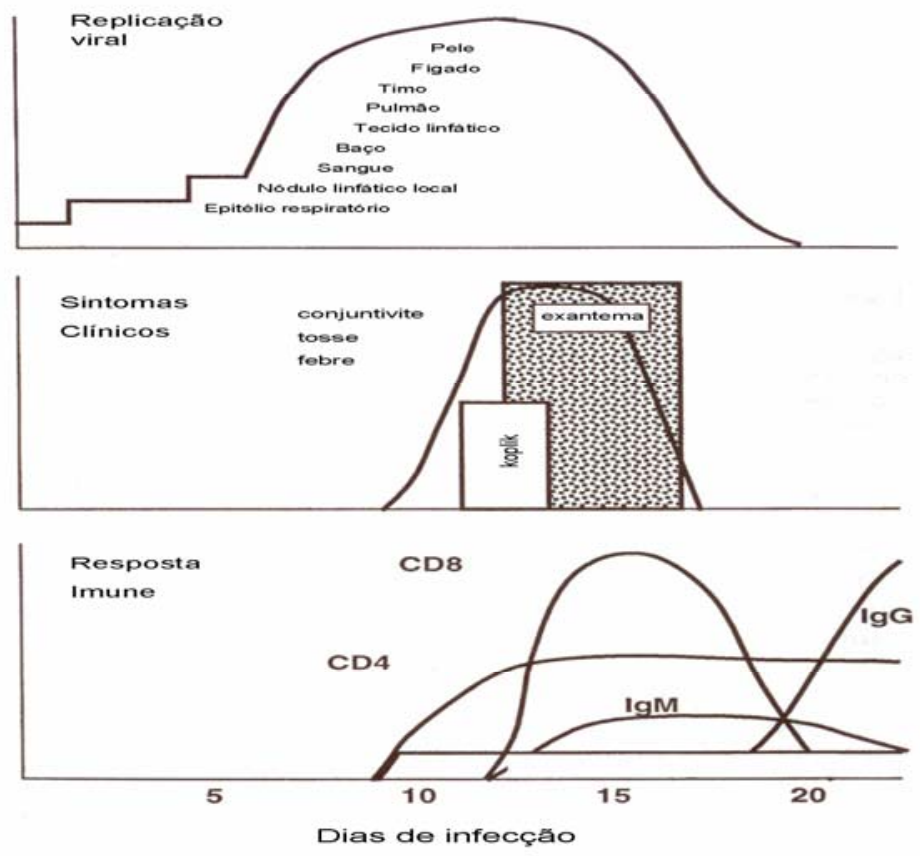

Fonte: Griffin DE. Measles Virus. In: Knipe DM, Howley PM, editors. Fields virology. 4. ed. Philadelphia: Lippincott Williams \& Wilkins; 2001

As principais complicações do sarampo são: pneumonia, otite média aguda, diarréia, entre outras, com maior risco nos desnutridos e nas idades extremas. As complicações neurológicas são raras, mas graves. A encefalite pode ocorrer em, aproximadamente, um em cada mil casos. A panencefalite 
esclerosante subaguda (PEESA) é uma doença degenerativa e irreversível do sistema nervoso central que leva ao óbito (ACADEMIA AMERICANA DE PEDIATRIA, 2003; CDC 2007a; MOSS e OTA, 2007).

Embora as manifestações clínicas sejam bastante marcantes, o sarampo pode suscitar dúvidas quanto ao diagnóstico, podendo ser confundido com outras doenças exantemáticas como a rubéola, exantema súbito, eritema infeccioso, escarlatina, dengue, entre outras (DAVIDKIN et al., 1998; STEWIEN et al., 2000; OLIVEIRA et al., 2001; OLIVEIRA et al., 2002; RAMSAY et al., 2002; ALONSO et al., 2003).

\section{Diagnóstico laboratorial}

Quando o sarampo é endêmico a confirmação de caso com fundamento no quadro clínico apresenta elevado valor preditivo positivo. Entretanto, o diagnóstico laboratorial é imprescindível onde a transmissão do sarampo está controlada (MOSS e OTA, 2007). Portanto, os casos suspeitos devem ser submetidos a testes laboratoriais, para a deteç̧ão de anticorpos da classe IgM, específicos do vírus do sarampo. O método de referência padrão para o diagnóstico da fase aguda do sarampo é a técnica imunoenzimática (ELISA) por cumprir vários critérios: reprodutibilidade, rapidez e eficiência no diagnóstico (BELLINI e HELFAND, 2003). Como alternativa, o diagnóstico pode ser realizado por meio da verificação da soroconversão, porém apresenta a desvantagem da necessidade de duas amostras de soros obtidos na fase aguda e de convalescença da doença. Existem também técnicas de isolamento viral com o cultivo do vírus em linhagem de células sensíveis (B95a) que permitem a sua replicação. $O$ vírus do sarampo pode ser isolado do sangue total, urina e secreções nasofaríngeas (SES, 2002; MS, 2003; BELLINI e HELFAND, 2003). Quando não é possível realizar o isolamento viral, podem ser utilizadas técnicas de biologia molecular com extração de material genético (RNA viral) das amostras clínicas, realização de reação em cadeia de polimerase (PCR), após transcrição reversa (RT-PCR), seqüenciamento e análise filogenética para a caracterização genotípica do vírus. O seqüenciamento viral é 
fundamental para conhecer o genótipo do vírus circulante no país e investigar a cadeia de transmissão do vírus (SES, 2002; MS, 2003; WHO, 2005). Apesar da caracterização molecular ser um componente importante da vigilância do sarampo, ela não é recomendada como método de rotina para o diagnóstico do sarampo devido a baixa sensibilidade, alto custo e demora no processamento (OSHITANI et al., 1997; GRIFFIN, 2001; SES, 2002; MS, 2003; ACADEMIA AMERICANA DE PEDIATRIA, 2003; CDC, 2007a; MOSS e OTA, 2007).

\section{Diagnóstico diferencial}

Várias doenças demonstram semelhança com o quadro clínico do sarampo e estão incluídas no diagnóstico diferencial. São elas: rubéola, exantema súbito, eritema infeccioso, escarlatina, dengue, mononucleose, entre outras causas de doença febril exantemática (DAVIDKIN et al., 1998; STEWIEN et al., 2000; OLIVEIRA et al., 2001; OLIVEIRA et al., 2002; RAMSAY et al., 2002; ALONSO et al., 2003).

A rubéola é uma doença benigna e sua importância deve-se à possibilidade de causar a síndrome da rubéola congênita. É bastante comum a rubéola apresentar infecções subclínicas. O período prodrômico, quando ocorre, é muito curto, em média de 24 a 36 horas. Em adolescentes e adultos esse período pode estar presente, com febre baixa, cefaléia, artralgia, linfadenopatia retroauricular, cervical e/ou occipital, conjuntivite, coriza e tosse. O exantema maculopapular, discreto, surge inicialmente na face, espalhando-se pelo tronco, membros superiores e membros inferiores, com duração média de um a seis dias (CHANTLER et al., 2001; SES, 2002; MS, 2003; GERSHON, 2005b; SATO, 2006; CDC, 2007b).

O exantema súbito, também chamado de roséola infantum ou sexta doença, tem como agente etiológico o herpes vírus humano tipo 6 (herpes vírus 6), afeta crianças menores de quatro anos, sendo mais freqüente nos primeiros dois anos de vida. Apresenta quadro clínico clássico com início abrupto de febre alta $\left(38-40^{\circ} \mathrm{C}\right)$ por três a quatro dias. Quando a febre desaparece tem início o exantema com duração média de um a dois dias, 
podendo eventualmente durar apenas algumas horas. Chama atenção o estado geral preservado da criança e a irritabilidade na vigência da febre. (HALL et al., 1994; YAMANISHI, 2001; SES, 2002; MS, 2003; STRAUS, 2005; MARQUES e SAKANE, 2006).

O eritema infeccioso, ou a quinta doença, tem como agente etiológico o parvovírus humano B19 (parvovírus B19), afeta principalmente crianças na faixa etária de cinco a 14 anos de idade. Habitualmente não há pródromos, entretanto ocasionalmente pode existir mal-estar, febre baixa e dor de garganta. O exantema tem início na face, onde é confluente e eritematoso, podendo apresentar a aparência de que a pessoa foi esbofeteada. Entre um a quatro dias, o exantema espalha-se para o tronco e membros, com aspecto rendilhado. A fase final do exantema é variável, pode apresentar recidiva devido a determinados fatores desencadeantes como exposição à luz solar, temperaturas extremas, exercícios ou estresse. Artralgias podem estar presentes principalmente nas mulheres (BLOOM e YOUNG, 2001; SES, 2002; MS, 2003; YOUNG e BROWN, 2004; BROWN, 2005; TEDESCO e AMATO NETO, 2006).

\section{Relevância em saúde pública}

A capacidade do sarampo em induzir uma diminuição da defesa imunitária, de certa forma, constitui o substrato para a manifestação da sua gravidade expressa pela letalidade que em países em desenvolvimento pode variar de $1 \%$ a $5 \%$. O espectro de eventos adversos à saúde relacionados ao sarampo, nessas populações, freqüentemente leva ao agravamento da desnutrição e à ampliação da morbi-mortalidade por diarréias e pneumonias (FOSTER et al., 1993).

A Organização Mundial de Saúde (OMS) estimou de 30 a 40 milhões de casos de sarampo no mundo, em 2000. O sarampo é considerado a principal causa de mortalidade por doença imunoprevenível em menores de quinze anos, com 777 mil óbitos, representando aproximadamente $47 \%$ do total dessas mortes. É responsável por 10\% de óbitos entre os menores de 
cinco anos de idade em todo o mundo (CDC, 1998; WHO, 2002; HENAORESTREPO et al., 2003; OTTEN et al., 2003; QUADROS, 2004).

\section{Situação epidemiológica}

A OMS estabeleceu metas para a eliminação do sarampo para três das suas seis regiões: as Américas para 2000, a Europa para 2007 e o Leste do Mediterrâneo para 2010 (HENAO-RESTREPO et al., 2003).

Com esse objetivo a Organização Pan-americana de Saúde (OPAS) recomendou estratégias de vacinação em massa, de rotina e de seguimento, além do fortalecimento da vigilância do sarampo (QUADROS et al., 1996, DOMINGUES et al., 1997; QUADROS, 2002, 2004). Como resultado observou-se queda de 99,3\% na morbidade pelo sarampo, de 1990 para 2000 na região das Américas (CDC, 2001; QUADROS et al., 2003). Além disso, verifica-se a ausência de casos autóctones de sarampo, durante longo período nesta década, em vários países que utilizaram as estratégias de vacinação recomendadas pela OPAS (CDC, 2003; QUADROS, 2004).

No Brasil, o sarampo é de notificação compulsória desde 1968 e a vacina contra a doença teve seu uso implementado e contínuo a partir de 1973 (DOMINGUES et al., 1997; SES, 1998; PREVOTS et al., 2003; ARANDA, 2006).

Em 1987, o estado de São Paulo iniciou com sucesso estratégia visando à eliminação do sarampo, com uma campanha de vacinação em massa nos menores de 14 anos, antes mesmo que essa meta fosse preconizada pela OPAS para a região das Américas (SES, 1998).

Em 1992, enquanto o Ministério da Saúde (MS) realizava campanha de vacinação semelhante, o estado de São Paulo implantou o Programa de Controle da Rubéola e da Síndrome da Rubéola Congênita, introduzindo a vacina tríplice viral (contra sarampo, caxumba e rubéola) no calendário básico de imunização, com uma campanha de vacinação em massa entre crianças de um a 10 anos. E a partir desse ano, a rubéola passou a ser doença de notificação compulsória no estado de São Paulo (DOMINGUES et al., 1997; SES, 1998; SATO, 2006). 
Apesar da drástica diminuição do sarampo em todo o país com a implantação dessas estratégias, em 1997 ocorreu uma ampla epidemia que atingiu a maioria dos estados brasileiros (SES, 2002; MS, 2003; PREVOTS et al., 2003; ARANDA, 2006). Após a epidemia houve um esforço bemsucedido, com a retomada do Plano de Eliminação do Sarampo (PES), possibilitando a interrupção da transmissão autóctone do sarampo no território nacional, por longo período a partir de 2001, com a identificação de casos importados e um surto recente no estado da Bahia, em 2006 (MS, 2003; PREVOTS et al., 2003; QUADROS et al., 2003; MS, 2005, 2006).

\section{Vigilância do sarampo}

Em áreas de baixa ocorrência ou ausência de casos autóctones de sarampo, a vigilância passa a ter entre seus objetivos a identificação de resíduos de suscetíveis e de fontes de infecção autóctones ou originárias de países onde a transmissão da doença ainda persiste.

Para alcançar essa meta a OPAS recomenda que a vigilância do sarampo seja altamente sensível na identificação de casos suspeitos (PAHO, 2001a; DIETZ et al., 2004). Uma das estratégias para alcançar esse objetivo é a vigilância de síndrome febril exantemática, à semelhança do que se aplica a vigilância da paralisia flácida aguda com a finalidade de identificar casos de poliomielite (ARITA, 2004).

No estado de São Paulo, a integração da vigilância e das atividades de controle do sarampo e da rubéola está implantada desde 1992. Existe uma rotina padronizada de forma que todo caso suspeito desses agravos deve ser notificado imediatamente à vigilância epidemiológica, investigado dentro de 48 horas, com coleta de uma amostra de sangue para diagnóstico e vacinação de bloqueio nos contatos (Figura 2). Essa integração também se aplica ao laboratório. Assim, todo caso suspeito de rubéola não confirmado por laboratório é imediatamente investigado para sarampo e vice-versa (SES, 2002). 
Figura 2. Sistema de vigilância do sarampo no estado de São Paulo.

Caso Suspeito de Sarampo

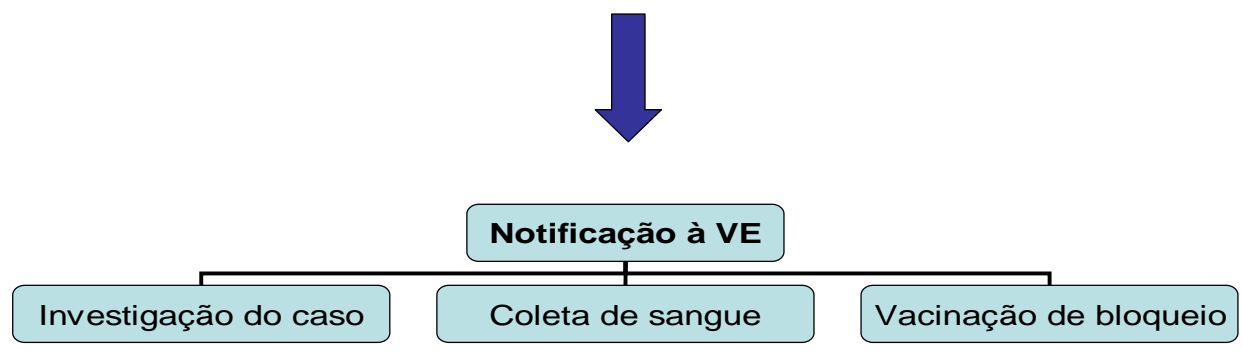

Entre 2003 e 2004, foi implantado o sistema de vigilância da síndrome febril e exantemática (VigiFEx), no município de Campinas, com o objetivo de conhecer os agentes etiológicos e a distribuição das doenças febris exantemáticas numa população em que o sarampo tenha sido eliminado (BARROS e SILVA, 2006).

O estado de São Paulo, de 2000 a 2004, apresentou uma média anual de 7.613 casos suspeitos de sarampo e rubéola por ano, com exceção do ano 2000, quando houve epidemia de rubéola no estado com 15.501 casos suspeitos de doenças exantemáticas. Existe, portanto, informação documentada por meio da ficha individual de investigação de todos os casos suspeitos desses agravos notificados à vigilância. É importante ressaltar que mais de $80 \%$ dos casos suspeitos tiveram amostra de sangue coletada para realização de imunodiagnóstico.

Considerando as dificuldades relativas à clínica e ao laboratório acima mencionadas, o número expressivo de casos no estado e a oportunidade para a melhor compreensão desses episódios num período de ausência de casos autóctones, este estudo descreve e analisa os casos de síndrome febril exantemática que apresentaram anticorpos da classe IgM específicos contra o sarampo. 


\section{OBJETIVOS}

\section{Objetivo geral}

Descrever e analisar os casos de síndrome febril exantemática, com presença de anticorpos da classe IgM contra o sarampo, no estado de São Paulo, entre 2000 e 2004, visando identificar possíveis resíduos de fonte de infecção.

\section{Objetivos específicos}

1. Descrever e analisar os casos com presença de anticorpos da classe IgM contra o sarampo, segundo caracteres epidemiológicos relativos a tempo, espaço e pessoa.

2. Descrever e analisar as manifestações clínicas e os aspectos relativos à história vacinal do grupo de interesse. 


\section{MATERIAL E MÉTODOS}

\subsection{Delineamento do estudo}

Estudo descritivo.

\section{2. Área e população de estudo}

A área de estudo é o estado de São Paulo, com aproximadamente 40 milhões de habitantes, distribuídos em 645 municípios, com 93,6\% de sua população em área urbana (SEADE, 2006).

A área metropolitana de São Paulo, formada por 39 municípios incluindo a capital do estado, possui aproximadamente a metade da população do estado (SEADE, 2006). O sistema de vigilância é descentralizado e sob a responsabilidade dos municípios que contam com o apoio de 24 Direções Regionais de Saúde (DIR). O Instituto Adolfo Lutz (IAL) é o laboratório de saúde pública de referência do estado de São Paulo, contando com o Laboratório Central e oito Laboratórios Regionais para o PES.

Durante o período deste estudo (2000 a 2004) não foram confirmados casos autóctones de sarampo no território brasileiro, com exceção do ano 2000, quando houve um surto com 15 casos no Acre e casos esporádicos em alguns estados, incluindo São Paulo (MS, 2003; PREVOTS et al., 2003; MS, 2005).

A população de estudo foi constituída por indivíduos atendidos nas diversas Unidades de Saúde do estado de São Paulo, entre 2000 e 2004, com suspeita de síndrome febril exantemática, que submetidos a testes de imunodiagnóstico para pesquisa de anticorpos da classe IgM contra o vírus da rubéola e do sarampo, mostraram-se reagentes para sarampo. 


\subsection{Definições de casos}

\section{Caso suspeito de sarampo}

Paciente que, independente da idade e da situação vacinal, apresentou febre e exantema acompanhados de um ou mais dos seguintes sinais e sintomas: tosse e/ou coriza e/ou conjuntivite (SES, 2002).

\section{Caso possível de sarampo}

Paciente residente no estado de São Paulo que, independente de sexo e/ou idade, entre janeiro de 2000 e dezembro de 2004, foi notificado ao sistema de vigilância como suspeito de síndrome febril exantemática, submetidos a pesquisa de anticorpos da classe IgM contra o vírus da rubéola e do sarampo, pelas técnicas ELISA e/ou ELISA de captura, mostraram-se reagentes para sarampo.

\section{Caso exposto à vacina}

Caso possível de sarampo com amostra de sangue coletada entre oito e 56 dias (HELFAND et al., 1999; DIETZ et al., 2004) após a aplicação da vacina monovalente de sarampo, dupla viral (contra sarampo e rubéola) ou tríplice viral (contra sarampo, caxumba e rubéola), independente da data dos primeiros sintomas.

\section{Critérios de inclusão}

Foram incluídos todos casos possíveis de sarampo, independente de apresentarem simultaneamente anticorpos da classe IgM contra outros vírus produtores de exantema.

\section{Critérios de exclusão}

Foram excluídos os pacientes que apresentaram anticorpos da classe IgM contra o sarampo em teste imunoenzimático (ELISA) em laboratórios particulares, que mostraram-se não reagentes ao teste confirmatório efetuado pelo laboratório de referência de saúde pública. 


\subsection{Outros conceitos e definições}

\section{Clínica específica de sarampo}

Febre com duração maior que dois dias e anterior ao aparecimento do exantema, este com duração mínima de três dias e, ambos os sintomas, acompanhados de tosse e/ou coriza e/ou conjuntivite.

\section{Caso autóctone de sarampo}

Caso confirmado de sarampo que contraiu a doença em território brasileiro.

\section{Caso confirmado de sarampo}

Paciente que apresentou clínica específica de sarampo, presença de anticorpos da classe IgM contra o sarampo pelo teste de imunodiagnóstico (ELISA e/ou ELISA de captura) e/ou PCR positivo, com ou sem vínculo epidemiológico com caso de sarampo confirmado.

\section{Evento adverso pós-vacina}

Presença de sintomatologia clínica de febre e/ou exantema, com início de cinco a 14 dias após a aplicação da vacina monovalente de sarampo, dupla viral (contra sarampo e rubéola) ou tríplice viral (contra sarampo, caxumba e rubéola), entre pacientes classificados como caso possível de sarampo exposto à vacina.

\section{Situação vacinal}

Foi considerado vacinado contra o sarampo o paciente que apresentou registro da aplicação de vacina, a partir de 1987, com o componente de sarampo na carteira de vacinação.

\section{Coleta oportuna}

Foi definida como coleta oportuna de amostra de sangue para teste diagnóstico do sarampo aquela realizada até o $28^{\circ}$ dia após o início do exantema. 


\subsection{Fontes de dados}

As fontes de dados utilizadas nesta pesquisa foram a Seção de Vírus Produtores de Exantemas do Laboratório do IAL Central, Laboratórios Regionais do IAL, sistema de vigilância de doenças exantemáticas, prontuários médicos e/ou fichas de atendimento ambulatorial ou hospitalar dos casos.

\subsection{Procedimentos de coleta dos dados}

Os dados referentes às diversas manifestações clínicas, história de contato e situação vacinal foram coletados da Ficha Individual de Investigação específica de Doenças Exantemáticas Febris - Sarampo e Rubéola, que seguiu dois modelos, o primeiro deles somente em 2000 (Anexos 1 e 2). Essas fichas foram encaminhadas ao Centro de Vigilância Epidemiológica (CVE) do estado de São Paulo por fax ou por transmissão eletrônica utilizando o Sistema de Informação de Agravos de Notificação (SINAN).

Essa ficha é preenchida, pelos profissionais das Unidades de Saúde e/ou pela equipe da vigilância epidemiológica (VE), no momento da suspeita do caso de sarampo ou rubéola, e completada posteriormente com o resultado do exame laboratorial.

Assim, os casos incluídos neste estudo foram identificados mediante atividade estabelecida na rotina da vigilância, com coleta de amostras de sangue, para exame imunodiagnóstico dos casos suspeitos de sarampo e rubéola, no primeiro contato da equipe de saúde com o paciente (SES, 1998, 2002; MS, 2003; DIETZ et al., 2004).

Todos os casos tiveram uma amostra de sangue coletada na fase aguda da doença, conforme as normas vigentes (SES, 2002; MS, 2003).

Além dessa atividade de rotina, foi desenvolvida investigação complementar, para este estudo, nos casos que não foram classificados como evento adverso pós-vacina. Nesses casos, quando necessário e com a finalidade de melhorar a qualidade da informação, foram levantados dados 
adicionais por meio de visita domiciliária, busca em prontuários e/ou contato telefônico.

\subsection{Técnicas laboratoriais}

Todos os exames foram processados pela rede de laboratórios do IAL. Para a detecção da imunoglobulina M (IgM) contra o sarampo foi utilizado o método imunoenzimático indireto, utilizando kit comercial Enzygnost ${ }^{\circledR}$ Anti-Masern-Virus/lgM Dade Behring (Behring), interpretado de acordo com as normas do fabricante e/ou método imunoenzimático de captura (ELISA de captura) com kit desenvolvido pelo Centers for Disease Control and Prevention (CDC), realizado pelo IAL conforme metodologia descrita (ERDMAN et al., 1991; HUMMEL et al., 1992), seguindo o protocolo fornecido pelo laboratório norte-americano.

Quando os testes apresentaram IgM reagente contra o sarampo (Behring) nos laboratórios regionais do IAL, as amostras de sangue foram encaminhadas ao IAL-Central para o teste ser repetido, desta vez utilizando a técnica de captura (CDC).

As técnicas laboratoriais utilizadas pelo IAL para o diagnóstico do sarampo são recomendadas pela OPAS e apresentam alta sensibilidade e especificidade (ERDMAN et al., 1991; RATNAM et al., 2000; TIPPLES et al., 2003; DIETZ et al., 2004).

Em alguns casos selecionados com quadro clínico sugestivo de sarampo foram coletadas amostras de sangue total e urina para o isolamento viral do sarampo. Para o cultivo do vírus do sarampo foi utilizada linhagem de célula sensível (B95a) (BELLINI e HELFAND, 2003).

Também foram utilizadas técnicas de biologia molecular com extração de material genético (RNA viral) das amostras clínicas, mediante realização de PCR, após transcrição reversa (RT-PCR), seqüenciamento e análise filogenética para a caracterização genotípica do vírus (BELLINI e HELFAND, 2003; WHO, 2003). 
Para o diagnóstico da rubéola foi utilizado o método imunoenzimático de captura (ELISA de captura) utilizando kit comercial Organon ou o método imunoenzimático (ELISA) com o kit comercial Behring.

Todos os casos que apresentavam anticorpos IgM contra o sarampo, foram submetidos, pelo IAL-Central, a testes de imunodiagnóstico utilizando kit comercial de ELISA de captura Biotrin para parvovírus B19 e imunofluorescência para herpes vírus 6 e/ou PCR para os dois vírus.

Em 2003, as amostras foram também processadas para dengue, pelo IAL-Central, por meio do método imunoenzimático de captura (MAC-ELISA) e/ou kit comercial Panbio. Nos demais anos, somente casos selecionados com critério clínico-epidemiológico foram processados para esse agravo.

O algoritmo de investigação laboratorial utilizado para os casos com a presença de anticorpos da classe IgM contra o sarampo está apresentado na figura 3.

Figura 3. Algoritmo de investigação etiológica utilizado para os casos com presença de anticorpos da classe IgM contra o sarampo.

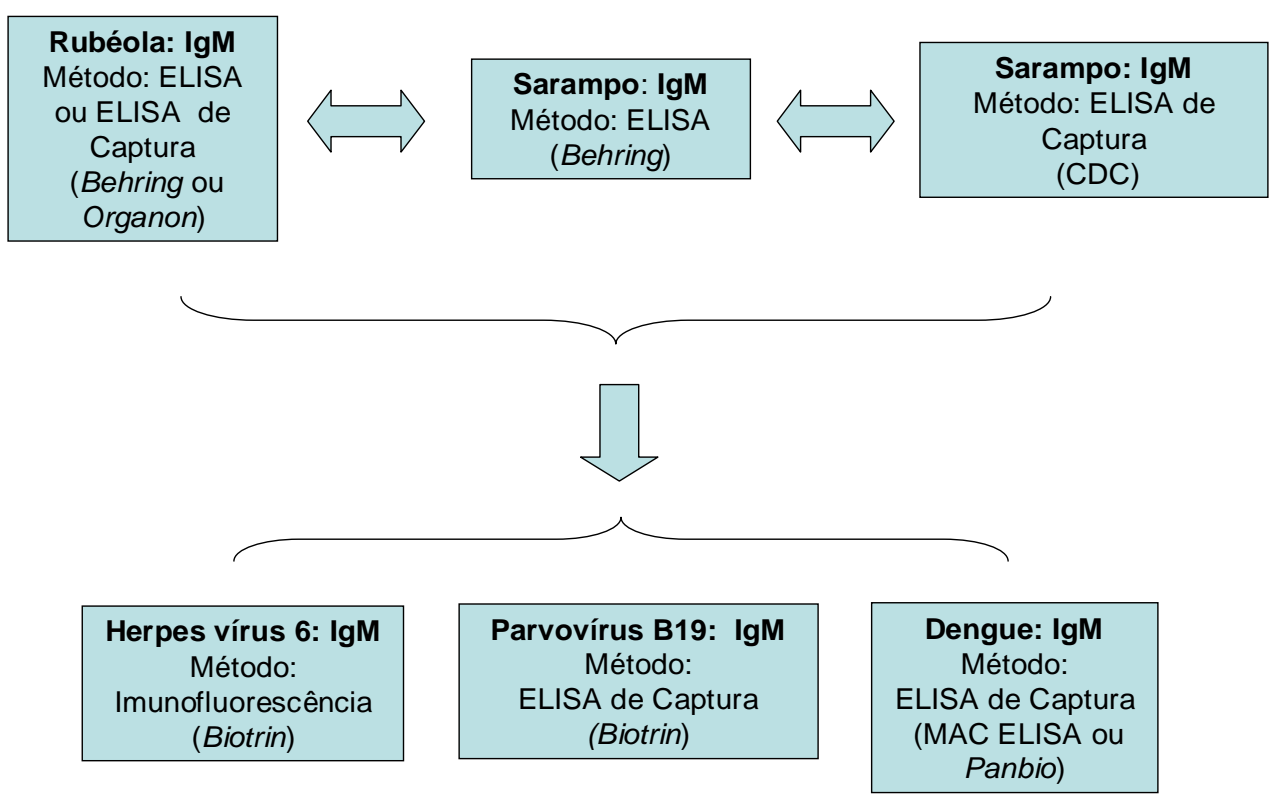




\subsection{Variáveis do estudo}

As variáveis de interesse para este estudo foram relativas ao espaço (distrito administrativo (DA), município e direção regional de saúde de residência (DIR)); ao tempo (semana epidemiológica, mês e ano dos primeiros sintomas); à pessoa (idade, sexo, situação vacinal, exposição à vacina de sarampo, contato com casos semelhantes, manifestações clínicas: exantema, febre, tosse, coriza, conjuntivite, adenopatia, manchas de Koplik, artralgia, gânglios, entre outras); aos dados laboratoriais (resultados de exames, intervalos de tempo entre: coleta e vacina, coleta e exantema).

\subsection{Criação e manejo do banco de dados}

Os bancos de dados, SINAN e IAL, foram agrupados e algumas variáveis foram incluídas com o objetivo de facilitar a consolidação e análise. Este novo banco de dados que originalmente foi elaborado no programa EPI-INFO, versão $6.4^{\circledR}$, foi convertido para o software estatístico SPSS (Statistical Package for Social Sciences), versão $15^{\circledR}$.

Foi realizada análise de consistência do banco de dados, utilizando as informações das fichas epidemiológicas e os resultados laboratoriais do IAL, para evitar os possíveis erros de digitação.

Além dessa análise, para complementar o banco de dados, foram revisados os prontuários e/ou fichas epidemiológicas de cada caso, pelo investigador, com o objetivo de confirmar as informações já existentes e recuperar os dados de variáveis sem preenchimento.

Foi elaborado um dicionário de variáveis com as respectivas categorias.

\subsection{Análise dos dados}

Para todos os anos, os casos foram analisados segundo os caracteres epidemiológicos (tempo, espaço e pessoa), aspectos clínicos e situação vacinal.

Os casos foram analisados após sua divisão em dois grupos, um deles formado por casos expostos à vacina e outro por casos não expostos 
à vacina, esse último foi subdividido em vacinados e não vacinados (HELFAND et al., 1999).

A análise descritiva foi apresentada pela sua distribuição percentual por categoria ou, se variável contínua, pelos cálculos de média e mediana. Algumas variáveis contínuas foram transformadas em variáveis categóricas. A apresentação dos dados foi efetuada mediante distribuições de freqüências nas formas de tabelas, gráficos e mapas. Para a análise comparativa das variáveis categóricas foi utilizado teste do qui-quadrado e o teste exato de Fischer.

No ano 2001, a Ficha de Investigação do SINAN foi modificada, principalmente quanto à quantidade de variáveis referentes aos dados clínicos de febre e exantema. Desta forma, a análise foi realizada somente com as variáveis presentes nos cinco anos de estudo.

\subsection{Considerações sobre ética em pesquisa}

O estudo respeitou as recomendações da Resolução $n^{\circ}$ 196, de 10 de outubro de 1996, do Conselho Nacional de Saúde para a Pesquisa Científica em Seres Humanos. O estudo foi realizado mediante análise de dados secundários referentes às informações de rotina da vigilância do sarampo e da rubéola do Centro de Vigilância Epidemiológica "Professor Alexandre Vranjac" da Coordenadoria de Controle de Doenças da Secretaria Estadual de Saúde de São Paulo, mediante permissão da instituição. Serão garantidos o anonimato dos sujeitos da pesquisa e a privacidade das informações, utilizando-se os dados exclusivamente para os propósitos deste estudo. Apresenta-se anexo o termo de compromisso (Anexo 3).

O projeto foi aprovado pelo Comitê de Ética da Faculdade de Saúde Pública da Universidade de São Paulo (USP) (Anexo 4). 


\section{RESULTADOS}

No período de 2000 a 2004, foram notificados ao sistema de vigilância no estado 45.953 casos suspeitos de doença exantemática, com uma taxa de notificação de 23 casos por 100.000 habitantes, com 11,2\% suspeitos de sarampo e $88,8 \%$ de rubéola, os quais foram submetidos a 58.309 testes de imunodiagnóstico para pesquisas de anticorpos da classe IgM contra o sarampo, pelas técnicas ELISA e/ou ELISA de captura. Desse total, 463 casos apresentaram anticorpos da classe IgM contra o sarampo e foram selecionados para este estudo com a classificação de caso possível de sarampo. Dos 463 casos, 239 (51,6\%) foram confirmados pelas técnicas de ELISA e ELISA de captura, 164 (35,4\%) somente pela primeira e 60 (13,0\%) pela segunda técnica.

Desse total, $297 / 463(64,1 \%)$ foram classificados como caso exposto à vacina, desses 167/297 casos apresentaram evento adverso pós-vacina, e $138 / 463(29,8 \%)$ como caso não exposto à vacina. Foram excluídos, dessa classificação, 28 casos com vacinação ignorada (Figura 4).

Figura 4. Total dos casos suspeitos e classificação dos casos possíveis de sarampo $^{1}$ segundo exposição à vacina do sarampo. Estado de São Paulo, 20002004.

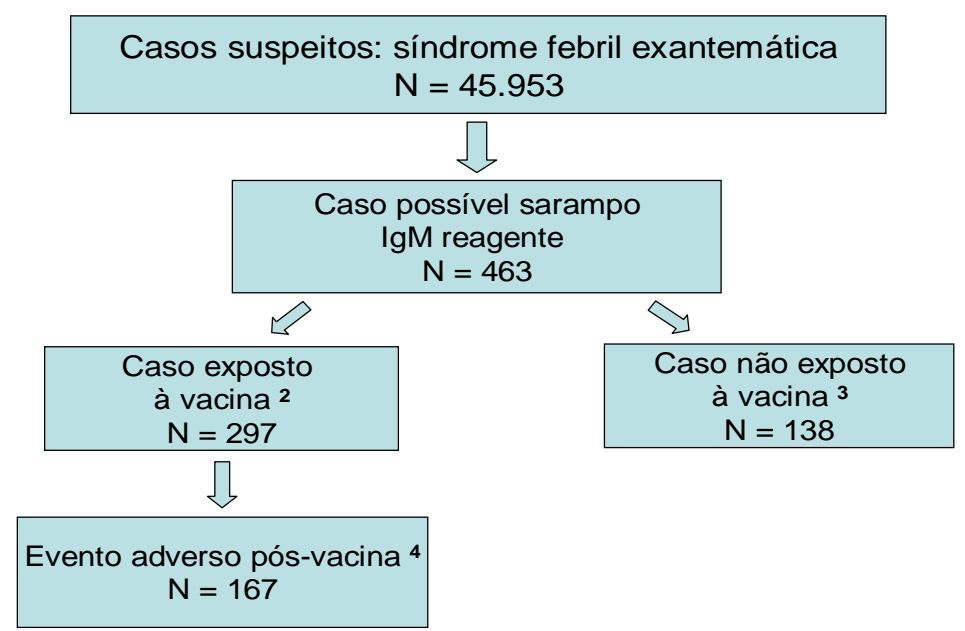

\footnotetext{
1 Pacientes com anticorpos da classe IgM contra o sarampo identificados pelas técnicas de ELISA e/ou ELISA de captura

2 Caso vacinado com coleta para diagnóstico de 8 a 56 dias da vacinação

3 Foram excluídos 28 casos com vacinação ignorada

4 Febre e/ou exantema com intervalo de 5 a 14 dias da aplicação da vacina contra o sarampo
} 
A investigação dos casos foi realizada em 417 (90,1\%) casos em até oito dias após o início do exantema, período em que habitualmente é realizado o diagnóstico do paciente. O tempo médio entre o exantema e a investigação foi de três dias e mediana de dois dias.

A coleta oportuna, preconizada pela vigilância do sarampo e da rubéola, para a identificação dos anticorpos da classe IgM contra o sarampo é de até 28 dias após o início do exantema. Esse intervalo foi observado em $448(96,8 \%)$ casos. A média e a mediana encontradas entre o início do exantema e a primeira coleta da sorologia foram de 3,9 e 2 dias, respectivamente. Não houve diferenças entre os anos de estudo.

A idade dos pacientes variou de três meses a 47 anos, com média de 4,5 anos e mediana de um ano de idade. As crianças menores de cinco anos de idade corresponderam a 80,3\% dos casos, nesse grupo a média de idade foi de 12 e a mediana de 10 meses (variando de 3 a 59 meses). Os casos com cinco anos e mais apresentaram média e mediana de 21,6 e 21,3 anos, respectivamente (Tabela 1 ).

Tabela 1. Casos possíveis de sarampo ${ }^{1}$ segundo a faixa etária. Estado de São Paulo, 2000-2004.

\begin{tabular}{lcc}
\hline \hline & \multicolumn{2}{c}{ Faixa Etária } \\
& $<\mathbf{5}$ anos (em meses) & $>=\mathbf{5}$ anos (em anos) \\
& $\mathbf{N}=\mathbf{3 7 2}$ & $\mathbf{N}=\mathbf{9 1}$ \\
\hline \hline Média & 12 & 21,6 \\
Mediana & 10 & 21,3 \\
Desvio Padrão & 0,6 & 10,9 \\
Mínima & 3 & 5,4 \\
Máxima & 59 & 47,3 \\
\hline
\end{tabular}

${ }^{1}$ Pacientes com anticorpos da classe IgM contra o sarampo identificados pelas técnicas de ELISA e/ou ELISA de captura.

A média e a mediana do número anual de casos foram de 92,6 e 79 casos, respectivamente (variando de 74 a 135). Foi encontrada maior 
proporção de indivíduos do sexo feminino $(56,6 \%)$ e a maioria dos casos $(84,4 \%)$ apresentou registro da aplicação da vacina monovalente de sarampo, tríplice viral ou dupla viral, na carteira de vacinação (Tabela 2).

Os grupos etários mais representados foram os de nove a onze meses, com 169/463 (36,5\%) e de 12 a 23 meses de idade, 152/463 (32,8\%) casos, faixas etárias preconizadas para a aplicação da primo vacinação com o componente do sarampo (Tabela 2). Até o ano 2002, a aplicação da vacina monovalente do sarampo era recomendada aos nove meses e, a partir de janeiro de 2003 passou a ser aos 12 meses de idade, com a vacina tríplice viral.

Dos 463 casos, $272(58,7 \%)$ cumpriram a definição de caso suspeito de sarampo (febre, exantema e tosse e/ou coriza e/ou conjuntivite). A clínica específica para sarampo, com apresentação de pródromos (febre), duração mínima do exantema (três dias) e da febre (dois dias), foi observada em $71 / 463(15,3 \%)$ casos.

Quanto à exposição à vacina do sarampo e à faixa etária observou-se que a maior proporção de casos expostos à vacina recentemente está na idade da primo vacinação (nove e doze meses de idade). Os casos não expostos e não vacinados $(\mathrm{N}=44)$ apresentaram as maiores proporções nos menores de nove meses $(52,3 \%)$ e nos maiores de 20 anos (29,5\%) (Tabela $3)$.

As manifestações clínicas mais freqüentes foram: exantema (97,0\%); febre $(85,3 \%)$; coriza $(48,4 \%)$ e tosse $(45,6 \%)$.

O resumo das principais manifestações clínicas e exposição à vacina do sarampo (Tabela 4) mostra que os casos não vacinados, quando comparados aos vacinados, apresentam as maiores proporções nos sinais e sintomas contemplados na definição de caso suspeito de sarampo.

A média de duração do exantema foi de 3,8 dias e a mediana de 3 dias, com variação de zero a 21 dias. O maior percentual dos casos 324/463 $(70,0 \%)$ apresentou duração do exantema entre um e cinco dias. Quanto à duração da febre, a média foi de 2,7 dias e a mediana de 2 dias (variando de zero a 30 dias). 
Tabela 2. Casos possíveis de sarampo ${ }^{1}$ segundo ano dos primeiros sintomas, sexo, idade e situação vacinal ${ }^{2}$. Estado de São Paulo, 2000-2004.

\begin{tabular}{|c|c|c|c|c|c|c|c|c|c|c|c|c|}
\hline \multirow[t]{2}{*}{ Característica } & \multicolumn{2}{|c|}{$\begin{array}{c}2000 \\
(N=78)\end{array}$} & \multicolumn{2}{|c|}{$\begin{array}{c}2001 \\
(N=135)\end{array}$} & \multicolumn{2}{|c|}{$\begin{array}{c}2002 \\
(N=79)\end{array}$} & \multicolumn{2}{|c|}{$\begin{array}{c}2003 \\
(N=74)\end{array}$} & \multicolumn{2}{|c|}{$\begin{array}{c}2004 \\
(N=97)\end{array}$} & \multicolumn{2}{|c|}{$\begin{array}{c}\text { Total } \\
(\mathrm{N}=463)\end{array}$} \\
\hline & $\mathbf{N}$ & $(\%)$ & $\mathbf{N}$ & $(\%)$ & $\mathbf{N}$ & $(\%)$ & $\mathbf{N}$ & $(\%)$ & $\mathbf{N}$ & $(\%)$ & $\mathrm{N}$ & $(\%)$ \\
\hline \multicolumn{13}{|l|}{ Sexo } \\
\hline Fem & 47 & $(60,3)$ & 72 & $(53,3)$ & 47 & $(59,5)$ & 43 & $(58,1)$ & 53 & $(54,6)$ & 262 & $(56,6)$ \\
\hline Masc & 31 & $(39,7)$ & 63 & $(46,7)$ & 32 & $(40,5)$ & 31 & $(41,9)$ & 44 & $(45,4)$ & 201 & $(43,4)$ \\
\hline Total & 78( & $100,0)$ & 135( & $(100,0)$ & 79 & $100,0)$ & 74(1) & $100,0)$ & 97( & $(100,0)$ & 463( & $(100,0)$ \\
\hline \multicolumn{13}{|c|}{ Idade (em meses e anos) } \\
\hline$=<6 \mathrm{~m}$ & & $(3,8)$ & 7 & $(5,2)$ & 5 & $(6,3)$ & 2 & $(2,7)$ & 1 & $(1,0)$ & 18 & $(3,9)$ \\
\hline $7-8 m$ & 2 & $(2,6)$ & 4 & $(3,0)$ & 0 & $(0,0)$ & 3 & $(4,0)$ & 1 & $(1,0)$ & 10 & $(2,2)$ \\
\hline $9-11 m$ & 50 & $(64,2)$ & & $(50,4)$ & 46 & $(58,2)$ & 3 & $(4,0)$ & 2 & $(2,1)$ & 169 & $(36,5)$ \\
\hline $12-23 m$ & 6 & $(7,7)$ & 16 & $(11,8)$ & 6 & $(7,6)$ & 56 & $(75,7)$ & & $(70,1)$ & 152 & $(32,8)$ \\
\hline $2-4 a$ & 3 & $(3,8)$ & 0 & $(0,0)$ & 7 & $(8,9)$ & 4 & $(5,4)$ & 9 & $(9,3)$ & 23 & $(5,0)$ \\
\hline $5-9 a$ & 3 & $(3,8)$ & 5 & $(3,7)$ & 3 & $(3,8)$ & 3 & $(4,0)$ & 5 & $(5,1)$ & 19 & $(4,1)$ \\
\hline $10-14 a$ & 0 & $(0,0)$ & 7 & $(5,2)$ & 2 & $(2,5)$ & 0 & $(0,0)$ & 1 & $(1,0)$ & 10 & $(2,1)$ \\
\hline $15-19 a$ & 3 & $(3,8)$ & 5 & $(3,7)$ & 3 & $(3,8)$ & 0 & $(0,0)$ & 2 & $(2,1)$ & 13 & $(2,8)$ \\
\hline $20-29 a$ & & 10,3) & 14 & $(10,4)$ & 4 & $(5,1)$ & 1 & $(1,4)$ & 3 & $(3,1)$ & 30 & $(6,5)$ \\
\hline $30-39 a$ & 0 & $(0,0)$ & 6 & $(4,4)$ & 3 & $(3,8)$ & 1 & $(1,4)$ & 3 & $(3,1)$ & 13 & $(2,8)$ \\
\hline$>=40 \mathrm{a}$ & 0 & $(0,0)$ & 3 & $(2,2)$ & 0 & $(0,0)$ & 1 & $(1,4)$ & 2 & $(2,1)$ & 6 & $(1,3)$ \\
\hline Total & 78( & $100,0)$ & 135( & $(100,0)$ & 79 ( & $(100,0)$ & 74(1 & $100,0)$ & 97( & $(100,0)$ & 463( & $(100,0)$ \\
\hline
\end{tabular}

Situação Vacinal (em meses)

Vacinado

\begin{tabular}{lcccccc}
$<12 \mathrm{~m}$ & $52(76,5)$ & $68(67,3)$ & $45(65,2)$ & $2(3,1)$ & $1(1,1)$ & $168(43,0)$ \\
$>=12 \mathrm{~m}$ & $16(23,5)$ & $33(32,7)$ & $24(34,8)$ & $62(96,9)$ & $88(98,9)$ & $223(57,0)$ \\
Total & $\mathbf{6 8 ( 1 0 0 , 0 )}$ & $\mathbf{1 0 1 ( 1 0 0 , 0 )}$ & $\mathbf{6 9 ( 1 0 0 , 0 )}$ & $\mathbf{6 4 ( 1 0 0 , 0 )}$ & $\mathbf{8 9 ( 1 0 0 , 0 )}$ & $\mathbf{3 9 1}(\mathbf{1 0 0 , 0 )}$ \\
Não vacinado & & & & & & \\
$<12 \mathrm{~m}$ & $3(75,0)$ & $11(57,9)$ & $6(66,7)$ & $5(62,5)$ & $3(75,0)$ & $28(63,6)$ \\
$>=12 \mathrm{~m}$ & $1(25,0)$ & $8(42,1)$ & $3(33,3)$ & $3(37,5)$ & $1(25,0)$ & $16(36,4)$ \\
Total & $\mathbf{4 1 0 0 , 0 )}$ & $\mathbf{1 9 ( 1 0 0 , 0 )}$ & $\mathbf{9 ( 1 0 0 , 0 )}$ & $\mathbf{8 ( 1 0 0 , 0 )}$ & $\mathbf{4 ( 1 0 0 , 0 )}$ & $\mathbf{4 4 ( 1 0 0 , 0 )}$ \\
lgnorado & & & & & & \\
$<12 \mathrm{~m}$ & $0(0,0)$ & $0(0,0)$ & $0(0,0)$ & $1(50,0)$ & $0(0,0)$ & $1(3,6)$ \\
$>=12 \mathrm{~m}$ & $6(100,0)$ & $15(100,0)$ & $1(100,0)$ & $1(50,0)$ & $4(100,0)$ & $27(96,4)$ \\
Total & $\mathbf{6 ( 1 0 0 , 0 )}$ & $\mathbf{1 5 ( 1 0 0 , 0 )}$ & $\mathbf{1 ( 1 0 0 , 0 )}$ & $\mathbf{2 ( 1 0 0 , 0 )}$ & $\mathbf{4 ( 1 0 0 , 0 )}$ & $\mathbf{2 8 ( 1 0 0 , 0 )}$ \\
\hline
\end{tabular}

${ }^{1}$ Pacientes com anticorpos da classe IgM contra o sarampo identificados pelas técnicas de ELISA e/ou ELISA de captura

${ }^{2}$ Até o ano 2002, a aplicação da vacina monovalente do sarampo era recomendada aos nove meses e, a partir de janeiro de 2003, passou a ser aos 12 meses de idade, com a vacina tríplice viral 
Tabela 3. Casos possíveis de sarampo ${ }^{1}$ segundo exposição à vacina do sarampo ${ }^{2,3}$ e características. Estado de São Paulo, 2000-2004.

\begin{tabular}{|c|c|c|c|c|}
\hline \multirow[t]{3}{*}{ Característica } & \multicolumn{2}{|c|}{ Não exposto } & \multirow{3}{*}{$\begin{array}{l}\text { Exposto } \\
\begin{array}{l}N=297 \\
N \quad(\%)\end{array}\end{array}$} & \multirow{3}{*}{$\begin{array}{l}\text { Total } \\
\begin{aligned} \mathrm{N}=435^{3} \\
\mathrm{~N}(\%)\end{aligned}\end{array}$} \\
\hline & $\begin{array}{l}\text { Não vacinado } \\
\qquad=44\end{array}$ & $\begin{array}{c}\text { Vacinado } \\
N=94\end{array}$ & & \\
\hline & $\mathrm{N}(\%)$ & $\mathrm{N}(\%)$ & & \\
\hline \multicolumn{5}{|l|}{ Sexo } \\
\hline Fem & $25(56,8)$ & $57(60,6)$ & $162(54,5)$ & $244(56,1)$ \\
\hline Masc & $19(43,2)$ & $37(39,4)$ & $135(45,5)$ & $191(43,9)$ \\
\hline \multicolumn{5}{|c|}{ Faixa etária (em meses e anos) } \\
\hline$<9 \mathrm{~m}$ & $23(52,3)$ & $2(2,1)$ & $3(1,0)$ & $28(6,4)$ \\
\hline $9-11 m$ & $5(11,4)$ & $7(7,5)$ & $156(52,5)$ & $168(38,6)$ \\
\hline $12-23 m$ & $0(0,0)$ & $16(17,0)$ & $133(44,8)$ & $149(34,3)$ \\
\hline $2-4 a$ & $1(2,3)$ & $20(21,3)$ & $2(0,7)$ & $23(5,3)$ \\
\hline $5-9 a$ & $0(0,0)$ & $16(17,0)$ & $0(0,0)$ & $16(3,7)$ \\
\hline $10-14 a$ & $0(0,0)$ & $10(10,6)$ & $0(0,0)$ & $10(2,3)$ \\
\hline $15-19 a$ & $2(4,5)$ & $6(6,4)$ & $0(0,0)$ & $8(1,8)$ \\
\hline $20-29 a$ & $6(13,6)$ & $10(10,6)$ & $3(1,0)$ & $19(4,4)$ \\
\hline$>=30 \mathrm{a}$ & $7(15,9)$ & $7(7,5)$ & $0(0,0)$ & $14(3,2)$ \\
\hline \multicolumn{5}{|c|}{ Caso suspeito de sarampo ${ }^{4}$} \\
\hline Não & $13(29,5)$ & $44(46,8)$ & $112(37,7)$ & $169(38,9)$ \\
\hline Sim & $31(70,5)$ & $49(52,1)$ & $179(60,3)$ & $259(59,5)$ \\
\hline Outras exantemáticas & $0(0,0)$ & $1(1,1)$ & $6(2,0)$ & $7(1,6)$ \\
\hline \multicolumn{5}{|l|}{ Clínica específica $^{5}$} \\
\hline Não & $31(70,4)$ & $76(80,8)$ & $244(82,1)$ & $351(80,7)$ \\
\hline Sim & $12(27,3)$ & $17(18,1)$ & $38(12,8)$ & $67(15,4)$ \\
\hline Ignorado & $1(2,3)$ & $1(1,1)$ & $15(5,1)$ & $17(3,9)$ \\
\hline \multicolumn{5}{|c|}{$\begin{array}{l}{ }^{1} \text { Pacientes com anticorpos da classe IgM contra o sarampo identificados pelas técnicas de } \\
\text { ELISA e/ou ELISA de captura. } \\
{ }^{2} \text { Caso exposto à vacina: caso vacinado e coleta para diagnóstico de } 8 \text { a } 56 \text { dias } \\
\text { da vacinação } \\
{ }^{3} \text { Foram excluídos } 28 \text { casos com vacinação ignorada } \\
{ }^{4} \text { Caso suspeito de sarampo: febre, exantema e tosse e/ou coriza e/ou conjuntivite } \\
{ }^{5} \text { Clínica específica de sarampo: caso suspeito e febre maior que dois dias e anterior ao } \\
\text { exantema, este com duração maior que dois dias }\end{array}$} \\
\hline
\end{tabular}


Tabela 4. Casos possíveis de sarampo ${ }^{1}$ segundo manifestações clínicas e exposição à vacina do sarampo ${ }^{2,3}$. Estado de São Paulo, 2000-2004.

\begin{tabular}{|c|c|c|c|c|}
\hline \multirow{3}{*}{$\begin{array}{l}\text { Manifestação } \\
\text { Clínica }\end{array}$} & \multicolumn{2}{|c|}{ Não exposto } & \multirow{3}{*}{$\begin{array}{l}\text { Exposto } \\
\begin{aligned} N=297 \\
N \quad(\%)\end{aligned}\end{array}$} & \multirow{3}{*}{$\begin{array}{l}\text { Total } \\
\begin{array}{l}\mathrm{N}=435^{3} \\
\mathrm{~N}(\%)\end{array}\end{array}$} \\
\hline & $\begin{array}{c}\text { Não } \\
\text { vacinado } \\
N=44\end{array}$ & $\begin{array}{c}\text { Vacinado } \\
N=94\end{array}$ & & \\
\hline & N (\%) & N (\%) & & \\
\hline \multicolumn{5}{|l|}{ Exantema $^{4}$} \\
\hline Não & $0(0,0)$ & $3(3,2)$ & $6(2,0)$ & $9(2,1)$ \\
\hline Sim & $44(100,0)$ & $91(96,8)$ & $291(98,0)$ & $426(97,9)$ \\
\hline Ignorado & $0(0,0)$ & $0(0,0)$ & $0(0,0)$ & $0(0,0)$ \\
\hline \multicolumn{5}{|l|}{ Febre $^{5}$} \\
\hline Não & $3(6,8)$ & $19(20,2)$ & $34(11,4)$ & $56(12,9)$ \\
\hline Sim & $41(93,2)$ & $74(78,7)$ & $260(87,6)$ & $375(86,2)$ \\
\hline Ignorado & $0(0,0)$ & $1(1,1)$ & $3(1,0)$ & $4(0,9)$ \\
\hline \multicolumn{5}{|l|}{ Tosse } \\
\hline Não & $20(45,5)$ & $60(63,8)$ & $146(49,2)$ & $226(52,0)$ \\
\hline Sim & $24(54,5)$ & $33(35,1)$ & $147(49,5)$ & $204(46,9)$ \\
\hline Ignorado & $0(0,0)$ & $1(1,1)$ & $4(1,3)$ & $5(1,1)$ \\
\hline \multicolumn{5}{|l|}{ Conjuntivite } \\
\hline Não & $33(75,0)$ & $76(80,8)$ & $246(82,8)$ & $355(81,6)$ \\
\hline Sim & $11(25,0)$ & $17(18,1)$ & $44(14,8)$ & $72(16,6)$ \\
\hline Ignorado & $0(0,0)$ & $1(1,1)$ & $7(2,4)$ & $8(1,8)$ \\
\hline \multicolumn{5}{|l|}{ Coriza } \\
\hline Não & $20(45,5)$ & $51(54,2)$ & $142(47,8)$ & $213(48,9)$ \\
\hline Sim & $24(54,5)$ & $42(44,7)$ & $150(50,5)$ & $216(49,7)$ \\
\hline Ignorado & $0(0,0)$ & $1(1,1)$ & $5(1,7)$ & $6(1,4)$ \\
\hline \multicolumn{5}{|l|}{ Koplik } \\
\hline Não & $38(86,4)$ & $74(78,7)$ & $245(82,5)$ & $357(82,1)$ \\
\hline Sim & $2(4,5)$ & $4(4,3)$ & $8(2,7)$ & $14(3,2)$ \\
\hline Ignorado & $4(9,1)$ & $16(17,0)$ & $44(14,8)$ & $64(14,7)$ \\
\hline \multicolumn{5}{|l|}{ Gânglios } \\
\hline Não & $27(61,4)$ & $48(51,0)$ & $152(51,2)$ & $227(52,2)$ \\
\hline Sim & $15(34,1)$ & $37(39,4)$ & $123(41,4)$ & $175(40,2)$ \\
\hline Ignorado & $2(4,5)$ & $9(9,6)$ & $22(7,4)$ & $33(7,6)$ \\
\hline \multicolumn{5}{|l|}{ Artrite } \\
\hline Não & $27(61,3)$ & $67(71,3)$ & $220(74,1)$ & $314(72,2)$ \\
\hline Sim & $9(20,5)$ & $23(24,5)$ & $9(3,0)$ & $41(9,4)$ \\
\hline Ignorado & $8(18,2)$ & $4(4,2)$ & $68(22,9)$ & $80(18,4)$ \\
\hline \multicolumn{5}{|c|}{ Dor retro-ocular } \\
\hline Não & $30(68,2)$ & $65(69,1)$ & $213(71,7)$ & $308(70,8)$ \\
\hline Sim & $3(6,8)$ & $17(18,1)$ & $5(1,7)$ & $25(5,7)$ \\
\hline Ignorado & $11(25,0)$ & $12(12,8)$ & $79(26,6)$ & $102(23,5)$ \\
\hline $\begin{array}{l}\text { Caso exposto à } \\
\text { da vacinação } \\
\text { Foram excluídos } \\
\text { Duração do exal }\end{array}$ & com vacina & gnorada & o identifica & a 56 dias \\
\hline
\end{tabular}


A maioria dos pacientes não apresentou complicações e entre os pacientes que apresentaram o maior percentual ocorreu nos casos não expostos à vacina (Tabela 5). A diarréia foi a única complicação que apresentou diferença estatisticamente significante $(p<0,05)$, entre os três grupos. As hospitalizações foram necessárias em quatro $(0,9 \%)$ casos com as hipóteses diagnósticas de: desidratação, escarlatina, infecção respiratória aguda e pneumonia. Os quatro casos hospitalizados residiam em diferentes municípios; ocorreram em 2000, 2002 e 2004; apenas um caso era vacinado e apresentavam as seguintes idades: quatro e dez meses e 23 e 47 anos.

Tabela 5. Casos possíveis de sarampo $^{1}$ segundo principais complicações e exposição à vacina do sarampo ${ }^{2,3}$. Estado de São Paulo, 2000-2004.

\begin{tabular}{|c|c|c|c|c|c|}
\hline \multirow[t]{2}{*}{ Complicação } & $\begin{array}{c}\text { Não } \\
\text { Não } \\
\text { vacinado } \\
\mathrm{N}=\mathbf{4 4}\end{array}$ & $\begin{array}{l}\text { Vasto } \\
\text { Vacinado } \\
\mathrm{N}=94\end{array}$ & Exposto & $N=435^{3}$ & \multirow[t]{2}{*}{$\begin{array}{c}\text { Valor de } \\
p\end{array}$} \\
\hline & $\mathrm{N} \quad(\%)$ & $\mathrm{N} \quad(\%)$ & $\mathrm{N} \quad(\%)$ & $\mathrm{N} \quad(\%)$ & \\
\hline Diarréia & & & & & $<0,05^{4}$ \\
\hline Não & $37(84,1)$ & $83(89,2)$ & $269(93,4)$ & $389(91,5)$ & \\
\hline Sim & $7(15,9)$ & $10(10,8)$ & $19(6,6)$ & $36(8,5)$ & \\
\hline Total & $44(100,0)$ & $93(100,0)$ & $288(100,0)$ & $425(100,0)$ & \\
\hline Otite & & & & & $>0,05^{4}$ \\
\hline Não & $39(88,6)$ & $85(91,4)$ & $273(95,1)$ & $397(93,6)$ & \\
\hline Sim & $5(11,4)$ & $8(8,6)$ & $14(4,9)$ & $27(6,4)$ & \\
\hline Total & $44(100,0)$ & $93(100,0)$ & $287(100,0)$ & $424(100,0)$ & \\
\hline Pneumonia & & & & & $>0,05^{5}$ \\
\hline Não & $43(97,7)$ & $90(98,9)$ & $285(99,3)$ & $418(99,1)$ & \\
\hline Sim & $1(2,3)$ & $1(1,1)$ & $2(0,7)$ & $4(0,9)$ & \\
\hline Total & $44(100,0)$ & $91(100,0)$ & $287(100,0)$ & $422(100,0)$ & \\
\hline $\begin{array}{l}{ }^{1} \text { Pacientes con } \\
\text { de ELISA e/ou } \\
{ }^{2} \text { Caso expost } \\
\text { da vacinação } \\
{ }^{3} \text { Foram excluíc } \\
{ }^{4} \text { Teste do qui- } \\
5 \text { Teste exato o }\end{array}$ & $\begin{array}{l}\text { ticorpos da } \\
\text { ISA de capt } \\
\text { vacina: cas } \\
28 \text { casos co } \\
\text { drado } \\
\text { isher }\end{array}$ & $\begin{array}{l}\text { sse IgM cont } \\
\text { acinado e co } \\
\text { /acinação ig }\end{array}$ & $\begin{array}{l}\text { o sarampo id } \\
\text { a para diagnc } \\
\text { ada }\end{array}$ & $\begin{array}{l}\text { itificados pela } \\
\text { ico de } 8 \text { a } 56\end{array}$ & $\begin{array}{l}\text { técnicas } \\
\text { lias }\end{array}$ \\
\hline
\end{tabular}

Dos casos investigados, $401 / 463$ (86,6\%) afirmaram não ter tido contato com casos semelhantes a sarampo e/ou rubéola nos 23 dias que 
antecederam o início dos sinais e sintomas. Somente 25/463 (5,4\%) referiram contato com caso semelhante (Tabela 6).

Tabela 6. Casos possíveis de sarampo ${ }^{1}$ que referiram contato com casos semelhantes a sarampo e/ou rubéola segundo faixa etária e sexo. Estado de São Paulo, 2000-2004.

\begin{tabular}{|c|c|c|c|}
\hline \multirow[t]{2}{*}{ Faixa Etária } & \multicolumn{2}{|c|}{ Sexo } & \multirow[t]{2}{*}{ Total } \\
\hline & Fem & Masc & \\
\hline \multicolumn{4}{|l|}{ (em meses) } \\
\hline 7 - 8 m & $1(100,0)$ & $0(0,0)$ & $1(100,0)$ \\
\hline $9-11 m$ & $3(37,5)$ & $5(62,5)$ & $8(100,0)$ \\
\hline $\begin{array}{l}12-23 \text { m } \\
\text { (em anos) }\end{array}$ & $2(66,7)$ & $1(33,3)$ & $3(100,0)$ \\
\hline $2-4 a$ & $3(75,0)$ & $1(25,0)$ & $4(100,0)$ \\
\hline $5-9 a$ & $1(50,0)$ & $1(50,0)$ & $2(100,0)$ \\
\hline $10-14 a$ & $1(100,0)$ & $0(0,0)$ & $1(100,0)$ \\
\hline $20-29 a$ & $3(75,0)$ & $1(25,0)$ & $4(100,0)$ \\
\hline $30-39 a$ & $2(100,0)$ & $0(0,0)$ & $2(100,0)$ \\
\hline Total & $16(64,0)$ & $9(36,0)$ & $25(100,0)$ \\
\hline
\end{tabular}

Considerando a relevância, para este estudo, dos grupos etários dos menores de nove meses ou com 10 anos e mais de idade, que corresponderam a 100/463 (21,6\%) casos, optou-se por apresentar uma análise detalhada dos mesmos.

Desses casos, 82/100 (82,0\%) tiveram como suspeita inicial a rubéola, 21,0\% apresentaram clínica específica para sarampo e 6,0\% dos casos foram expostos à vacina. Esses casos distribuíram-se em 42 municípios, dos quais 39,0\% (39/100) estavam localizados no município de São Paulo, distribuídos em 32 distritos administrativos. O ano 2001 concentrou 46,0\% dos casos, desses 19/46 (41,3\%) distribuíram-se de forma dispersa na capital, com somente dois casos residindo no mesmo distrito.

A distribuição segundo sexo, idade e exposição à vacina do sarampo (Tabela 7) mostra que $59,0 \%$ dos casos são do sexo feminino, apresentando 
claro predomínio do sexo feminino entre os maiores de 15 anos de idade. Quando o grupo dos menores de 15 anos e os maiores de 15 anos de idade foram comparados, em relação ao sexo, houve diferença estatisticamente significante pelo teste do qui-quadrado $(p<0,05)$. Não foi identificado nenhum vínculo entre os casos.

Dos 100 casos, 67,0\% também apresentaram anticorpos da classe IgM contra outros vírus: parvovírus B19 (27,0\%), rubéola $(20,0 \%)$, herpes vírus 6 (15,0\%), dengue (5,0\%). Dos 33/100 casos que apresentaram anticorpos somente contra o sarampo, sete casos apresentaram clínica específica para sarampo. Apenas um caso teve contato com um paciente com sarampo, no Japão, e foi confirmado como caso importado.

Tabela 7. Casos possíveis de sarampo ${ }^{1}$ entre menores de nove meses ou com dez anos e mais segundo sexo e faixa etária. Estado de São Paulo, 2000-2004.

\begin{tabular}{|c|c|c|c|}
\hline \multirow[t]{2}{*}{ Faixa etária } & \multicolumn{2}{|c|}{ Sexo } & \multirow[t]{2}{*}{ Total } \\
\hline & Fem & Masc & \\
\hline \multicolumn{4}{|l|}{ (em meses) } \\
\hline$=<6 \mathrm{~m}$ & $10(55,6)$ & $8(44,4)$ & $18(100,0)$ \\
\hline $\begin{array}{l}\mathbf{7} \text { - } 8 \text { m } \\
\text { (em anos) }\end{array}$ & $4(40,0)$ & $6(60,0)$ & $10(100,0)$ \\
\hline $10-14 a$ & $3(30,0)$ & $7(70,0)$ & $10(100,0)$ \\
\hline $15-19 a$ & $9(69,2)$ & $4(30,8)$ & $13(100,0)$ \\
\hline $20-29 a$ & $19(63,3)$ & $11(36,7)$ & $30(100,0)$ \\
\hline $30-39 a$ & $11(84,6)$ & $2(15,4)$ & $13(100,0)$ \\
\hline$>=40 \mathrm{a}$ & $3(50,0)$ & $3(50,0)$ & $6(100,0)$ \\
\hline Total & $59(59,0)$ & $41(41,0)$ & $100(100,0)$ \\
\hline
\end{tabular}

A distribuição temporal da totalidade dos pacientes mostrou que os casos distribuíram-se em todos os meses dos cinco anos de estudo, com 
maior proporção entre setembro a novembro (47 a 59 casos), representando $35,2 \%$ do total, caracterizando uma clara variação sazonal. A média e a mediana dos casos por mês foram de 38,5 e 36 casos, respectivamente.

A distribuição dos casos no tempo, segundo o mês dos primeiros sintomas (Figura 5) mostra o predomínio nas faixas etárias de nove a onze meses e dos maiores de 60 meses entre 2000 e 2002, com aumento em 2001. A partir de 2003, é nítido o predomínio do grupo de 12 a 15 meses, coincidindo com a mudança do esquema de vacinação. Em 2001, o incremento de casos entre os maiores de 60 meses foi às custas do aumento de casos na região da grande São Paulo.

A distribuição temporal dos casos segundo a semana epidemiológica (SE) (Figura 6) mostra sete semanas com mais de cinco casos; em 2001 e 2003 verifica-se três semanas em cada ano e em 2002 uma semana.

Observa-se (Figuras 5 e 6) um incremento de casos de junho de 2001 a março de 2002, com 126 casos (27,2\%) distribuídos em vários municípios do estado, com maior número no município de São Paulo 52/126 (41,3\%). Dos casos da capital, apenas dois estavam localizados no mesmo distrito administrativo (Artur Alvim), distribuídos em meses diferentes. Dos 126 casos, somente 19 (15,1\%) não eram vacinados contra o sarampo e destes, 10/19 (52,6\%) casos apresentaram também anticorpos da classe IgM e/ou PCR positivo para outra doença exantemática (eritema infeccioso, rubéola, exantema súbito) e um caso foi confirmado, em junho de 2001, como sarampo importado do Japão. 
Figura 5. Casos possíveis de sarampo ${ }^{1}$ distribuídos mês a mês segundo a faixa etária e a data dos primeiros sintomas. Estado de São Paulo, 2000-2004.

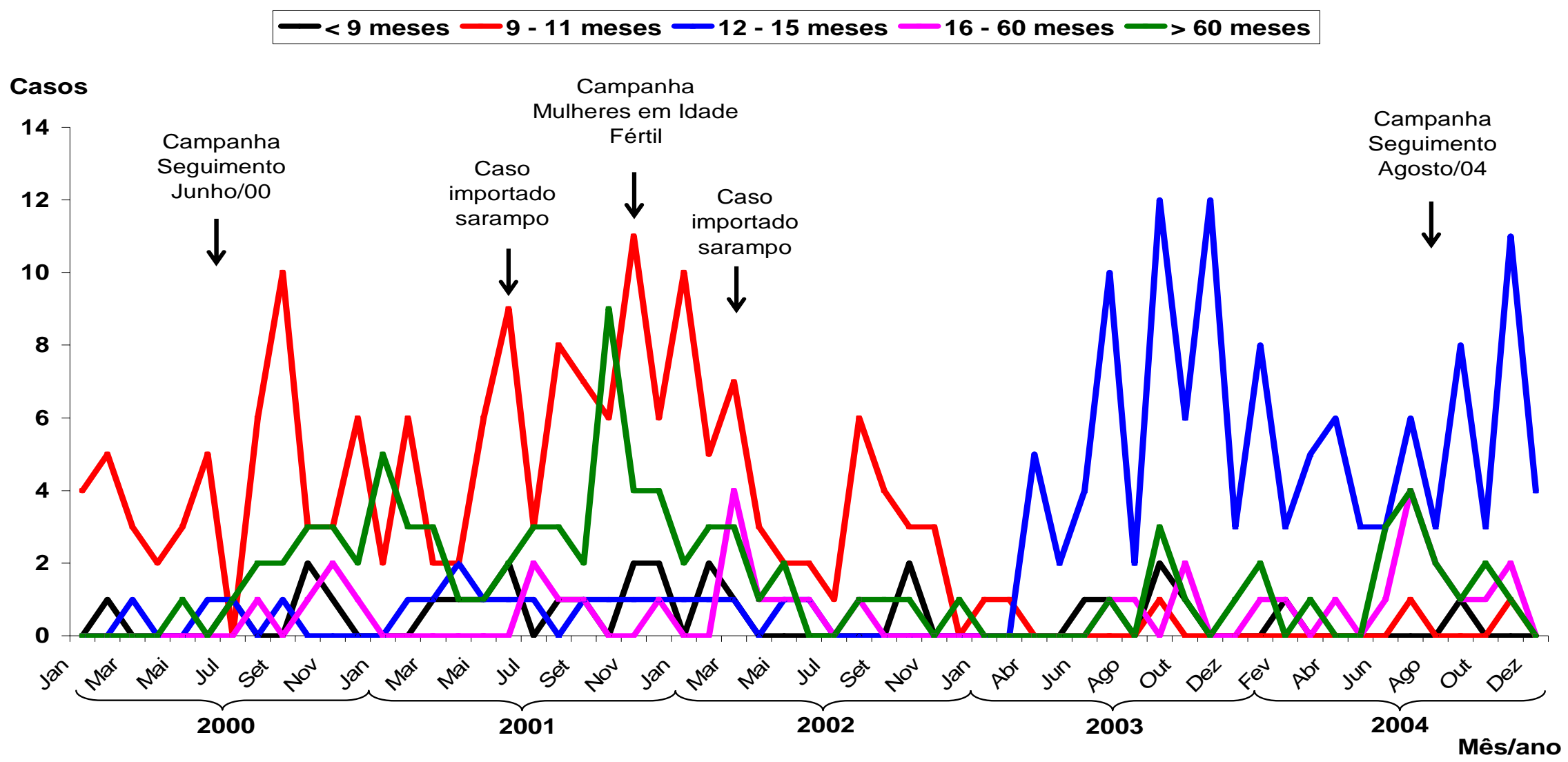

${ }^{1}$ Pacientes com anticorpos da classe IgM contra o sarampo identificados pelas técnicas de ELISA e/ou ELISA de captura 
Figura 6. Casos possíveis de sarampo ${ }^{1}$ segundo a semana epidemiológica (SE) e o ano dos primeiros sintomas. Estado de São Paulo, 2000-2004.

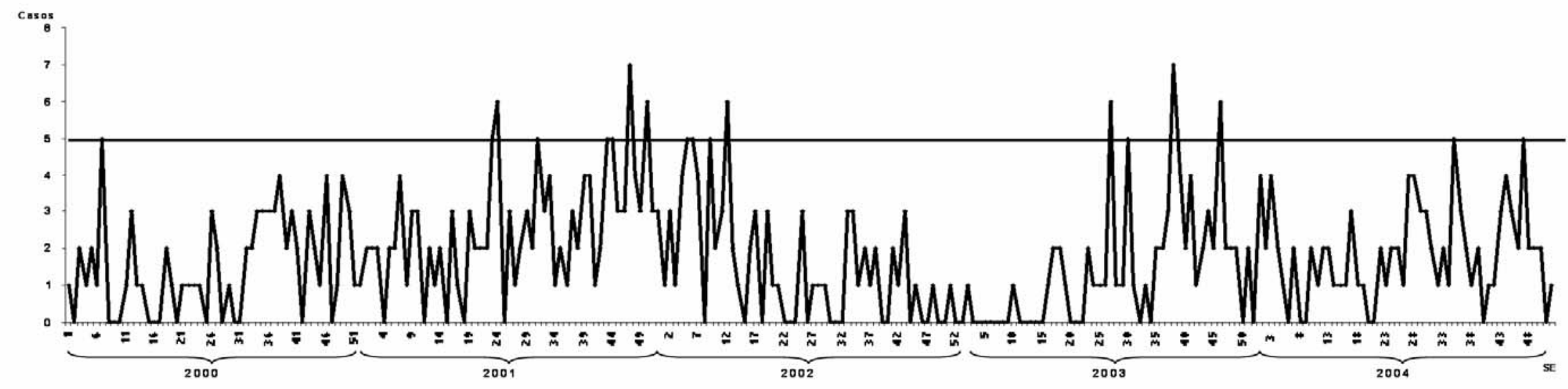

${ }^{1}$ Pacientes com anticorpos da classe IgM contra o sarampo identificados pelas técnicas de ELISA e/ou ELISA de captura 
Foram realizadas campanhas de vacinação de seguimento ${ }^{1}$ contra o sarampo, com vacina dupla e tríplice viral, respectivamente, em junho de 2000 e em agosto de 2004, alcançando mais de 92\% de cobertura vacinal. Em novembro de 2001 foi realizada vacinação em massa contra a rubéola para as mulheres em idade fértil, de 15 a 29 anos de idade, com a vacina dupla viral, atingindo mais de $90 \%$ de cobertura vacinal. Em todos os anos do estudo, também foram realizadas campanhas contra a poliomielite, em junho e agosto, quando é recomendada a aplicação das outras vacinas que se encontram em atraso.

Quanto ao ano dos primeiros sintomas, a maioria dos casos, 135/463 (29,2\%), ocorreu em 2001 com 41/135 (30,4\%) e 40/135 (29,6\%) casos aos nove meses de idade e nos maiores de cinco anos, respectivamente. A grande proporção de pacientes concentrou-se no município de São Paulo, 53/135 (39,3\%) casos distribuídos em 37 diferentes DA da capital, não apresentando nenhum agregado de casos conhecidos. Com exceção da DIR I (município de São Paulo), as duas regionais com maior freqüência de casos foram a DIR II (Santo André) com dez casos (7,4\%) e DIR III (Mogi das Cruzes) com nove casos (6,7\%), distribuídos em diversos municípios de suas áreas de abrangência. Houve um caso confirmado de sarampo importado do Japão em junho de 2001, no município de São Paulo, e a partir desse mês, com exceção de julho, houve um aumento de casos até dezembro, com média e mediana de 16 e 14 casos, respectivamente.

Somente no mês de julho de 2001, a taxa de incidência (por 100.000 habitantes) do interior do estado foi superior à incidência verificada na região da grande São Paulo (Figura 7).

\footnotetext{
${ }^{1}$ Vacinação indiscriminada dos menores de cinco anos de idade.
} 
Figura 7. Taxa de incidência (por 100.000 habitantes) dos casos possíveis de sarampo ${ }^{1}$ segundo região do estado e mês dos primeiros sintomas. Estado de São Paulo, 2001.

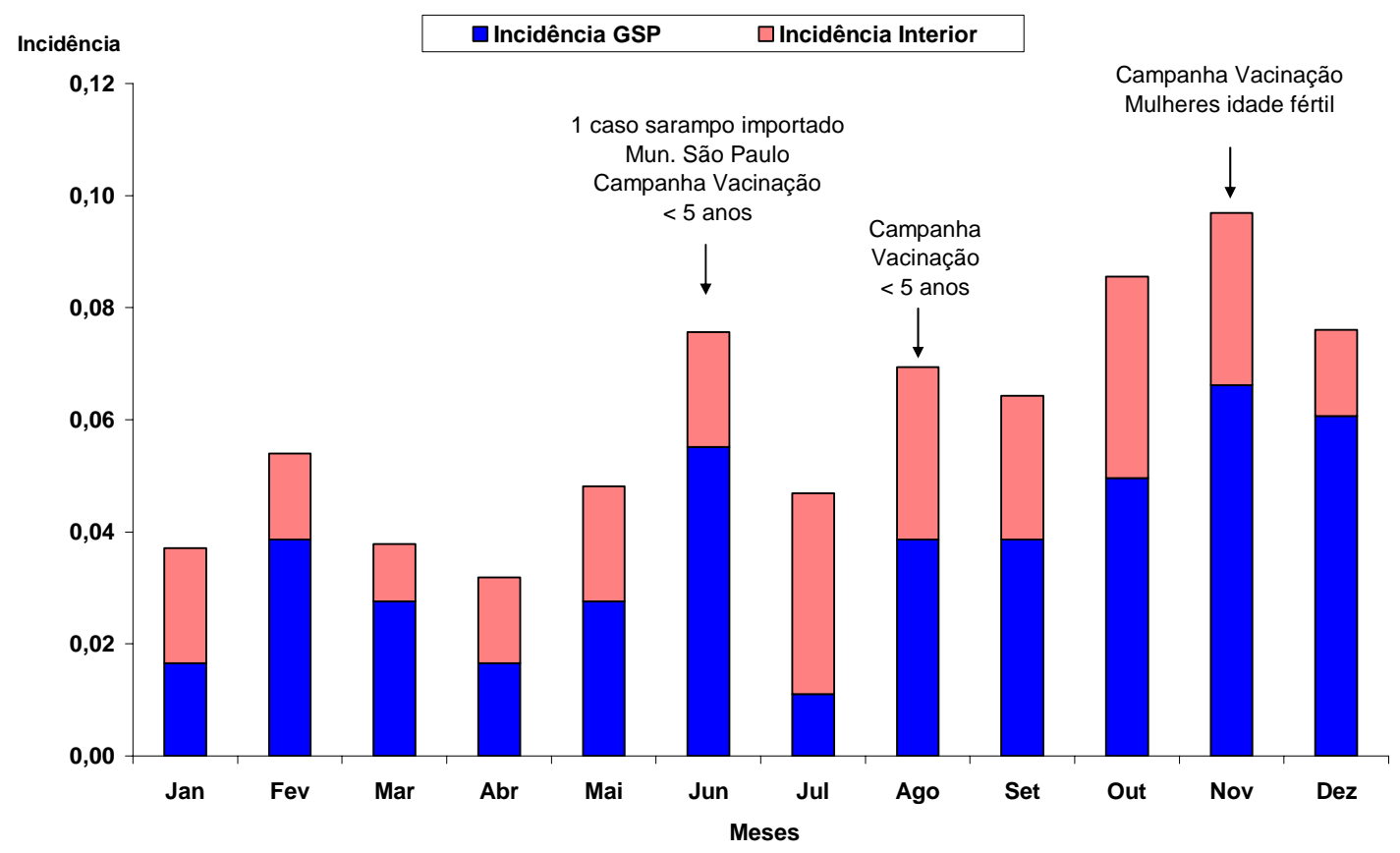

${ }^{1}$ Pacientes com anticorpos da classe IgM contra o sarampo identificados pelas técnicas de ELISA e/ou ELISA de captura

Em 2001, foi realizado busca ativa de 41 casos residentes em diversos municípios do estado, com quadro clínico altamente suspeito de sarampo. Nesses casos, além dos procedimentos de rotina, foram coletadas amostras de sangue e urina para o isolamento viral e teste de PCR para detecção do vírus do sarampo. Dos 41 casos, $26(63,4 \%)$ apresentaram anticorpos da classe IgM contra o sarampo e estão incluídos neste estudo. Em 18/26 (69,2\%) casos as amostras para o isolamento viral foram coletadas com um intervalo superior a seis dias após o início do exantema.

Esses testes foram processados pelo IAL-Central com resultados negativos, com exceção do caso de sarampo importado do Japão. Nesse caso foi isolado o vírus do sarampo. De acordo com o seqüenciamento gênico, o vírus foi classificado como pertencente ao grupo D, segundo a classificação na nomenclatura da OMS para genótipos de vírus do sarampo selvagem (WHO, 2003). 
Quanto à distribuição espacial, as regionais mais representadas, nos cinco anos de estudo, foram: DIR I - município de São Paulo: 173/463 casos (37,4\%); DIR XII - Campinas: 50/463 casos (10,8\%); DIR V - Osasco: 34/463 casos (7,3\%) e DIR II - Santo André: 29/463 casos (6,3\%).

Somente três regionais não registraram casos possíveis de sarampo no período estudado: Barretos, Araçatuba e Presidente Prudente, que apresentaram uma média de população em seus municípios de 22.073, 17.016 e 16.208 habitantes, respectivamente.

As regionais do interior do estado apresentaram as maiores taxas de incidência (Figura 8).

Os casos distribuíram-se em 120 diferentes municípios, concentrando-se na região da grande São Paulo, com 260/463 casos $(56,2 \%)$. Somente a região do extremo oeste do estado foi poupada.

Dos 120 municípios que notificaram casos, 77 (64,2\%) municípios apresentaram casos possíveis de sarampo em apenas um ano e 19 (15,8\%) em dois anos de estudo. Somente três municípios tiveram casos em todos os anos: São Paulo, Campinas e São José do Rio Preto.

Os municípios com maior número de casos foram: São Paulo: 173 casos (37,4\%), Campinas: 30 casos (6,5\%), São José dos Campos: 12 casos (2,6\%) e Ribeirão Preto: 11 casos (2,4\%), os quais somaram 48,9\% de todos os pacientes do estudo.

Entretanto, os municípios com maior risco de apresentarem casos possíveis de sarampo foram os municípios com população menor que 14 mil habitantes (variando de 2.647 a 13.522 habitantes) que pertencem às regionais do interior do estado (Figura 9). Somente em um município ocorreu um surto de eritema infeccioso com três casos confirmados por laboratório (IAL-Central), em julho de 2004.

Tendo em vista a população do município de São Paulo, os casos foram analisados de acordo com o distrito administrativo de residência. No período de interesse o município contava com 96 distritos administrativos, com a menor população no distrito Marsilac (9.165 habitantes) e a maior população no DA Grajaú (385.578 habitantes) (SEADE, 2006). Dos 96 DA, 
$67(69,8 \%)$ apresentaram casos possíveis de sarampo e as maiores taxas de incidência foram apresentadas por diferentes distritos nos cinco anos de estudo, com exceção do DA da Vila Prudente que apresentou taxa de incidência de 4,0 e 3,0 por 100.000 habitantes em 2001 e 2002, respectivamente (Figura 10).

Figura 8. Taxa de incidência (por 100.000 habitantes) dos casos possíveis de sarampo $^{1}$ segundo Direção Regional de Saúde (DIR) de residência e ano dos primeiros sintomas. Estado de São Paulo, 2000-2004.
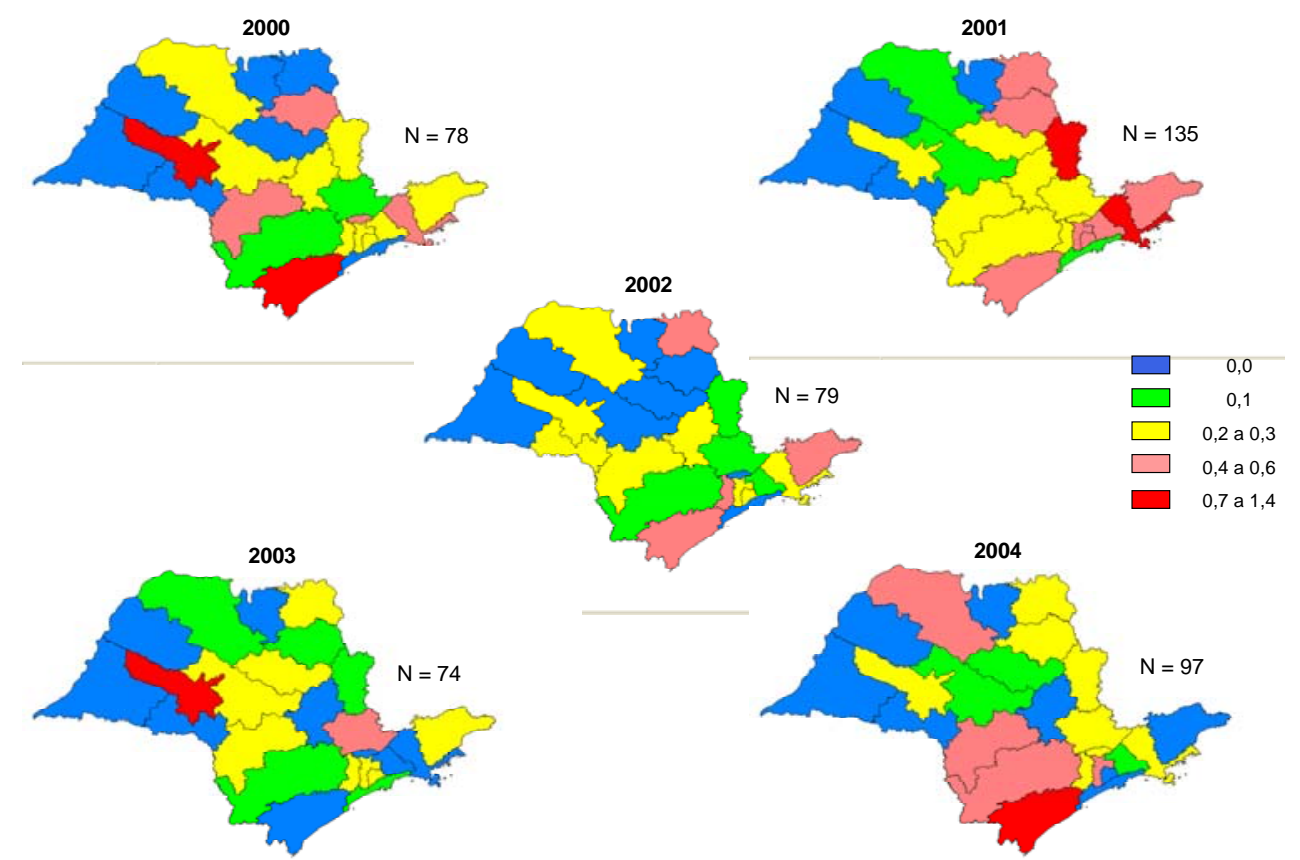

\footnotetext{
${ }^{1}$ Pacientes com anticorpos da classe IgM contra o sarampo identificados pelas técnicas de ELISA e/ou ELISA de captura
} 
Figura 9. Taxa de incidência (por 100.000 habitantes) dos casos possíveis de sarampo ${ }^{1}$ segundo município de residência e ano dos primeiros sintomas. Estado de São Paulo, 2000-2004.

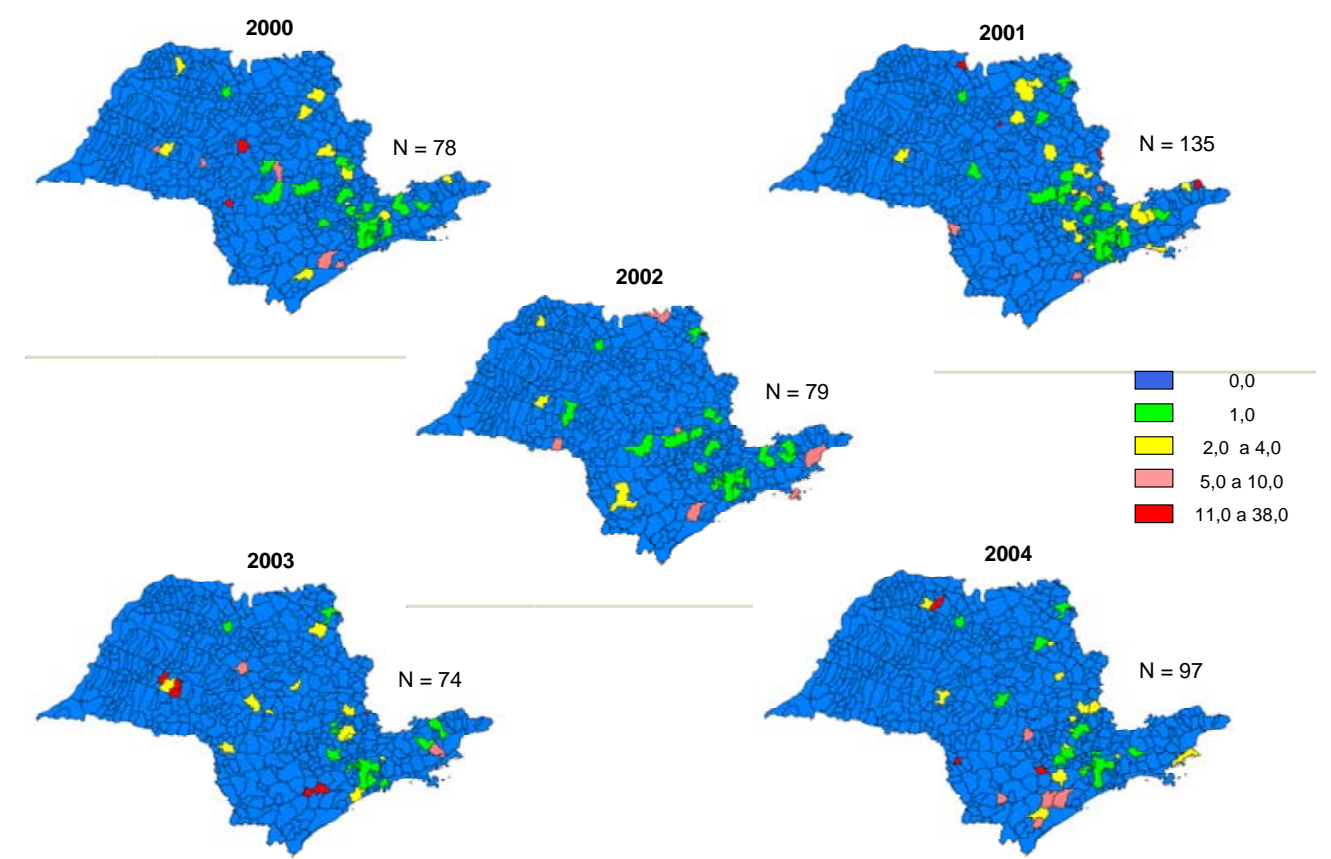

${ }^{1}$ Pacientes com anticorpos da classe IgM contra o sarampo identificados pelas técnicas de ELISA e/ou ELISA de captura

Figura 10. Taxa de incidência (por 100.000 habitantes) dos casos possíveis de sarampo ${ }^{1}$ segundo distrito administrativo (DA) de residência e ano dos primeiros sintomas. Município de São Paulo, 2000-2004.
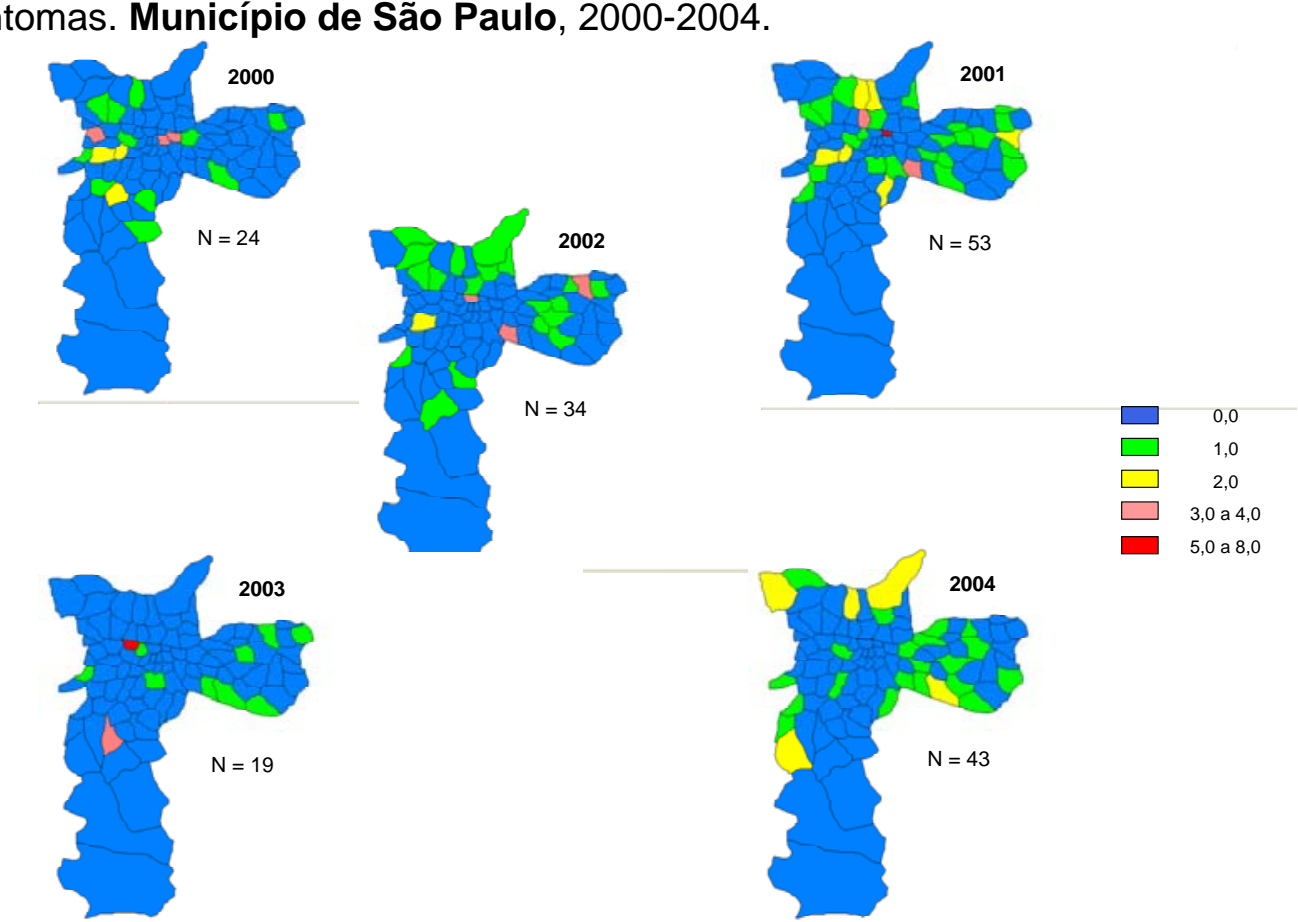

${ }^{1}$ Pacientes com anticorpos da classe IgM contra o sarampo identificados pelas técnicas de ELISA e/ou ELISA de captura 
Quanto à situação vacinal, a grande proporção dos casos, 391/463 $(84,4 \%)$, recebeu uma ou mais doses de vacina com o componente sarampo. Dos 391 casos sabidamente vacinados, $186(47,6 \%)$ e 153 $(39,1 \%)$ foram vacinados somente com a vacina do sarampo monovalente ou tríplice viral, respectivamente. Apenas 52/391 (13,3\%) casos foram vacinados com os dois imunobiológicos.

A idade média da aplicação dessas vacinas foi de 25,6 meses e mediana de 12 meses, variando de sete meses a 37 anos de idade. Entre os vacinados, 284/391 casos (72,6\%) encontravam-se vacinados nas idades preconizadas pelo programa de imunização (Tabela 8).

Entre os casos com apenas uma dose de vacina contra o sarampo e considerados não expostos à vacina, 18/49 (36,7\%) casos receberam a primeira e única dose dessa vacina com menos de dez meses de idade. Por sua vez, entre os que receberam duas doses de vacina contra o sarampo e não foram expostos à vacina, em $23 / 45(51,1 \%)$ casos a aplicação da primeira dose foi com menos de 10 meses de idade (Tabela 8).

Tabela 8. Casos possíveis de sarampo ${ }^{1}$ segundo número de doses, exposição à vacina do sarampo ${ }^{2,3}$ e faixa etária no momento da primo vacinação com o componente sarampo. Estado de São Paulo, 2000-2004.

\begin{tabular}{|c|c|c|c|c|c|c|}
\hline \multirow{2}{*}{$\begin{array}{l}\text { Idade à } \\
\text { época da } \\
\text { primo } \\
\text { vacinação } \\
\text { (em } \\
\text { meses) }\end{array}$} & \multicolumn{3}{|c|}{ Vacinado com 1 dose } & \multicolumn{3}{|c|}{ Vacinado com 2 doses } \\
\hline & $\begin{array}{c}\text { Não } \\
\text { exposto } \\
\end{array}$ & Exposto & Total & $\begin{array}{c}\text { Não } \\
\text { exposto }\end{array}$ & Exposto & Total \\
\hline 7 & $0(0,0)$ & $2(0,7)$ & $2(0,6)$ & $2(4,4)$ & $0(0,0)$ & $2(3,8)$ \\
\hline 8 & $1(2,0)$ & $1(0,3)$ & $2(0,6)$ & $1(2,3)$ & $0(0,0)$ & $1(1,9)$ \\
\hline 9 & $17(34,7)$ & $137(47,8)$ & $154(45,8)$ & $20(44,4)$ & $4(57,1)$ & $24(46,2)$ \\
\hline 10 & $2(4,1)$ & $13(4,5)$ & $15(4,4)$ & $1(2,3)$ & $3(42,9)$ & $4(7,7)$ \\
\hline 11 & $1(2,0)$ & $9(3,1)$ & $10(3,0)$ & $0(0,0)$ & $0(0,0)$ & $0(0,0)$ \\
\hline 12 & $7(14,3)$ & $97(33,8)$ & $104(31,0)$ & $2(4,4)$ & $0(0,0)$ & $2(3,8)$ \\
\hline$>=13$ & $21(42,9)$ & $28(9,8)$ & $49(14,6)$ & $19(42,2)$ & $0(0,0)$ & $19(36,6)$ \\
\hline Total & $49(100,0)$ & $287(100,0)$ & $336(100,0)$ & $45(100,0)$ & $7(100,0)$ & $52(100,0)$ \\
\hline
\end{tabular}


A distribuição dos casos segundo a exposição à vacina do sarampo e o mês dos primeiros sintomas (Figura 11) mostra, em praticamente todo o período, o predomínio dos casos expostos à vacina, com vários picos durante o período, frequentemente após as campanhas de seguimento. Os casos não expostos e não vacinados apresentam um aumento no final de 2001 e início de 2002 às custas da região da grande São Paulo. 
Figura 11. Casos possíveis de sarampo ${ }^{1}$ distribuídos mês a mês segundo a exposição à vacina do sarampo ${ }^{2,3}$ e a data dos primeiros sintomas. Estado de São Paulo, 2000-2004.

- Não exposto e Não vacinado $\rightarrow$ Não exposto e Vacinado $\longrightarrow$ Exposto Não exposto (total)

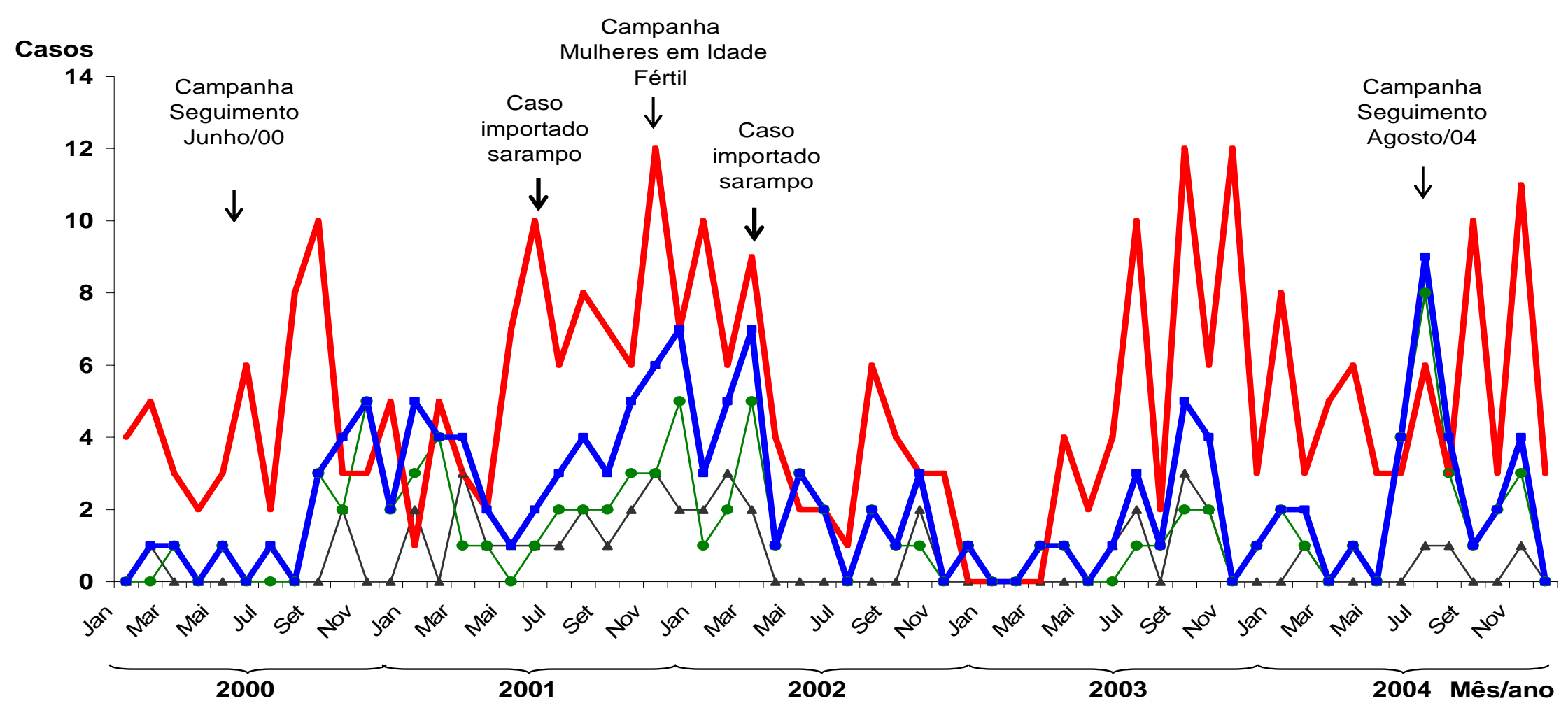

\footnotetext{
${ }^{1}$ Pacientes com anticorpos da classe IgM contra o sarampo identificados pelas técnicas de ELISA e/ou ELISA de captura

${ }^{2}$ Caso exposto à vacina: caso vacinado e coleta para diagnóstico de 8 a 56 dias da vacinação

${ }^{3}$ Foram excluídos 28 casos com situação vacinal ignorada
} 
Verifica-se que em 167/370 (45,1\%) casos o intervalo entre a data da aplicação da vacina com o componente sarampo e a data do início do exantema e/ou febre foi de cinco a 14 dias (Tabela 9). Esse grupo, parte dos 297 casos expostos à vacina e com presença de sinais e/ou sintomas característicos de evento adverso pós-vacina do sarampo, concentrou-se nas faixas de idade da primo vacinação. A distribuição dos casos, segundo os diferentes intervalos estudados, não mostrou diferenças no período de interesse.

Tabela 9. Casos possíveis de sarampo ${ }^{1}$ segundo a faixa etária e o intervalo (em dias) entre a vacina com o componente sarampo e os primeiros sintomas ${ }^{2}$. Estado de São Paulo, 2000-2004.

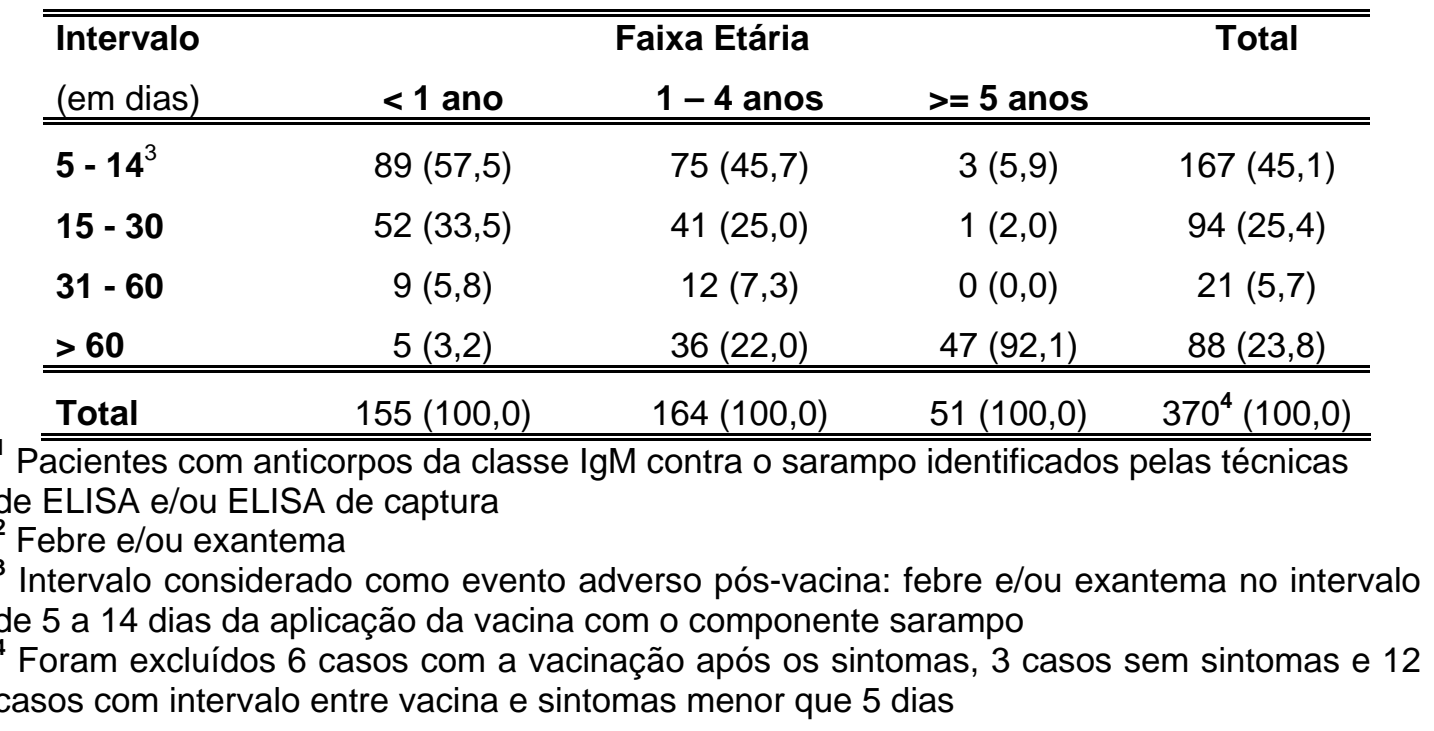

O maior percentual de vacinação ignorada foi observado nos maiores de 15 anos de idade, 21/ 28 (75,0\%) (Tabela 10).

Em 198/387 casos (51,2\%) o intervalo entre a aplicação da vacina com componente sarampo e a coleta da amostra de sangue concentrou-se no período de oito a 21 dias, seguido por $53(13,7 \%)$ casos com intervalo de 22 a 28 dias (Tabela 11). Essa distribuição não apresentou diferenças entre os anos de estudo. 
Tabela 10. Casos possíveis de sarampo ${ }^{1}$ segundo faixa etária e situação vacinal. Estado de São Paulo, 2000-2004.

\begin{tabular}{|c|c|c|c|c|}
\hline \multirow{3}{*}{$\begin{array}{l}\text { Faixa } \\
\text { Etária } \\
\text { (em meses/anos) }\end{array}$} & \multicolumn{3}{|c|}{ Situação Vacinal } & \multirow[t]{2}{*}{ Total } \\
\hline & Não & Sim & Ignorada & \\
\hline & $\mathrm{N} \quad(\%)$ & $\mathrm{N}(\%)$ & $\mathrm{N}(\%)$ & $\mathrm{N} \quad(\%)$ \\
\hline$=<6 \mathrm{~m}$ & $18(40,9)$ & $0(0,0)$ & $0(0,0)$ & $18(3,9)$ \\
\hline 7 - $8 m$ & $5(11,4)$ & $5(1,3)$ & $0(0,0)$ & $10(2,2)$ \\
\hline $9-11 m$ & $5(11,4)$ & $163(41,7)$ & $1(3,6)$ & $169(36,5)$ \\
\hline $12-23 m$ & $0(0,0)$ & $149(38,1)$ & $3(10,7)$ & $152(32,8)$ \\
\hline $2-4 a$ & $1(2,3)$ & $22(5,6)$ & $0(0,0)$ & $23(4,9)$ \\
\hline $5-9 a$ & $0(0,0)$ & $16(4,1)$ & $3(10,7)$ & $19(4,1)$ \\
\hline $10-14 a$ & $0(0,0)$ & $10(2,6)$ & $0(0,0)$ & $10(2,2)$ \\
\hline $15-19 a$ & $2(4,5)$ & $6(1,5)$ & $5(17,9)$ & $13(2,8)$ \\
\hline $20-29 a$ & $6(13,6)$ & $13(3,3)$ & $11(39,3)$ & $30(6,5)$ \\
\hline $30-39 a$ & $4(9,1)$ & $6(1,5)$ & $3(10,7)$ & $13(2,8)$ \\
\hline$>=40 \mathrm{a}$ & $3(6,8)$ & $1(0,3)$ & $2(7,1)$ & $6(1,3)$ \\
\hline Total & $44(100,0)$ & $391(100,0)$ & $28(100,0)$ & $463(100,0)$ \\
\hline
\end{tabular}

${ }^{1}$ Pacientes com anticorpos da classe IgM contra o sarampo identificados pelas técnicas de ELISA e/ou ELISA de captura

Tabela 11. Casos possíveis de sarampo ${ }^{1}$ segundo intervalo entre a aplicação da vacina com o componente sarampo e a coleta para o diagnóstico do sarampo. Estado de São Paulo, 2000-2004.

\begin{tabular}{|c|c|c|}
\hline Intervalo (em dias) & $\mathbf{N}$ & (\%) \\
\hline$=<7$ & 4 & $(1,0)$ \\
\hline $8-14$ & 90 & $(23,3)$ \\
\hline $15-21$ & 108 & $(27,9)$ \\
\hline $22-28$ & 53 & $(13,7)$ \\
\hline $29-35$ & 21 & $(5,4)$ \\
\hline $36-42$ & 9 & $(2,3)$ \\
\hline $43-49$ & 5 & $(1,3)$ \\
\hline $50-56$ & 7 & $(1,8)$ \\
\hline$>56$ & 90 & $(23,3)$ \\
\hline Total & $387^{2}$ & $(100,0)$ \\
\hline
\end{tabular}


Quanto aos aspectos laboratoriais, foram observados 56 e 14 resultados, respectivamente, indeterminados e não reagentes pelo teste Behring, e quando testados com o ELISA de captura (CDC) mostraram-se reagentes. Houve um maior percentual de positividade com o ELISA Behring. Neste estudo, sem a utilização do segundo teste (CDC), 71 (15,3\%) casos não teriam sido identificados (Tabela 12).

Tabela 12. Casos possíveis de sarampo $^{1}$ segundo resultado do exame imunodiagnóstico (Elisa: teste Behring e Elisa de captura: CDC). Estado de São Paulo, 2000-2004.

\begin{tabular}{lcccc}
\hline \hline Resultado & \multicolumn{2}{c}{ IgM sarampo (Behring) } & \multicolumn{2}{c}{ IgM captura sarampo (CDC) } \\
& $\mathbf{N}$ & $\mathbf{( \% )}$ & $\mathbf{N}$ & $\mathbf{( \% )}$ \\
\hline \hline Reagente & 392 & $(84,7)$ & 289 & $(62,4)$ \\
Não reagente & 14 & $(3,0)$ & 161 & $(34,8)$ \\
Indeterminado & 56 & $(12,1)$ & 0 & $(0,0)$ \\
Não realizado & 1 & $(0,2)$ & 13 & $(2,8)$ \\
\hline \hline Total & $\mathbf{4 6 3}$ & $\mathbf{( 1 0 0 , 0 )}$ & $\mathbf{4 6 3}$ & $\mathbf{( 1 0 0 , 0 )}$ \\
\hline \hline & \multicolumn{4}{l}{} \\
Pacientes com anticorpos da classe IgM contra o sarampo identificados pelas técnicas \\
de ELISA e/ou ELISA de captura \\
Casos analisados somente por uma das técnicas
\end{tabular}

A exposição à vacina do sarampo e o teste realizado mostraram que entre os casos não vacinados há uma maior proporção de positividade, 36/44 (81,8\%), da imunoglobulina IgM quando utilizado o teste ELISA (Behring), se comparado com o ELISA de captura (CDC), 19/44 (43,2\%) (Tabela 13).

O intervalo menor de quatro dias entre o exantema e a primeira coleta apresentou a maior proporção de positividade para anticorpos da classe IgM (ELISA e ELISA de captura) (Tabela 14). 
Tabela 13. Casos possíveis de sarampo ${ }^{1}$ segundo exposição à vacina do sarampo ${ }^{2}$ e resultados de ELISA Behring e ELISA de captura (CDC) para IgM específico de sarampo. Estado de São Paulo, 2000-2004.

\begin{tabular}{|c|c|c|c|c|}
\hline \multirow{3}{*}{$\begin{array}{l}\text { Teste (sarampo) } \\
\text { Resultado }\end{array}$} & \multicolumn{2}{|c|}{ Não exposto } & \multirow{2}{*}{$\begin{array}{l}\text { Exposto } \\
\mathrm{N}=297\end{array}$} & \multirow{2}{*}{$\begin{array}{c}\text { Total } \\
\mathrm{N}=435^{3}\end{array}$} \\
\hline & $\begin{array}{c}\text { Não vacinado } \\
\qquad N=44\end{array}$ & $\begin{array}{c}\text { Vacinado } \\
\mathrm{N}=94\end{array}$ & & \\
\hline & $\mathrm{N} \quad(\%)$ & $\mathrm{N} \quad(\%)$ & $\mathrm{N} \quad(\%)$ & $\mathrm{N} \quad(\%)$ \\
\hline \multicolumn{5}{|l|}{ IgM (Behring) } \\
\hline Reagente & $36(81,8)$ & $74(78,7)$ & $257(86,5)$ & $367(84,4)$ \\
\hline Não reagente & $1(2,3)$ & $6(6,4)$ & $7(2,4)$ & $14(3,2)$ \\
\hline Indeterminado & $7(15,9)$ & $14(14,9)$ & $32(10,8)$ & $53(12,2)$ \\
\hline Não realizado & $0(0,0)$ & $0(0,0)$ & $1(0,3)$ & $1(0,2)$ \\
\hline \multicolumn{5}{|l|}{$\operatorname{lgM}(C D C)$} \\
\hline Reagente & $19(43,2)$ & $32(34,0)$ & $228(76,8)$ & $279(64,1)$ \\
\hline Não reagente & $25(56,8)$ & $59(62,8)$ & $59(19,9)$ & $143(32,9)$ \\
\hline Indeterminado & $0(0,0)$ & $0(0,0)$ & $0(0,0)$ & $0(0,0)$ \\
\hline Não realizado & $0(0,0)$ & $3(3,2)$ & $10(3,3)$ & $13(3,0)$ \\
\hline
\end{tabular}

Tabela 14. Casos possíveis de sarampo $^{1}$ com resultado reagente para a imunoglobulina M (IgM) segundo intervalo entre o início do exantema e a coleta da amostra de sangue. Estado de São Paulo, 2000-2004.

\begin{tabular}{lcc}
\hline \hline $\begin{array}{l}\text { Testel } \\
\text { Intervalo (em dias) }\end{array}$ & $\mathbf{N}$ & $\mathbf{( \% )}$ \\
\hline \hline IgM reagente (Behring) & & \\
$=<3$ & 230 & $(60,5)$ \\
$4-11$ & 132 & $(34,7)$ \\
$12-28$ & 17 & $(4,5)$ \\
$>28$ & 1 & $(0,3)$ \\
Total & $\mathbf{3 8 0 ^ { 2 }}$ & $(\mathbf{1 0 0 , 0 )}$ \\
IgM reagente (CDC) & & \\
$=<3$ & 175 & $(61,4)$ \\
$4-11$ & 99 & $(34,7)$ \\
$12-28$ & 11 & $(3,9)$ \\
$>28$ & 0 & $(0,0)$ \\
Total & $\mathbf{2 8 5}$ & $(\mathbf{1 0 0 , 0 )}$ \\
\hline Pacientes com anticorpos da classe IgM contra o sarampo identificados pelas \\
técnicas de ELISA e/ou ELISA de captura \\
2 Foram excluídos 12 casos sem exantema \\
${ }^{3}$ Foram excluídos 4 casos sem exantema
\end{tabular}


Nos cinco anos de estudo, em alguns casos selecionados pelo CVE com apresentação de clínica não característica para sarampo foram processados, pelo IAL-Central, exames para o diagnóstico de exantema súbito, eritema infeccioso, dengue, entre outras doenças febris exantemáticas.

Neste estudo, foram encontrados $303 / 463$ (65,4\%) casos com simultaneidade de anticorpos contra sarampo e contra outras doenças exantemáticas. As mais representadas foram: rubéola: 105/463 (22,7\%), herpes vírus 6: $113 / 463(24,4 \%)$ e o parvovírus B19: 79/463 (17,1\%).

Nas tabelas 15 a 17 referentes aos casos de rubéola, herpes vírus 6 e parvovírus B19 foram excluídos os casos com vacinação ignorada.

Dos 463 casos, 105 (22,7\%) apresentaram anticorpos da classe IgM contra a rubéola. A faixa etária mais atingida foi a de um ano de idade $(82,6 \%)$, na qual é recomendada a primeira dose da vacina tríplice viral (sarampo, caxumba e rubéola). A maioria dos casos (81/92) foi exposto à vacina recentemente $(88,0 \%)$ (Tabela 15$)$. Desses casos, 33/81 $(40,7 \%)$ casos foram considerados evento adverso pós-vacina. Observou-se um aumento de casos de julho a novembro $(61,0 \%)$, com exceção do mês de agosto.

Do total dos 463 casos, $113(24,4 \%)$ e $79(17,1 \%)$ casos apresentaram também anticorpos da classe IgM contra o herpes vírus 6 e contra o parvovírus B19, respectivamente.

Dos 105 casos com anticorpos da classe IgM contra o herpes vírus 6 segundo exposição à vacina, 91/105 (86,7\%) casos concentraram-se nos menores de dois anos de idade e 74/105 (70,5\%) atingiram indivíduos expostos à vacina recentemente (Tabela 16). A média e a mediana de duração do exantema foram de 3,8 e 3 dias, respectivamente. Esses casos apresentaram média de duração da febre de 3,3 dias, com mediana de 3 dias. A febre teve início antes do exantema em 70/105 (66,7\%) casos. A maior concentração de casos $(54,7 \%)$ ocorreu nos meses de julho a novembro. 
Quanto aos casos com anticorpos da classe IgM contra o parvovírus B 19, as faixas etárias mais atingidas foram: nove a 11 meses (24,3\%), um ano de idade $(23,0 \%)$ e 20 a 29 anos (13,5\%) (Tabela 17). A média e mediana de duração do exantema foram de 3,5 e 3 dias, respectivamente, e a média de duração da febre de 2,6 dias, com mediana de 2 dias. Observouse um aumento de casos $(55,8 \%)$ entre os meses de julho e novembro, com exceção de agosto.

Além desses agravos, foram encontrados também 6/463 (1,3\%) casos com anticorpos da classe lgM contra a dengue.

Observou-se também a simultaneidade de anticorpos da classe IgM contra mais de dois vírus. Os agravos mais representados foram: 25/463 $(5,4 \%)$ casos com IgM contra sarampo, rubéola e herpes vírus 6; 15/463 $(3,2 \%)$ casos com IgM contra sarampo, herpes vírus 6 e parvovírus B19 e 13/463 (2,8\%) casos com IgM contra sarampo, rubéola e parvovírus B19. 
Tabela 15. Casos possíveis de sarampo ${ }^{1}$ com anticorpos da classe IgM contra a rubéola ${ }^{2}$ segundo exposição à vacina com o componente sarampo ${ }^{3,4}$. Estado de São Paulo, 2000-2004.

\begin{tabular}{|c|c|c|c|c|}
\hline \multirow[t]{3}{*}{ Característica } & \multicolumn{2}{|c|}{ Não exposto } & \multirow{3}{*}{$\begin{array}{l}\text { Exposto } \\
\begin{array}{l}\mathrm{N}=81 \\
\mathrm{~N}(\%)\end{array} \\
\end{array}$} & \multirow{3}{*}{$\begin{array}{l}\text { Total } \\
\mathrm{N}=92^{4} \\
\mathrm{~N} \quad(\%)\end{array}$} \\
\hline & $\begin{array}{c}\text { Não vacinado } \\
N=6\end{array}$ & $\begin{array}{c}\text { Vacinado } \\
\mathrm{N}=5\end{array}$ & & \\
\hline & & & & \\
\hline \multicolumn{5}{|l|}{ Sexo } \\
\hline Fem & $4(66,7)$ & $1(20,0)$ & $44(54,3)$ & $49(53,3)$ \\
\hline Masc & $2(33,3)$ & $4(80,0)$ & $37(45,7)$ & $43(46,7)$ \\
\hline \multicolumn{5}{|c|}{ Faixa Etária (meses/anos) } \\
\hline$<9 \mathrm{~m}$ & $0(0,0)$ & $0(0,0)$ & $0(0,0)$ & $0(0,0)$ \\
\hline $9-11 m$ & $0(0,0)$ & $1(20,0)$ & $4(4,9)$ & $5(5,4)$ \\
\hline $12-23 m$ & $0(0,0)$ & $1(20,0)$ & $75(92,6)$ & $76(82,6)$ \\
\hline $2-4 a$ & $0(0,0)$ & $0(0,0)$ & $2(2,5)$ & $2(2,2)$ \\
\hline $5-9 a$ & $0(0,0)$ & $0(0,0)$ & $0(0,0)$ & $0(0,0)$ \\
\hline $10-14 a$ & $0(0,0)$ & $0(0,0)$ & $0(0,0)$ & $0(0,0)$ \\
\hline $15-19 a$ & $2(33,3)$ & $0(0,0)$ & $0(0,0)$ & $2(2,2)$ \\
\hline $20-29 a$ & $2(33,3)$ & $3(60,0)$ & $0(0,0)$ & $5(5,4)$ \\
\hline$>=30 \mathrm{a}$ & $2(33,4)$ & $0(0,0)$ & $0(0,0)$ & $2(2,2)$ \\
\hline \multicolumn{5}{|l|}{ Caso suspeito $^{5}$} \\
\hline Não & $3(50,0)$ & $2(40,0)$ & $35(43,2)$ & $40(43,5)$ \\
\hline Sim & $3(50,0)$ & $3(60,0)$ & $45(55,6)$ & $51(55,4)$ \\
\hline Ignorado & $0(0,0)$ & $0(0,0)$ & $1(1,2)$ & $1(1,1)$ \\
\hline \multicolumn{5}{|c|}{ Clínica específica $^{6}$} \\
\hline Não & $5(83,3)$ & $4(80,0)$ & $67(82,7)$ & $76(82,6)$ \\
\hline Sim & $1(16,7)$ & $1(20,0)$ & $12(14,8)$ & $14(15,2)$ \\
\hline Ignorado & $0(0,0)$ & $0(0,0)$ & $2(2,5)$ & $2(2,2)$ \\
\hline
\end{tabular}

${ }^{1}$ Pacientes com anticorpos da classe IgM contra o sarampo identificados pelas técnicas de ELISA e/ou ELISA de captura

${ }^{2}$ ELISA de captura

${ }^{3}$ Caso exposto à vacina: caso vacinado e coleta para diagnóstico de 8 a 56 dias da vacinação

${ }^{4}$ Foram excluídos 13 casos com vacinação ignorada

${ }^{5}$ Caso suspeito de sarampo: febre, exantema e tosse e/ou coriza e/ou conjuntivite

${ }^{6}$ Clínica específica de sarampo: caso suspeito e febre maior que 2 dias e anterior ao exantema e, este com duração maior que 2 dias 
Tabela 16. Casos possíveis de sarampo ${ }^{1}$ com anticorpos da classe IgM contra o herpes vírus $6^{2}$ (exantema súbito) segundo exposição à vacina com o componente sarampo ${ }^{3,4}$. Estado de São Paulo, 2000-2004.

\begin{tabular}{|c|c|c|c|c|}
\hline \multirow[t]{3}{*}{ Característica } & \multicolumn{2}{|c|}{ Não exposto } & \multirow{3}{*}{$\begin{array}{l}\text { Exposto } \\
\qquad \begin{array}{l}N=74 \\
N(\%)\end{array}\end{array}$} & \multirow{3}{*}{$\begin{array}{l}\text { Total } \\
\begin{aligned} \mathrm{N}=105^{4} \\
\mathrm{~N}(\%)\end{aligned}\end{array}$} \\
\hline & $\begin{array}{l}\text { Não vacinado } \\
\qquad N=10\end{array}$ & $\begin{array}{c}\text { Vacinado } \\
N=21\end{array}$ & & \\
\hline & $\mathrm{N}(\%)$ & $\mathrm{N}(\%)$ & & \\
\hline \multicolumn{5}{|l|}{ Sexo } \\
\hline Fem & $3(30,0)$ & $11(52,4)$ & $31(41,9)$ & $45(42,9)$ \\
\hline Masc & $7(70,0)$ & $10(47,6)$ & $43(58,1)$ & $60(57,1)$ \\
\hline \multicolumn{5}{|c|}{ Faixa Etária (meses/anos) } \\
\hline$<9 \mathrm{~m}$ & $8(80,0)$ & $0(0,0)$ & $2(2,7)$ & $10(9,5)$ \\
\hline $9-11 m$ & $1(10,0)$ & $3(14,3)$ & $36(48,6)$ & $40(38,1)$ \\
\hline $12-23 m$ & $0(0,0)$ & $6(28,6)$ & $35(47,3)$ & $41(39,1)$ \\
\hline $2-4 a$ & $0(0,0)$ & $5(23,8)$ & $1(1,4)$ & $6(5,7)$ \\
\hline $5-9 a$ & $0(0,0)$ & $2(9,5)$ & $0(0,0)$ & $2(1,9)$ \\
\hline $10-14 a$ & $0(0,0)$ & $2(9,5)$ & $0(0,0)$ & $2(1,9)$ \\
\hline $15-19 a$ & $0(0,0)$ & $2(9,5)$ & $0(0,0)$ & $2(1,9)$ \\
\hline $20-29 a$ & $1(10,0)$ & $1(4,8)$ & $0(0,0)$ & $2(1,9)$ \\
\hline$>=30 \mathrm{a}$ & $0(0,0)$ & $0(0,0)$ & $0(0,0)$ & $0(0,0)$ \\
\hline \multicolumn{5}{|l|}{ Caso suspeito $^{5}$} \\
\hline Não & $1(10,0)$ & $5(23,8)$ & $19(25,7)$ & $24(22,9)$ \\
\hline Sim & $9(90,0)$ & $15(71,4)$ & $54(73,0)$ & $79(75,2)$ \\
\hline Ignorado & $0(0,0)$ & $1(4,8)$ & $1(1,3)$ & $2(1,9)$ \\
\hline \multicolumn{5}{|c|}{ Clínica específica $^{6}$} \\
\hline Não & $5(50,0)$ & $15(71,4)$ & $58(78,4)$ & $78(74,3)$ \\
\hline Sim & $5(50,0)$ & $5(23,8)$ & $13(17,6)$ & $23(21,9)$ \\
\hline Ignorado & $0(0,0)$ & $1(4,8)$ & $3(4,0)$ & $4(3,8)$ \\
\hline \multicolumn{5}{|c|}{$\begin{array}{l}{ }^{1} \text { Pacientes com anticorpos da classe IgM contra o sarampo identificados pelas técnicas d } \\
\text { ELISA e/ou ELISA de captura } \\
{ }^{2} \text { Imunofluorescência indireta e/ou PCR }\end{array}$} \\
\hline \multicolumn{5}{|c|}{$\begin{array}{l}{ }^{3} \text { Caso exposto à vacina: caso vacinado e coleta para diagnóstico de } 8 \text { a } 56 \text { dias } \\
\text { da vacinação } \\
{ }^{4} \text { Foram excluídos } 8 \text { casos com vacinação ignorada }\end{array}$} \\
\hline \multicolumn{5}{|c|}{${ }^{5}$ Caso suspeito de sarampo: febre, exantema e tosse e/ou coriza e/ou conjuntivite } \\
\hline
\end{tabular}


Tabela 17. Casos possíveis de sarampo ${ }^{1}$ com anticorpos da classe IgM contra o Parvovírus ${\mathrm{B} 19^{2}}^{2}$ (eritema infeccioso) segundo exposição à vacina com 0 componente sarampo ${ }^{3,4}$. Estado de São Paulo, 2000-2004.

\begin{tabular}{|c|c|c|c|c|}
\hline \multirow[t]{3}{*}{ Característica } & \multicolumn{2}{|c|}{ Não exposto } & \multirow{2}{*}{$\begin{array}{l}\text { Exposto } \\
\qquad N=32\end{array}$} & \multirow{2}{*}{$\begin{array}{c}\text { Total } \\
\mathrm{N}=74^{4}\end{array}$} \\
\hline & $\begin{array}{c}\text { Não vacinado } \\
\qquad N=5\end{array}$ & $\begin{array}{c}\text { Vacinado } \\
\mathbf{N}=\mathbf{3 7}\end{array}$ & & \\
\hline & $\mathrm{N}(\%)$ & N (\%) & $\mathrm{N} \quad(\%)$ & $\mathrm{N}(\%)$ \\
\hline \multicolumn{5}{|l|}{ Sexo } \\
\hline Fem & $3(60,0)$ & $22(59,5)$ & $22(68,7)$ & $47(63,5)$ \\
\hline Masc & $2(40,0)$ & $15(40,5)$ & $10(31,3)$ & $27(36,5)$ \\
\hline \multicolumn{5}{|c|}{ Faixa Etária (meses/anos) } \\
\hline$<9 m$ & $3(60,0)$ & $0(0,0)$ & $0(0,0)$ & $3(4,1)$ \\
\hline $9-11 m$ & $0(0,0)$ & $2(5,4)$ & $16(50,0)$ & $18(24,3)$ \\
\hline $12-23 m$ & $0(0,0)$ & $4(10,8)$ & $13(40,6)$ & $17(23,0)$ \\
\hline $2-4 a$ & $0(0,0)$ & $7(18,9)$ & $1(3,1)$ & $8(10,8)$ \\
\hline $5-9 a$ & $0(0,0)$ & $9(24,4)$ & $0(0,0)$ & $9(12,2)$ \\
\hline $10-14 a$ & $0(0,0)$ & $4(10,8)$ & $0(0,0)$ & $4(5,4)$ \\
\hline $15-19 a$ & $0(0,0)$ & $2(5,4)$ & $0(0,0)$ & $2(2,7)$ \\
\hline $20-29 a$ & $2(40,0)$ & $6(16,2)$ & $2(6,3)$ & $10(13,5)$ \\
\hline$>=30 \mathrm{a}$ & $0(0,0)$ & $3(8,1)$ & $0(0,0)$ & $3(4,1)$ \\
\hline \multicolumn{5}{|l|}{ Caso suspeito ${ }^{5}$} \\
\hline Não & $3(60,0)$ & $21(56,8)$ & $12(37,5)$ & $36(48,6)$ \\
\hline Sim & $2(40,0)$ & $16(43,2)$ & $20(62,5)$ & $38(51,4)$ \\
\hline \multicolumn{5}{|c|}{ Clínica específica ${ }^{6}$} \\
\hline Não & $4(80,0)$ & $34(91,9)$ & $27(84,4)$ & $65(87,8)$ \\
\hline Sim & $1(20,0)$ & $3(8,1)$ & $4(12,5)$ & $8(10,8)$ \\
\hline Ignorado & $0(0,0)$ & $0(0,0)$ & $1(3,1)$ & $1(1,4)$ \\
\hline
\end{tabular}

${ }^{1}$ Pacientes com anticorpos da classe IgM contra o sarampo identificados pelas técnicas de ELISA e/ou ELISA de captura

${ }^{2}$ ELISA de captura

${ }^{3}$ Caso exposto à vacina: caso vacinado e coleta para diagnóstico de 8 a 56 dias da vacinação

${ }^{4}$ Foram excluídos 5 casos com vacinação ignorada

${ }^{5}$ Caso suspeito de sarampo: febre, exantema e tosse e/ou coriza e/ou conjuntivite

${ }^{6}$ Clínica específica de sarampo: caso suspeito e febre maior que 2 dias e anterior ao exantema e, este com duração maior que 2 dias 


\section{DISCUSSÃo}

ALFRED EVANS (1985) em artigo clássico sobre erradicação de doenças infecciosas afirmou existirem três níveis biológicos de controle: a) o controle da doença clínica e de suas seqüelas, assim como da mortalidade a ela associada; b) o controle da infecção, com manifestação clínica ou assintomática; c) o controle da presença do agente causal no ambiente e nas fontes de infecção. Este autor salienta também que, todos esses níveis devem ser atingidos antes que a erradicação seja possível.

Durante o período deste estudo foram confirmados casos autóctones de sarampo no Brasil somente no ano 2000 (PREVOTS et al., 2003; MS, 2005), portanto, tudo indica que a primeira etapa assinalada por EVANS (1985) foi atingida, sendo necessário neste momento que a vigilância focalize seus esforços na tentativa de identificar resíduos de suscetíveis e de fontes de infecção, sejam elas autóctones ou importadas.

Os resultados encontrados apontam para o bom desempenho da vigilância da síndrome febril exantemática, que apresentou elevada sensibilidade entre 2000 e 2004, identificando aproximadamente 46.000 casos suspeitos, dos quais, cerca de 1,0\% apresentou anticorpos da classe IgM contra o sarampo e esses casos foram selecionados para esta pesquisa. No período de estudo, foram registradas elevadas taxas de notificação de doenças exantemáticas, (23 casos por 100.000 habitantes), quando comparada aos demais países da região das Américas e da OMS (HARPAZ e PAPANIA, 2004).

A vigilância também se mostrou oportuna, seja em relação à investigação dos casos possíveis de sarampo, com 90\% deles investigados em até oito dias após o início do exantema (mediana de dois dias), seja com referência a investigação etiológica, com $97 \%$ das coletas de amostras efetuadas até 28 dias após o aparecimento do exantema, portanto em período adequado, abaixo dos 30 dias preconizados pela OPAS (DIETZ et al., 2004; MS, 2003, 2005). 
Além disso, para minimizar a falta de integralidade de dados, condição muito freqüente na vigilância passiva (BARROS e SILVA, 2006), foi realizada investigação complementar, por meio de visitas domiciliárias e/ou de contatos telefônicos. Com esta estratégia foi possível diminuir o percentual de ausência de informações relativas às variáveis de interesse, permitindo, por exemplo, elevada proporção $(84,4 \%)$ de casos com informação documentada da aplicação da vacina contra o sarampo.

O componente chave do programa de eliminação do sarampo é a rede de laboratório criada na região das Américas em 1995 (DIETZ et al., 2004). Em todo o período de interesse, essa rede utilizou o mesmo kit comercial de ELISA (Behring) que apresenta alta sensibilidade e especificidade (ERDMAN et al., 1991; RATNAM et al., 2000; DIETZ et al., 2004).

No estado de São Paulo, nesse mesmo período, as amostras reagentes para a imunoglobulina da classe $\mathrm{M}$ com o kit comercial Behring, foram submetidas a outro teste, o ELISA de captura do CDC, na rotina da vigilância do sarampo.

A presença de anticorpos da classe $\operatorname{lgM}$ foi confirmada mediante resultado reagente em ao menos um desses testes. Esta conduta foi preconizada considerando a necessidade de elevada sensibilidade da vigilância em função do Plano de Eliminação do Sarampo.

\section{Limitações do estudo}

A despeito do bom desempenho nos indicadores de qualidade da vigilância, sabe-se que dados obtidos a partir de sistemas de vigilância, especialmente, de sistemas passivos, devem ser interpretados com cautela, pelas características que lhes são próprias, destacando-se a subnotificação, a baixa representatividade, a dificuldade da perfeita compreensão e padronização das diferentes definições de caso utilizadas, particularmente em se tratando de vigilância por síndrome (BARROS e SILVA, 2006; WALDMAN, 2006).

O pequeno número de casos (25/463) que referiu contato com casos 
semelhantes a sarampo e/ou rubéola deve estar subestimando esse tipo de exposição, considerando que o sarampo tem transmissão anterior ao início do exantema.

A definição adotada de exposição à vacina do sarampo, fundamentada em estudo de HELFAND et al. (1999) que observou $10 \%$ das crianças com presença de anticorpos da classe IgM específicos até oito semanas após a vacinação contra o sarampo, pode estar superestimando este grupo.

Outro aspecto a ser considerado na interpretação dos resultados apresentados diz respeito à diminuição do valor preditivo positivo, dos instrumentos utilizados na confirmação de casos, em cenários de grande redução ou ausência da circulação do vírus (TUOKKO, 1984; PAHO, 2001a, 2001b; VENCZEL et al., 2003; DIETZ et al., 2004).

Uma forte limitação na interpretação das informações laboratoriais no grupo estudado foi a não realização do teste de avidez para anticorpos da classe IgG contra o sarampo. Tal método permite a diferenciação entre resposta primária e secundária. Na infecção primária, a resposta humoral inicial produz anticorpos da classe lgG de baixa avidez, que são substituídos gradativamente por anticorpos de maior avidez caracterizando infecção antiga (SOUZA et al., 1997). O teste de avidez é um método útil na avaliação da eficácia/efetividade de vacinas, assim como na identificação de falhas vacinais (SOUZA et al., 1997; PANNUTI et al., 2004; HAMKAR et al., 2006). Essa limitação não permitiu discriminar se os casos estudados apresentavam uma infecção primária ou uma resposta à infecção passada, ou ainda, distinguir entre a falha vacinal primária e secundária (PANNUTI et al., 2004; HAMKAR et al., 2006).

Outro obstáculo para análise, foi a simultaneidade da presença de anticorpos da classe IgM contra mais de um vírus produtor de exantema. Resultados semelhantes foram encontrados recentemente por vários autores (TUOKKO, 1984; DONOVAN, 1997; THOMAS et al., 1999; NAVALPOTRO et al., 2006). A interpretação de tal achado é controversa, pois vários estudos têm sugerido que a utilização de um teste ELISA de captura, para a 
detecção de anticorpos da classe IgM, reduz a probabilidade de resultados falsos positivos devido ao fator reumatóide (ERDMAN et al., 1991; HUMMEL et al., 1992; HELFAND et al., 1997).

Desta forma, para a investigação epidemiológica desses casos é imprescindível saber se é uma infecção recente ou uma resposta secundária. Mais uma vez, reforça a importância e a necessidade da prova de avidez. Na ausência desse teste, é necessário aceitar a possibilidade de resultado falso positivo para presença de anticorpos da classe IgM em um dos dois testes reagentes.

\section{Aspectos Epidemiológicos}

Com a finalidade de facilitar a identificação de possíveis resíduos de fontes de infecção, a população de estudo foi dividida em dois grupos, um deles formado por casos expostos à vacina e outro por casos não expostos à vacina (HELFAND et al., 1999), esse último foi subdividido em vacinados e não vacinados.

$\mathrm{Na}$ caracterização dos casos estudados, chama a atenção o predomínio do sexo feminino nos três grupos (Tabela 3). Os casos entre os menores de nove meses ou nos maiores de nove anos, faixas etárias nas quais, mais provavelmente, podem-se encontrar resíduos de fontes de infecção do sarampo (Tabela 7), verifica-se o predomínio de mulheres em idade fértil. Considerando que a infecção depende da taxa de contato com pessoas infectadas (MOSS e OTA, 2007), é plausível a hipótese de que o convívio com crianças tenha sido importante na cadeia de transmissão entre os indivíduos com síndrome febril exantemática.

$\mathrm{Na}$ distribuição dos casos segundo a idade, o grupo dos menores de nove meses concentra elevada proporção dos não vacinados (Tabela 3). Nesse grupo etário a infecção pelo vírus do sarampo depende da taxa de declínio dos anticorpos maternos (MOSS e OTA, 2007).

Sabe-se que em populações altamente vacinadas, na qual por longo período houve pequena circulação do vírus do sarampo, a imunidade passiva entre recém-nascidos, é baixa e de pequena duração, 
desaparecendo nos primeiros meses após o nascimento (KACICA et al., 1995; SZENBORN et al., 2003). O fato da epidemia de 1997, no município de São Paulo, apresentar incidência mais elevada no grupo dos menores de um ano de idade é consistente com o desaparecimento precoce dos anticorpos maternos (CAMARGO et al., 2000).

A distribuição dos casos possíveis de sarampo segundo a idade e a distribuição no tempo, (Figura 5), mostra claro predomínio do grupo etário de nove a 11 meses, em praticamente todo o período de 2000 a 2002, e do grupo de 12 a 15 meses nos anos seguintes. Essa mudança coincide com a alteração do calendário de vacinação de nove para os 12 meses, com o predomínio dos casos expostos recentemente à vacina durante todo o período de interesse. No período de 2000 a 2002 (Figura 5), o segundo grupo etário mais representado foi o de maiores de 60 meses, que em dois meses de 2001, superou o grupo de nove a 11 meses.

Cabe assinalar que o ano 2001 concentrou cerca de $30 \%$ dos casos possíveis de sarampo, com dois casos importados identificados, respectivamente, em junho de 2001 e em março de 2002.

Em relação ao grupo etário dos maiores de 60 meses (Figura 5) não é possível formular uma hipótese tão forte como aquela relativa aos grupos etários de nove a 11 meses e de 12 a 15 meses, mas pode-se afastar, com alguma segurança, uma associação com o exantema súbito (HALL et al, 1994; YAMANISHI, 2001; SES, 2002; MS, 2003; STRAUS, 2005; MARQUES e SAKANE, 2006). No entanto, não é possível excluir a possibilidade de que parte desses casos envolva a infecção pelo vírus da rubéola, especialmente, entre os maiores de 15 anos (Tabela 15). Mesmo assim, a ocorrência de infecção pelo vírus do sarampo é plausível, em face da elevada infectividade do vírus, de elevada proporção de casos possíveis, entre junho de 2001 e início de 2002, coincidindo com a identificação de dois casos importados de sarampo.

A distribuição dos casos no tempo, segundo a exposição à vacina (Figura 11), mostra dois picos de não expostos recentemente à vacina precedendo a identificação do primeiro caso importado e outros dois picos 
entre as datas do diagnóstico dos dois casos de sarampo importados. Tais dados fortalecem a plausibilidade da ocorrência de infecção pelo vírus do sarampo, ainda que esses casos estejam dispersos no espaço e que parcela ponderável dos não expostos recentemente à vacina seja composta de indivíduos vacinados (Tabela 3).

A distribuição dos casos não expostos recentemente à vacina com uma ou duas doses, segundo a idade de aplicação da primeira dose (Tabela 8), sugere a possibilidade de falhas primárias e secundárias, em virtude da elevada proporção de casos possíveis de sarampo sem exposição recente à vacina, entre os que receberam a primeira dose com idade inferior a dez meses (LINNEMANN et al., 1982; POLAND et al., 1997).

A freqüência da falha vacinal primária é variável, depende da idade da vacinação, do número de doses e de problemas operacionais das atividades de vacinação (PANNUTI et al., 2004). A importância da presença de suscetíveis ao sarampo em função da falha primária é controversa. Uma das questões importantes para a compreensão da epidemiologia do sarampo em populações altamente vacinadas e sem transmissão endêmica, é a possibilidade da transmissão, dessa doença, ser sustentada exclusivamente entre os casos com falha vacinal primária (HELFAND et al., 1998). No entanto, outros autores argumentam que esses casos, distribuídos aleatoriamente na população, não sustentam a transmissão em uma população altamente vacinada (FRANK et al., 1985).

Com referência à falha vacinal secundária, também não existe consenso se a mesma pode constituir um resíduo de suscetíveis relevante, contribuindo para surtos de sarampo em populações altamente vacinadas (FRANK et al., 1985; MATHIAS et al., 1989; PANNUTI et al., 2004).

Ainda com referência à possibilidade de ocorrência de surtos entre população altamente vacinada, vale assinalar que em grandes centros urbanos a cobertura vacinal média do município pode não refletir a heterogeneidade de coberturas em diferentes seguimentos populacionais (MORAES et al., 2000; DELAMONICA et al., 2005), pois a mesma é calculada a partir do número de doses aplicadas de vacina e a população 
estimada dos menores de um ano de idade residentes no município, o que possibilita imprecisões nesse cálculo (MORAES et al., 2000).

Entretanto, existem evidências que em populações com alta cobertura vacinal, mas heterogênea, a transmissão do sarampo pode ser interrompida sem o estabelecimento de uma sólida imunidade de grupo, sugerindo a existência de um limiar na fração mínima de suscetíveis para desencadear um surto (WALLINGA et al., 2005).

Se os dados relativos à distribuição dos casos possíveis de sarampo no tempo (Figuras 5 e 7) permitem várias hipóteses, por outro lado, fortalecem uma avaliação positiva da vigilância quanto à oportunidade na identificação dos casos e na realização de medidas imediatas e efetivas de controle. A consistência dessa avaliação fica evidente, com a elevação do número de casos, expressa em picos, que não se sustenta em semanas epidemiológicas sucessivas (Figura 6).

A análise da distribuição dos casos no tempo aponta uma clara distribuição sazonal, com maior proporção dos casos $(35,2 \%)$ entre os meses de setembro e novembro, semelhante à sazonalidade do sarampo na era pré-vacinal, que apresentava maior incidência entre o final do inverno e durante a primavera (ARANDA, 2006; MOSS e OTA, 2007).

A rubéola e o eritema infeccioso também apresentam sazonalidade semelhantes a do sarampo (YOUNG e BROWN, 2004; SATO, 2006; TEDESCO E AMATO NETO, 2006; CDC, 2007b). Portanto, essa característica não constitui aspecto que distingue o sarampo das demais doenças febris exantemáticas, dificultando a formulação de hipóteses relativas ao tipo de infecção associada aos casos possíveis de sarampo.

A distribuição espacial dos casos apresenta maior concentração, em todo o período de interesse, na área metropolitana da capital. Entretanto, as maiores taxas de incidência foram apresentadas pelos municípios do interior do estado com pequenas populações. Como a transmissão do sarampo e de outros vírus associados às doenças febris exantemáticas é mais intensa em áreas urbanas de elevada densidade populacional, em virtude da maior probabilidade de contato entre indivíduos suscetíveis e infectados (CUTTS e 
MARKOWITZ, 1994; SES, 1998), é possível que o maior risco observado em populações menores deva-se ao acaso, em virtude do pequeno denominador.

Analisando-se a distribuição no tempo e no espaço (Figuras 9 e 10) não é possível identificar um padrão de comportamento que possa sugerir a existência de uma cadeia de transmissão para o sarampo ou mesmo de outra doença febril exantemática. Portanto, a análise dos dados sob esse aspecto não contribui para a elaboração de hipóteses consistentes.

\section{Manifestações clínicas}

A baixa proporção de casos que cumpre o critério de clínica específica de sarampo (Tabela 3) merece algumas considerações.

A atenuação das manifestações clínicas do sarampo entre casos previamente vacinados contra essa doença (EDMONSON et al., 1990; HUISS et al., 1997; DAMIEN et al., 1998; HELFAND et al., 1998; VARDAS e KREIS, 1999) dificulta a identificação, investigação e confirmação do diagnóstico dos casos suspeitos. Esses casos geralmente apresentam pródromos mais curtos e febre baixa (ROTA et al., 1995; ISHIWADA et al., 2001).

Existem evidências que a ocorrência de infecção pelo vírus do sarampo seguida de sintomatologia clássica da doença em pessoas previamente vacinadas, pressupõe intensa exposição (AABY, 1986; HELFAND et al., 1998; VARDAS e KREIS, 1999). No entanto, existem relatos, durante epidemias, de infecções subclínicas identificadas, por técnicas sorológicas e pelo isolamento do vírus, em pessoas vacinadas e reexpostas ao vírus do sarampo, (REYES et al., 1987; VAN BINNENDIJK et al., 2003), fato que sugere a possibilidade de transmissão secundária.

Porém, ainda não foi comprovada a transmissão do sarampo a partir de casos sem a sintomatologia clássica da doença (EDMONSON et al., 1990; ROTA et al., 1995; HUISS et al., 1997; DAMIEN et al., 1998; HELFAND et al., 1998; VARDAS e KREIS, 1999; WHITTLE et al., 1999). Fato que sugere que casos assintomáticos ou modificados de sarampo em 
pessoas previamente vacinadas não tenham importância na cadeia de transmissão em populações imunes (EDMONSON et al., 1990; HELFAND et al., 1998; LIEVANO et al., 2004).

Se de um lado a proporção de casos com clínica específica de sarampo é baixa (Tabela 3), por outro, a sua distribuição com proporções decrescentes entre não vacinados, expostos à vacina no passado e recentemente é consistente.

Em estudo realizado em área de elevada incidência de sarampo (Zimbabwe), HELFAND et al. (2003) verificaram que $72 \%$ dos casos que apresentaram quadro clínico específico de sarampo foram confirmados pela presença de anticorpos específicos da classe IgM. Tal resultado sugere que mesmo em área de elevada incidência de sarampo, o critério clínico de confirmação de caso não apresenta um valor preditivo tão alto quanto poderia ser esperado. Por outro lado, OLIVEIRA et al. (2006) verificaram baixo valor preditivo positivo da definição de caso suspeito de sarampo no Brasil em períodos não epidêmicos, consistente com os $15,3 \%$ de casos com clínica específica de sarampo verificados nesta pesquisa.

Como uma das características da vigilância do sarampo voltada à eliminação da doença é ser suficientemente sensível para identificar rapidamente uma possível fonte de infecção e efetivar as medidas imediatas de controle, pode ser aceitável uma definição de caso suspeito pouco específica e de baixo valor preditivo positivo, ainda que como resultado seja a elevação do custo do programa.

As manifestações clínicas do sarampo (exantema, febre, tosse, conjuntivite, coriza e Koplik) (Tabela 4) foram mais freqüentes, entre os não vacinados, seguidos pelos expostos recentemente à vacina $\mathrm{e}$, por fim, pelos vacinados no passado.

As proporções tanto das manifestações clínicas mais relevantes como das complicações conferem plausibilidade à hipótese de que, possivelmente, uma pequena parcela dos casos esteja associada à infecção pelo vírus do sarampo. 
Verifica-se que as freqüências de complicações (Tabela 5) seguem uma gradação coerente com a condição do caso, similar as proporções dos casos com clínica específica, pois foram mais freqüentes entre os não vacinados, seguidos pelos vacinados no passado e por fim pelos casos expostos recentemente à vacina.

A gravidade do sarampo no Brasil, fundamentada em dados de letalidade verificada na epidemia de 1997 (DOMINGUES et al., 1997), é semelhante àquela encontrada nos EUA no início da década de 1990, aproximadamente 0,1\% (GINDLER et al., 1992).

As complicações encontradas por GINDLER et al. (1992) de 8,2\% diarréia, $5,8 \%$ de pneumonia e $6,4 \%$ de otite média aguda são muito semelhantes às proporções encontradas no presente estudo, com exceção da frequêencia de pneumonia que foi menor neste estudo (0,9\%). Por sua vez, os resultados encontrados nesta pesquisa, com exceção das diarréias, pouco diferem das complicações referidas por ATTI et al. (2006), 3,9\% de otites, $2,1 \%$ de pneumonias e $0,6 \%$ de diarréias, em estudo recente de um surto na Itália.

Vários estudos têm sido realizados em diversos países para identificar a etiologia das doenças febris exantemáticas, todos eles registram que doenças com quadro clínico semelhante ao sarampo e a rubéola, em crianças vacinadas contra o sarampo, são freqüentemente causadas por outros vírus (DAVIDKIN et al., 1998; OLIVEIRA et al., 2001; OLIVEIRA et al., 2002; RAMSAY et al., 2002; ALONSO et al., 2003). A grande semelhança de sinais e sintomas é responsável pela dificuldade do diagnóstico e permite que o quadro clínico do sarampo seja confundido com o de outras doenças febris exantemáticas (DAVIDKIN et al., 1998; OLIVEIRA et al., 2001; OLIVEIRA et al., 2002; RAMSAY et al., 2002; ALONSO et al., 2003). 


\section{Considerações Finais}

Este estudo constituiu uma análise a posteriori de dados secundários do sistema passivo de vigilância da síndrome febril exantemática, distinguindo-se daquela realizada na rotina da vigilância, não só por ser retrospectiva, mas por ter sido elaborada, não a partir da exaustiva investigação individual dos casos, mas da análise do conjunto das informações disponíveis.

Pelas limitações assinaladas no início da Discussão, o estudo não permite avaliação conclusiva a respeito da circulação do vírus do sarampo no estado de São Paulo, no período de estudo, mas aponta para a necessidade da investigação exaustiva de possíveis resíduos de fontes de infecção entre: menores de nove meses, primo vacinados contra o sarampo em idade inferior a 10 meses, mulheres em idade fértil e casos não expostos à vacina contra o sarampo. A utilização do teste de avidez e a inclusão da tentativa de isolamento do vírus e de sua caracterização molecular seriam de grande utilidade na investigação dos casos possíveis não expostos à vacina.

A vigilância por síndrome é uma estratégia que passou a ser utilizada no Brasil, nos últimos anos, com várias experiências bem sucedidas (MOREIRA, 2001; MS, 2007). A experiência do estado de São Paulo com a vigilância da síndrome febril exantemática mostrou alta sensibilidade, elevado grau de oportunidade na investigação propiciando ações de controle muito efetivas. 


\section{CONCLUSÃO}

- A investigação dos casos foi realizada em até oito dias após o início do exantema em $90,1 \%$ dos casos. O tempo médio para a investigação foi de três dias e a mediana de dois dias.

- A investigação etiológica foi efetuada em 97\% dos casos, em até 28 dias após o início do exantema, em período adequado, abaixo dos 30 dias preconizados pela OPAS.

- Entre os casos estudados houve predomínio do sexo feminino $(56,6 \%)$ e os grupos etários mais representados foram de nove a 11 meses (36,5\%), um ano $(32,8 \%)$ e cinco anos ou mais $(19,6 \%)$.

- Do grupo estudado, 25/463 (5,4\%) casos referiram contato com pessoas apresentando quadro clínico semelhante a sarampo e/ou rubéola.

- A distribuição no tempo e no espaço não sugere a ocorrência de casos relacionados entre si. A distribuição no tempo mostrou variação sazonal.

- A definição de caso suspeito e de clínica específica para sarampo representaram 58,7\% e $15,3 \%$ dos casos, respectivamente. As manifestações clínicas mais freqüentes foram: exantema $(97,0 \%)$, febre $(85,3 \%)$, coriza $(48,4 \%)$ e tosse $(45,6 \%)$.

- A maioria dos pacientes não apresentou complicações. A diarréia foi a única complicação que apresentou diferença entre casos expostos e não expostos à vacina $(p<0,05)$. A hospitalização foi necessária em quatro $(0,9 \%)$ casos. 
- A maioria dos casos $(84,4 \%)$ apresentou vacinação documentada para o sarampo.

- Dos 463 casos possíveis de sarampo, 64,1\% foram classificados como casos expostos à vacina e $29,8 \%$ como casos não expostos à vacina.

- Dos casos expostos à vacina do sarampo, $(N=297), 97,3 \%$ concentraramse nas faixas etárias preconizadas para a vacinação contra o sarampo. Nesse grupo a clínica específica foi apresentada por $12,8 \%$ dos casos.

- Dos casos não expostos e vacinados, $(N=94), 55,7 \%$ concentraram-se na faixa etária de um ano a nove anos de idade e 18,1\% apresentaram clínica específica de sarampo. Nesse grupo, $41 / 94$ (43,6\%) receberam a primeira dose de vacina contra o sarampo com menos de dez meses de idade.

- Dos casos não expostos e não vacinados, $(N=44)$, as faixas etárias mais atingidas foram os menores de nove meses (52,3\%) e os maiores de 14 anos (34,1\%). A clínica específica foi apresentada por $27,3 \%$ dos casos.

- O estudo aponta para a necessidade da investigação exaustiva de possíveis resíduos de fontes de infecção entre: menores de nove meses, primo vacinados contra o sarampo em idade inferior a 10 meses, mulheres em idade fértil e casos não expostos à vacina contra o sarampo. 


\section{REFERÊNCIAS}

Aaby P, Bukh J, Leerhoy J, Lisse IM, Mordhorst CH, Pedersen IR.

Vaccinated children get milder measles infection: a community study from Guinea-Bissau. J Infect Dis. 1986;154(5):858-63.

Academia americana de pediatria. Comitê de doenças infecciosas. Sarampo. In: Pickering LK, editor. Red book: relato do comitê de doenças infecciosas. 26. ed. Elk Grove Village (IL); 2003. p. 555-66.

Alonso TV, Costa MG, Recio MJR, Higuera OS; Red de médicos centinelas de Castila y Leon. Incidencia y características clínicas de los exantemas maculopapulares de etiologia viral. Aten Primaria. 2003;32:517-23.

Aranda, CMSS. Sarampo. In: Lopes AC, editor, Amato Neto V, co-editor. Tratado de clínica médica. São Paulo: Roca; 2006. v. 3. p. 3823-34.

Arita I, Wickett J, Nakane M. Eradication of infeccious diseases: its concept, then and now. Jpn J Infect Dis. 2004;57(1):1-6.

Atti MLC, Filia A, Massari M, Pizzuti R, Nicoletti L, D’Argenzio A et al. Assessment of measles incidence, measles-related complications and hospitalizations during an outbreak in a southern Italian region. Vaccine. 2006;24(9):1332-8.

Barros ENC, Silva MS. Vigilância epidemiológica do sarampo e da rubéola no município de Campinas (SP), Brasil: confiabilidade dos dados. Rev Panam Salud Publica. 2006;19(3):172-8.

Bellini WJ, Helfand RF. The challenges and strategies for laboratory diagnosis of measles in an international setting. J Infect Dis. 2003;187(Suppl 1):S283-90.

Bloom ME, Young NS. Parvoviruses. In: Knipe DM, Howley PM, editors. Fields virology. 4. ed. Philadelphia: Lippincott Williams \& Wilkins; 2001. p. 2361-79. 
Brown KE. Parvovirus B19. In: Mandell GL, Douglas RG, Bennett JE, Dolin $\mathrm{R}$, editors. Mandell, Douglas, and Bennett's Principles and practice of infectious diseases. 6. ed. New York: Elsevier/Churchill Livingstone; 2005. v. 2, p. 1891-8.

Camargo MCC, Moraes JC, Souza VAUF, Matos MR, Pannuti CS. Predictors related to the occurrence of a measles epidemic in the city of São Paulo in 1997. Pan Am Public Health. 2000;7(6):359-64.

CDC - Centers for Diseases Control and Prevention. Advances in Global Measles Control and Elimination: Summary of the 1997 International Meeting. MMWR Morb Mortal Wkly Rep. 1998;47(RR11):1-23.

CDC - Centers for Diseases Control and Prevention. Progress toward interrupting indigenous measles transmission - Region of the Americas, January - November 2001. MMWR Morb Mortal Wkly Rep. 2001;50 (50):1133-7.

CDC - Centers for Diseases Control and Prevention. Public health dispatch: absence of transmission of the $d 9$ measles virus - region of the Americas, november 2002 - march 2003. MMWR Morb Mortal Wkly Rep. 2003; 52(11):228-9.

CDC - Centers for Diseases Control and Prevention. Epidemiology and prevention of vaccine - preventable diseases: the pink book. Measles [monografia na internet]. Atlanta (GA); 2007a. [acesso em 18 maio 2007]. Disponível em: http:/ / www.cdc.gov/nip/publications/pink/meas.pdf CDC - Centers for Diseases Control and Prevention. Epidemiology and prevention of vaccine - preventable diseases: the pink book. Rubella [monografia na internet]. Atlanta (GA); 2007b. [acesso em 18 maio 2007]. Disponível em: http:/ / www.cdc.gov/nip/publications/pink/rube.pdf 
Chantler J, Wolinsky JS, Tingle A. Rubella virus. In: Knipe DM, Howley PM, editors. Fields virology. 4. ed. Philadelphia: Lippincott Williams \& Wilkins; 2001. p. 963-90.

Cutts FT, Markowitz LE. Successes and failures in measles control. J Infect Dis. 1994;170(Suppl 1):S32-41.

Damien B, Huiss S, Schneider F, Muller CP. Estimated susceptibility to asymptomatic secondary immune response against measles in late convalescent and vaccinated persons. J Med Virol. 1998;56:85-90.

Davidkin I, Valle M, Peltola H, Hovi T, Paunio M, Roivainen M, et al. Etiology of measles- and rubella-like illnesses in measles, mumps, and rubellavaccinated children. J Infect Dis. 1998;178(6):1567-70.

Delamonica E, Minujin A, Gulaid J. Monitoring equity in immunization coverage. Bull World Health Organ. 2005;83(5):384-91.

Dietz V, Rota J, Izurieta H, Carrasco P, Bellini W. The laboratory confirmation of suspected measles cases in settings of low measles transmission: conclusions from the experience in the Americas. Bull World Health Organ. 2004;82(11):852-7.

Domingues CMAS, Pereira MCCQ, Santos ED, Siqueira MM, Ganter B. A evolução do sarampo no Brasil e a situação atual. IESUS. 1997;1:7-19.

Donovan SM. False-positive results of an enzyme immunoassay for rubella IgM in a case of measles. Clin Infect Dis. 1997;24:271-2.

Edmonson MB, Addiss DG, McPherson JT, Berg JL, Circo SR, Davis JP. Mild measles and secondary vaccine failure during a sustained outbreak in a highly vaccinated population. JAMA. 1990;263:2467-71.

Erdman DD, Anderson LJ, Adams DR, Stewart JA, Markowitz LE, Bellini WJ. Evaluation of monoclonal antibody-based capture enzyme immunoassays for 
detection of specific antibodies to measles virus. J Clin Microbiol. 1991;29:1466-71.

Evans AS. The eradication of communicable diseases: myth or reality? Am J Epidemiol. 1985;122:199-207.

Foster SO, Macfarland DA, Jhon AM. Measles. In: Jamison DT, Mosley WH, Measham AR, Bobadilla JL, editors. Disease control priorities in developing countries. Washington (DC): Oxford University Press; 1993. p. 161-87.

Frank JA, Orenstein WA, Bart KJ, Bart SW, El-Tantawy N, Davis RM et al. Major impediments to measles elimination. AJDC. 1985;139:881-8.

Gershon AA. Measles virus (rubeola). In: Mandell GL, Douglas RG, Bennett JE, Dolin R, editors. Mandell, Douglas, and Bennett's Principles and practice of infectious diseases. 6. ed. New York: Elsevier/Churchill Livingstone; 2005a. v. 2, p. 2031-8.

Gershon AA. Rubella virus (German measles). In: Mandell GL, Douglas RG, Bennett JE, Dolin R, editors. Mandell, Douglas, and Bennett's Principles and practice of infectious diseases. 6. ed. New York: Elsevier/Churchill Livingstone; 2005b. v. 2, p. 1921-6.

Gindler JS, Atkinson WL, Markowitz LE. Update - the Unites States measles epidemic, 1989-1990. Epidemiol Rev 1992;14:270-6.

Griffin DE. Measles Virus. In: Knipe DM, Howley PM, editors. Fields virology. 4. ed. Philadelphia: Lippincott Williams \& Wilkins; 2001. p. 1401-41.

Hall CB, Long CE, Schnabel KC, Caserta MT, Mclntyre KM, Constanzo MA, et al. Human herpesvirus- 6 infection in children - a prospective study of complications and reactivation. N Engl J Med. 1994;331(7):432-8.

Hamkar R, Mahmoodi M, Nategh R, Jelyani KN, Estami MB, Mohktari-Azad. Distinguishing between primary measles infection and vaccine failure reinfection by IgG avidity assay. East Mediterr Health J. 2006;12(6):775-82. 
Harpaz R, Papania MJ. Can a minimum rate of investigation of measeslike illnesses serve as a standard for evaluating measles surveillance? J Infect Dis. 2004;189(Suppl 1):S204-9.

Helfand RF, Heath JL, Anderson LJ, Maes EF, Guris D, Bellini WJ. Diagnosis of measles with an IgM capture EIA: the optimal timing of specimen collection after rash onset. J Infect Dis. 1997;175:195-9.

Helfand RF, Kim DK, Gary Jr HE, Edwards GL, Bisson GP, Papania MJ, et al. Nonclassic measles infections in an immune population exposed to measles during a college bus trip. J Med Virol. 1998;56:337-41.

Helfand RF, Kebede S, Gary HE Jr, Beyene H, Bellini WJ. Timing of development of measles - specific immunoglobulin $M$ and $G$ after primary measles vaccination. Clin Diagn Lab Immunol. 1999;6:178-80.

Helfand RF, Chibi T, Biellik R, Shearley A, Bellini WJ. Negative impact of clinical misdiagnosis of measles on health workers' confidence in measles vaccine. Epidemiol Infect. 2003;132:7-10.

Henao-Restrepo AM, Strebel P, Hoekstra EJ, Birmingham M, Bilous J. Experience in global measles control, 1990-2001. J Infect Dis. 2003;187(Suppl 1):S15-21.

Huiss S, Damien B, Schneider F, Muller CP. Characteristics of asymptomatic secondary immune responses to measles virus in late convalescent donors. Clin Exp Immunol. 1997;109:416-20.

Hummel KB, Erdman DD, Health J, Bellini WJ. Baculovirus expression of the nucleoprotein gene of measles virus and utility of the recombinant protein in diagnostic enzyme immunoassays. J Clin Microbiol. 1992;30:2874-80.

Ishiwada N, Addae MM, Tetteh JKA, Yempewu SM, Ofori-Adjei D, Kamiya H, et al.. Vaccine-modified measles in previously immunized children in Accra, 
Ghana: clinical, virological and serological parameters. Trop Med Intern Health. 2001;6(9):694-8.

Kacica MA, Venezia RA, Miller J, Hughes PA, Lepow ML . Measles antibodies in women and infants in the vaccine era. J Med Virol. 1995;45:227-9.

Kuschnaroff TM. Sarampo. In: Focaccia R, editor. Veronesi. Tratado de Infectologia. São Paulo: Atheneu; 2005. p. 667-73.

Lievano FA, Papania MJ, Helfand RF, Harpaz R, Walls L, Katz RS, et al. Lack of evidence of measles virus shedding in people with inapparent measles virus infections. J Infect Dis. 2004;189(Suppl 1):S165-70.

Linnemann CC, Dine MS, Roselle GA. Askey A. Measles immunity after revaccination: results in children vaccinated before 10 months of age. Pediatrics. 1982; 69(3):332-5.

Marques HHS, Sakane PT. Exantema súbito. In: Lopes AC, editor, Amato Neto V, co-editor. Tratado de clínica médica. São Paulo: Roca; 2006. v. 3. p. 3845-7.

Mathias RG, Meekison WG, Arcand TA, Schechter MT. The role of secondary vaccine failures in measles outbreaks. Am J Public Health. 1989;79(4):475-8.

Moraes JC, Barata RCB, Ribeiro MCSA, Castro PC. Cobertura vacinal no primeiro ano de vida em quatro cidades do estado de São Paulo, Brasil. Rev Panan Salud Publica. 2000;8(5):332-41.

Moreira, SD. Vigilância sindrômica das doenças íctero febris agudas no Paraná. Saúde Paraná. 2001;4(15). [acesso em 30 de mai 2007]. Disponível em: www.saude.pr.gov.br/vigiepi/boletim/primavera_2001/sindromica.htm 
Moss WJ, Ota MO. Measles. In: Nelson KE \& Williams CM, editors. Infectious Disease Epidemiology. Theory and Practice. 2. ed. Boston: Jones and Bartlett Publishers; 2007. p. 601-36.

MS - Ministério da Saúde. Secretaria de Vigilância em Saúde. Manual de vigilância para a erradicação do sarampo, controle da rubéola e eliminação da síndrome da rubéola congênita (SRC). 3. ed. Brasília, DF; 2003.

MS - Ministério da Saúde. Secretaria de Vigilância em Saúde. Guia de vigilância epidemiológica. 6. ed. Brasília, DF: Ministério da Saúde; 2005. Sarampo; p.652-672 (Série A. Normas e materiais técnicos).

MS - Ministério da Saúde. Secretaria de Vigilância em Saúde. Coordenação de Vigilância das Doenças de Transmissão Respiratórias e Imunopreveníveis. Surto do sarampo no município de João Dourado/Bahia: todas as medidas de controle já foram realizadas [nota técnica n¹6/2006/COVER/CGDT/DEVEP/SVS/MS]. Brasília; 2006. [acesso em 16 jun 2007]. Disponível em http:/ / portal.saude.gov.br/portal/arquivos/pdf/nota_sarampo_0412.pdf MS - Ministério da Saúde. Doenças emergentes e reemergentes. Vigilância das síndromes febris ictéricas e/ou hemorrágicas agudas - a experiência brasileira. [documento na internet]. Brasília. [acesso em 30 maio 2007]. Disponível em: http:/ / portal.saude.gov.br/ portal/saude/visulisar_textocfm? Idtxt=22109.

Navalpotro D, Gimeno C, Navarro D. Concurrent detection of human herpesvirus type 6 and measles-specific IgMs during acute exanthematic human parvovirus B19 infection. J Med Virol. 2006;78:1449-51.

Oliveira MI, Curti SP, Figueiredo CA, Afonso AMS, Theobaldo M, Azevedo RS et al.. Rash after measles vaccination: laboratory analysis of cases reported in São Paulo, Brazil. Rev Saúde Pública. 2002;36(2):155-9. 
Oliveira SA, Siqueira MM, Camacho LAB, Nogueira RM, Spinetti CCJ, Garcia RCNC, et al. The aetiology of maculopapular rash diseases in Niterói, state of Rio de Janeiro, Brazil: implications for measles surveillance. Epidemiol Infect. 2001;127:509-16.

Oliveira SA, Camacho LAB, Pereira ACM, Setúbal S, Nogueira RMRN, Siqueira MM. Assessment of the performance of a definition of a suspected measles case: implications for measles surveillance. Pan Am Public Health. 2006;19(4):229-35.

Oshitani H, Suzuki H, Mpabalwani M, Mizuta K, Kasolo FC, Luo NP et al.. Laboratory diagnosis of acute measles infections in hospitalized children in Zambia. Trop Med Int Health. 1997;2(7):612-6.

Otten Jr MW, Okwo-Bele JM, Kezaala R, Biellik R, Eggers R, Nshimirimana D. Impact of alternative approaches to accelerated measles control: experience in the African Region, 1996-2002. J Infect Dis. 2003;187(Suppl 1):S36-43.

Ozanne G, D'Halewyn M-A. Performance end reliability of the Enzygnost measles enzyme-linked immunosorbent assay for detection of measles virusspecific immunoglobulin $\mathrm{M}$ antibody during a large measles epidemic. J Clin Microb. 1992;30:564-9.

PAHO - Pan American Health Organization. Measles case classification: frequent dilemmas in the field. EPI Newsl. 2001a;23(5):4-5.

PAHO - Pan American Health Organization. Measles case classification II: frequent dilemmas in the field. EPI Newsl. 2001b;23(6):3-4.

Pannuti CS, Morello RJ, Moraes JC, Curti SP, Afonso AMS, Camargo MCC. Identification of primary and secondary measles vaccine failures by measurement of immunoglobulin $\mathrm{G}$ avidity in measles cases during the 1997 São Paulo epidemic. Clin Diagn Lab Immunol. 2004;11(1):119-22. 
Poland GA, Jacobson RM, Thampy AM, Colbourne AS, Wollan PC, Lipsky JJ, Jacobson SJ. Measles reimmunization in children seronegative after initial immunization. JAMA. 1997; 277(14):1156-8.

Prevots DR, Parise MS, Segatto TCV, Siqueira MM, Santos ED, Ganter B, et al. Interruption of measles transmission in Brasil, 2000-2001. J Infect Dis. 2003;187(Suppl 1):S111-20.

Quadros CA, Olive JM, Hersh BS, Strassburg MA, Henderson DA, Bennett $\mathrm{DB}$, et al. Measles elimination in the Américas: envolving estrategies. JAMA. 1996;275 (3):224-9.

Quadros CA. History and prospects for viral disease eradication. Med Microbiol Immunol. 2002;191:75-81.

Quadros CA, Izurieta H, Carrasco P, Brana M, Tambini G. Progress toward measles eradication in the region of the Americas. J Infect Dis. 2003;187(Suppl 1):S102-10.

Quadros CA. Can measles be eradicated globally? Bull World Health Organ. 2004;82:134-8.

Ramsay M, Reacher M, O'Flynn C, Buttery R, Hadden F, Cohen B, et al. Causes of morbiliform rash in a highly immunized English population. Arch Dis Child. 2002;87:202-6.

Ratnam S, Tipples G, Head C, Fauvel M, Fearon M, Ward BJ. Performance of indirect immunoglobulin M (IgM) serology tests and IgM capture assays for laboratory diagnosis of measles. J Clin Microbiol. 2000;38(1):99-104.

Reyes MA, De Borrero MF, Roa J, Bergonzoli G, Saraiva NG. Measles vaccine failure after documented seroconversion. Pediatr Infect Dis J. 1987;6:848-51. 
Rota PA, Khan AS, Durigon E, Yuran T, Villamarzo YS, Bellini WJ. Detection of measles virus RNA in urine specimens from vaccine recipients. J Clin Microbiol. 1995;33(9):2485-8.

Sato, HK. Rubéola. In: Lopes AC, editor, Amato Neto V, co-editor. Tratado de clínica médica. São Paulo: Roca; 2006. v. 3. p. 3839-45.

SEADE - Fundação Sistema Estadual de Análise de Dados. Perfil municipal: São Paulo [dados estatísticos na internet]. São Paulo; 2006 [acesso em 19 jan 2006]. Disponível em: http://www.seade.gov.br/produtos/perfil/perfil.php

SES - Secretaria de Estado da Saúde de São Paulo. Centro de Vigilância Epidemiológica. Treinamento básico de vigilância epidemiológica. Módulo específico: sarampo e rubéola. São Paulo; 1998.

SES - Secretaria de Estado da Saúde de São Paulo. Centro de Vigilância Epidemiológica. Guia de vigilância para a erradicação do sarampo, controle da rubéola e da síndrome da rubéola congênita. São Paulo; 2002.

Souza VAUF, Pannuti CS, Sumita LM, Andrade Jr HF. Enzyme-linked immunosorbent assay - lgG antibody avidity test for single sample serologic evaluation of measles vaccines. J Med Virol. 1997;52:275-9.

Stewien KE, Lima LRAV, Botosso VF, Oliveira MI, Fagundes SN, Nogueira $\mathrm{MB}$, et al. Clinical and laboratory evaluation of measles like rash in children and young adults. Braz J Microbiol. 2000;31:281-5.

Straus SE. Human herpesvirus types 6 and 7. In: Mandell GL, Douglas RG, Bennett JE, Dolin R, editors. Mandell, Douglas, and Bennett's Principles and practice of infectious diseases. 6. ed. New York: Elsevier/Churchill Livingstone; 2005. v. 2, p.1821-5.

Szenborn L, Tischer A, Pejcz J, Rudkowski Z, Wójcik, M. Passive acquired immunity against measles in infants born to naturally infected and vaccinated mothers. Med Sci Monit. 2003;9(12):CR541-6. 
Tedesco J, Amato Neto V. Eritema infeccioso. In: Lopes AC, editor, Amato Neto V, co-editor Tratado de clínica médica. São Paulo: Roca; 2006. v. 3. p. 3847-50.

Thomas HI, Barrett E, Hesketh LM, Wynne A, Morgan-Capner P. Simultaneous IgM reactivity by EIA against more than one virus in cases of measles, parvovirus B19 and rubella infection. J Clin Virol. 1999;14(2):10718.

Tipples GA, Hamkar R, Mohktari-Azad T, Gray M, Parkyn G, Head C, et al.. Assessment of immunoglobulin $M$ enzyme immunoassays for diagnosis of measles. J Clin Microbiol. 2003; 41(10):4790-2.

Tuokko H. Comparison of nonspecific reactivity in indirect and reverse immunoassays for measles and mumps immunoglobulin $\mathrm{M}$ antibodies. J Clin Microbiol. 1984;20(5):972-6.

Van Binnendijk RS, Van den Hof S, Van den Kerkhof H, Kohl RHG, Woonink F, Berbers GAM, et al. Evaluation of serological and virological tests in the diagnosis of clinical and subclinical measles virus infections during an outbreak of measles in the Netherlands. J Infect Dis. 2003;188:898-903.

Vardas E, Kreis S. Isolation of measles virus from a naturally-immune, asymptomatically re-infected individual. J Clin Virol. 1999;13:173-9.

Venczel L, Rota J, Dietz V, Morris-Glasgow V, Siqueira M, Quirogz E, et al. The measles laboratory network in the region of the Américas. J Infect Dis. 2003;187(Suppl 1):S140-5.

Waldman EA. Vigilância como prática de saúde pública. In: Campos GWS, Minayo MCS, Akerman M, Drumond Jr M, Carvalho YM, organizadores. Tratado de Saúde Coletiva. 1 ed. São Paulo: Hucitec / Rio de Janeiro: Fiocruz, 2006. 
Wallinga J, Heijne JCM, Kretzschmar M. A measles epidemic threshold in a highly vaccinated population. PLoS Med. 2005;2(11):1152-7.

Whittle HC, Aaby P, Samb B, Jensen H, Bennett J, Simondon F. Effect of subclinical infection on maintaining immunity against measles in vaccinated children in West Africa. Lancet. 1999;353:98-102.

WHO - World Health Organization. WHO-UNICEF joint statement on strategies to reduce measles mortality worldwide. Wkly Epidemiol Rec. 2002;27:224-8.

WHO - World Health Organization. Update of the nomenclature for describing the genetic characteristics of wild-type measles viruses: new genotypes and reference strains. Wkly Epidemiol Rec. 2003;27:229-40.

WHO - World Health Organization. New genotype of measles virus and update on global distribution of measles genotypes. Wkly Epidemiol Rec. 2005;40:347-51.

Yamanishi K. Human Herpesvirus 6 and Human Herpesvirus 7. In: Knipe DM, Howley PM, editors. Fields virology. 4. ed. Philadelphia: Lippincott Williams \& Wilkins; 2001. p. 2785-2801.

Young NS, Brown KE. Mechanisms of disease Parvovirus B19. N Engl J Med 2004;350:586-97. 


\section{ANEXOS}

\section{ANEXO 1. Ficha de investigação de sarampo e rubéola (2000)}

Ficha Individual de Investigação específica de Doenças Exantemáticas Febris - Sarampo e Rubéola (modelo para o ano 2000)

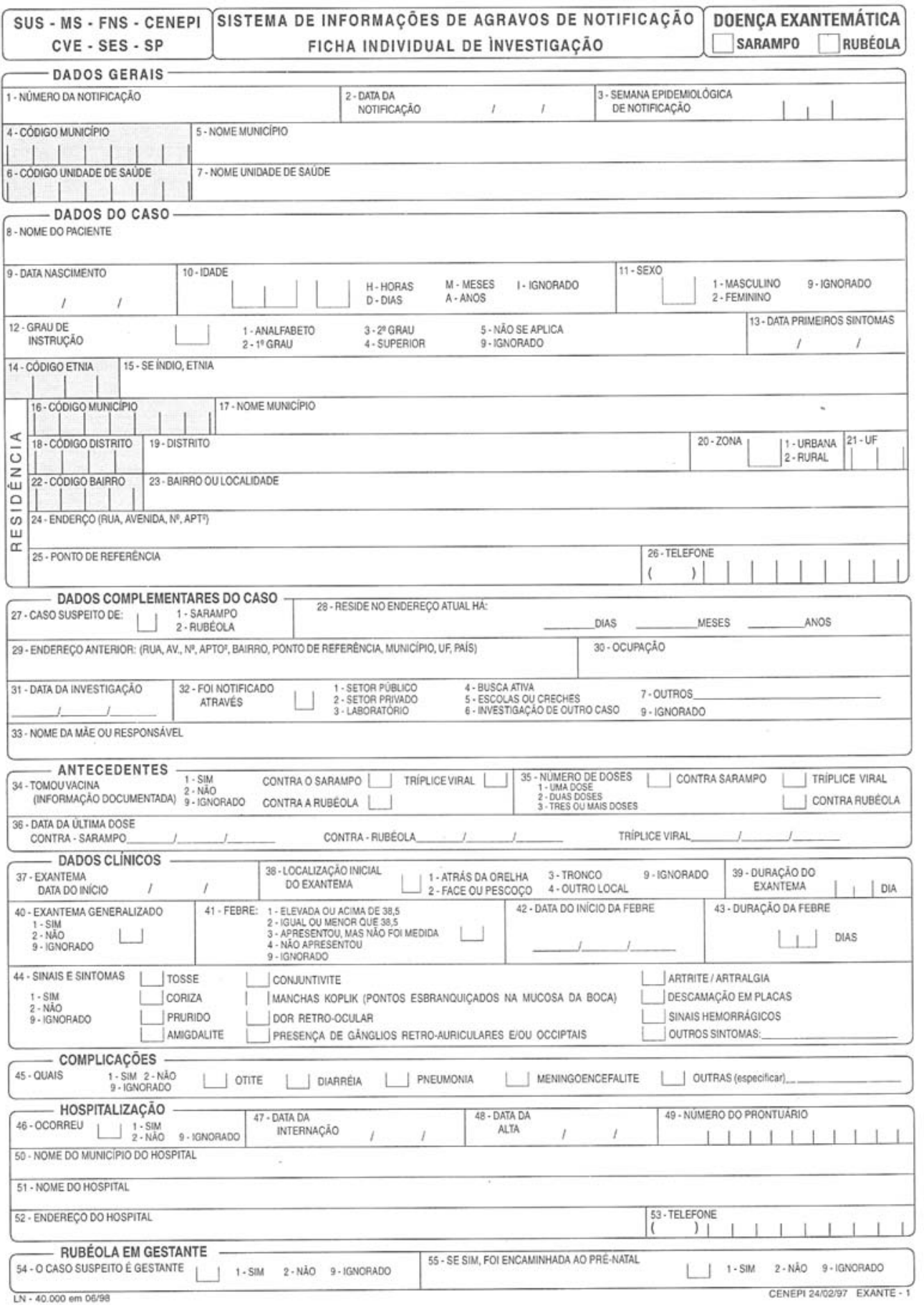




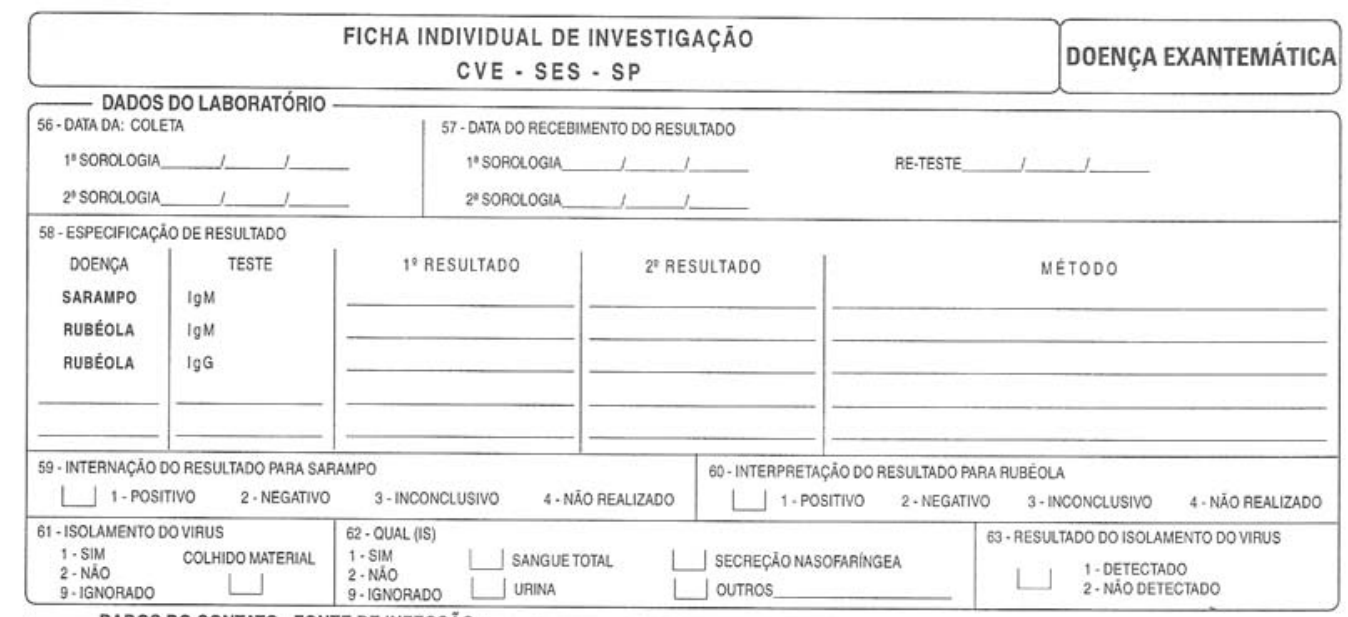

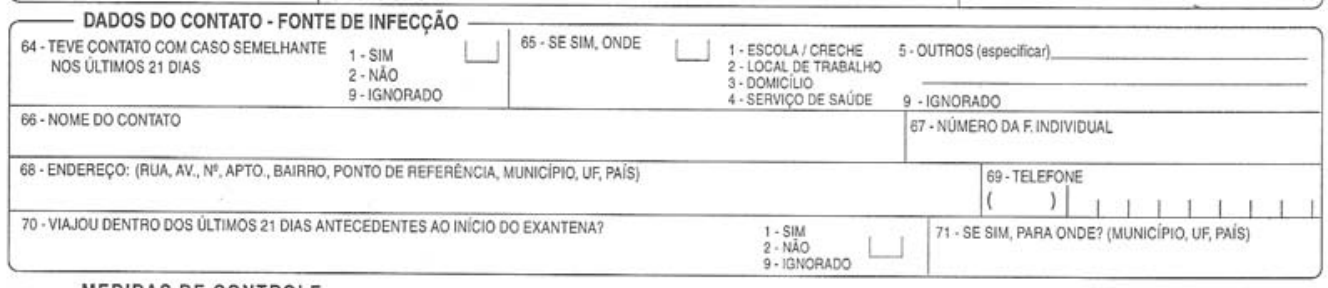

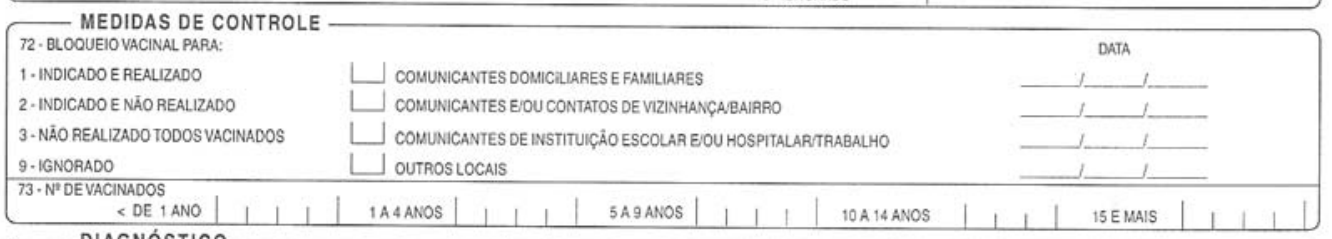

\begin{tabular}{|c|c|c|c|}
\hline 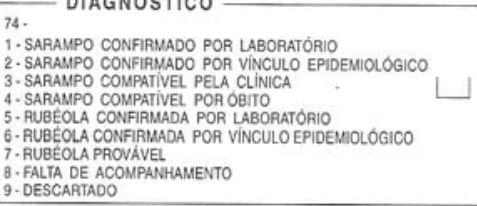 & $\begin{array}{l}\text { 75-CRITÉRIO DO DESCARTE } \\
\text { 1. LABORATÓRIO } \\
\text { 2. VINCULO-EPIDEMIOLOGICO } \\
\text { 3. CLINICO }\end{array}$ & $\begin{array}{l}\text { 76. DIAGNÓSTICO DO CASO DESCARTADO } \\
\text { 1. EVENTO ADVERSO A VACINA } \\
\text { 2. ESCARLATINA } \\
\text { 3. EXANTEMA SÜBITO } \\
\text { 4. DENGE } \\
\text { 5. OUTRAS EXANTEMÁTICAS: }\end{array}$ & $\begin{array}{l}77 \text { - CASO } \\
\text { 1-AUTOCTONE } \\
\text { 2- IMPORTADO }\end{array}$ \\
\hline \multirow{2}{*}{ 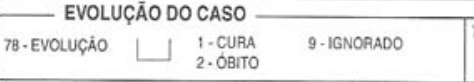 } & & & \\
\hline & 79- DATA DO ÓBITO & CAUSA: & \\
\hline
\end{tabular}

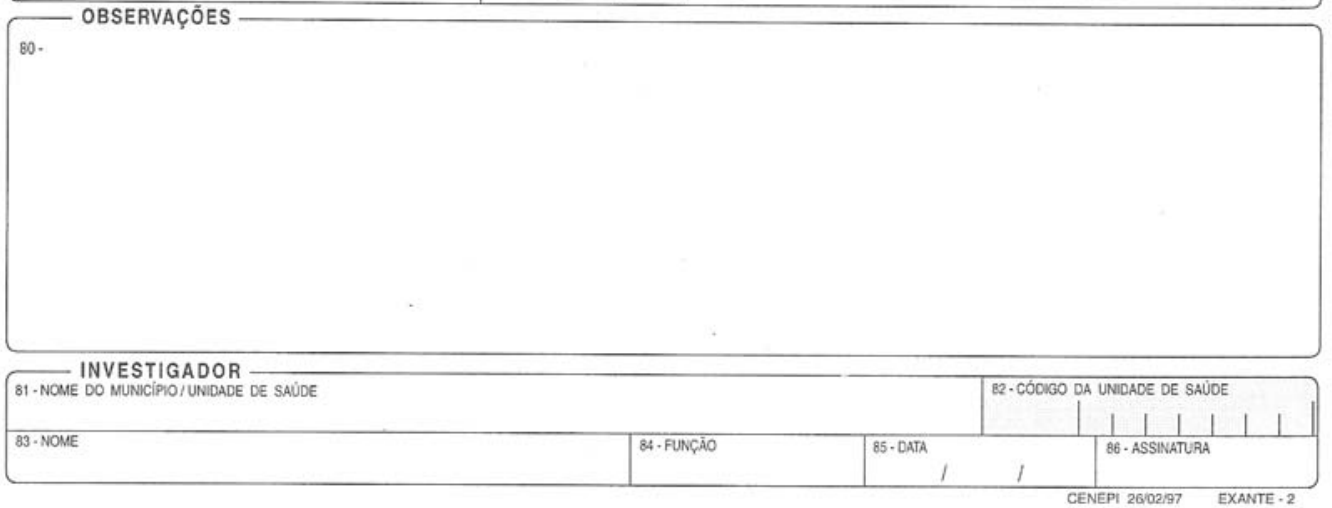




\section{ANEXO 2. Ficha de investigação sarampo e rubéola (2001 a 2004)}

Ficha Individual de Investigação específica de Doenças Exantemáticas Febris - Sarampo e Rubéola (modelo para os anos 2001 a 2004)

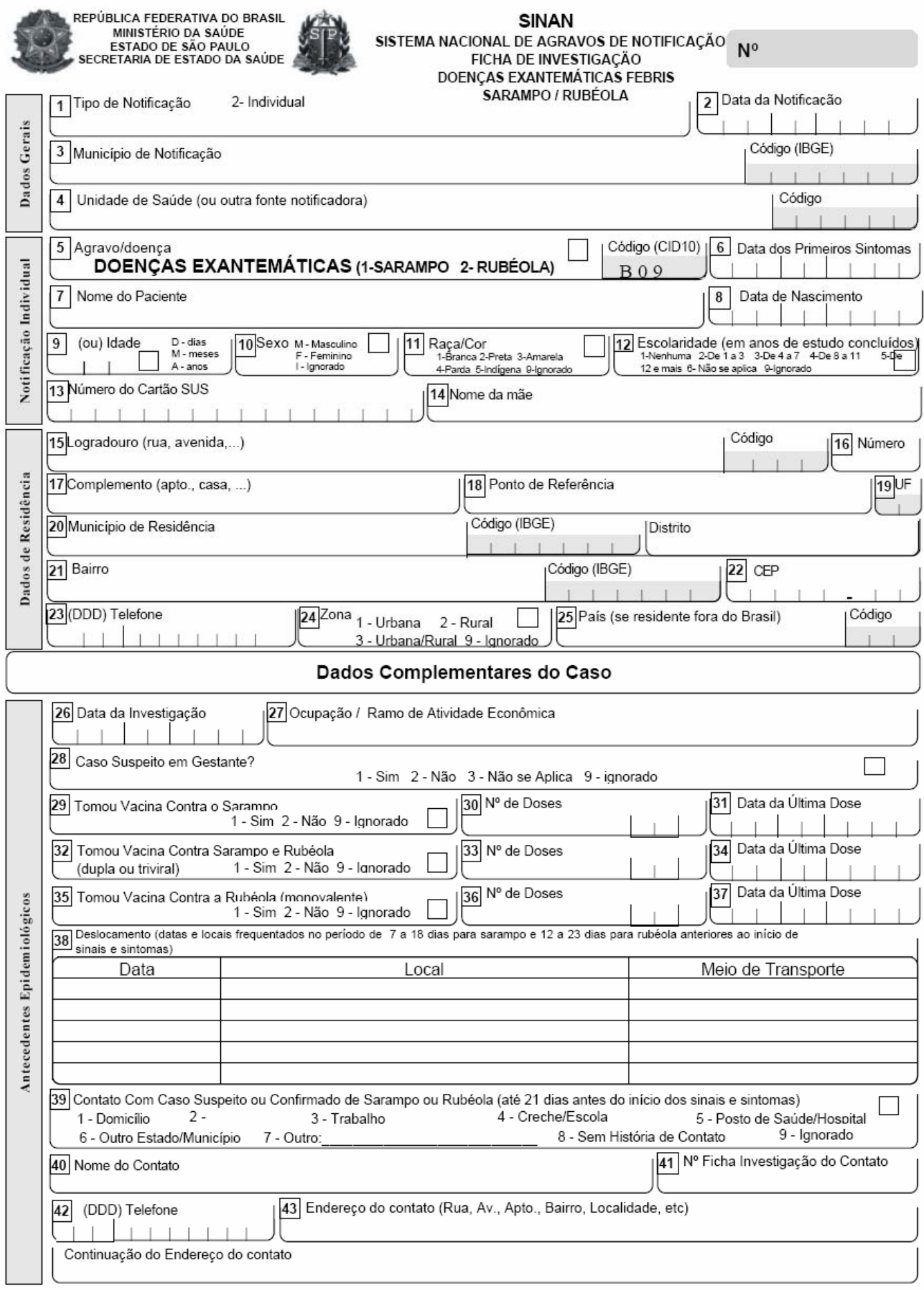




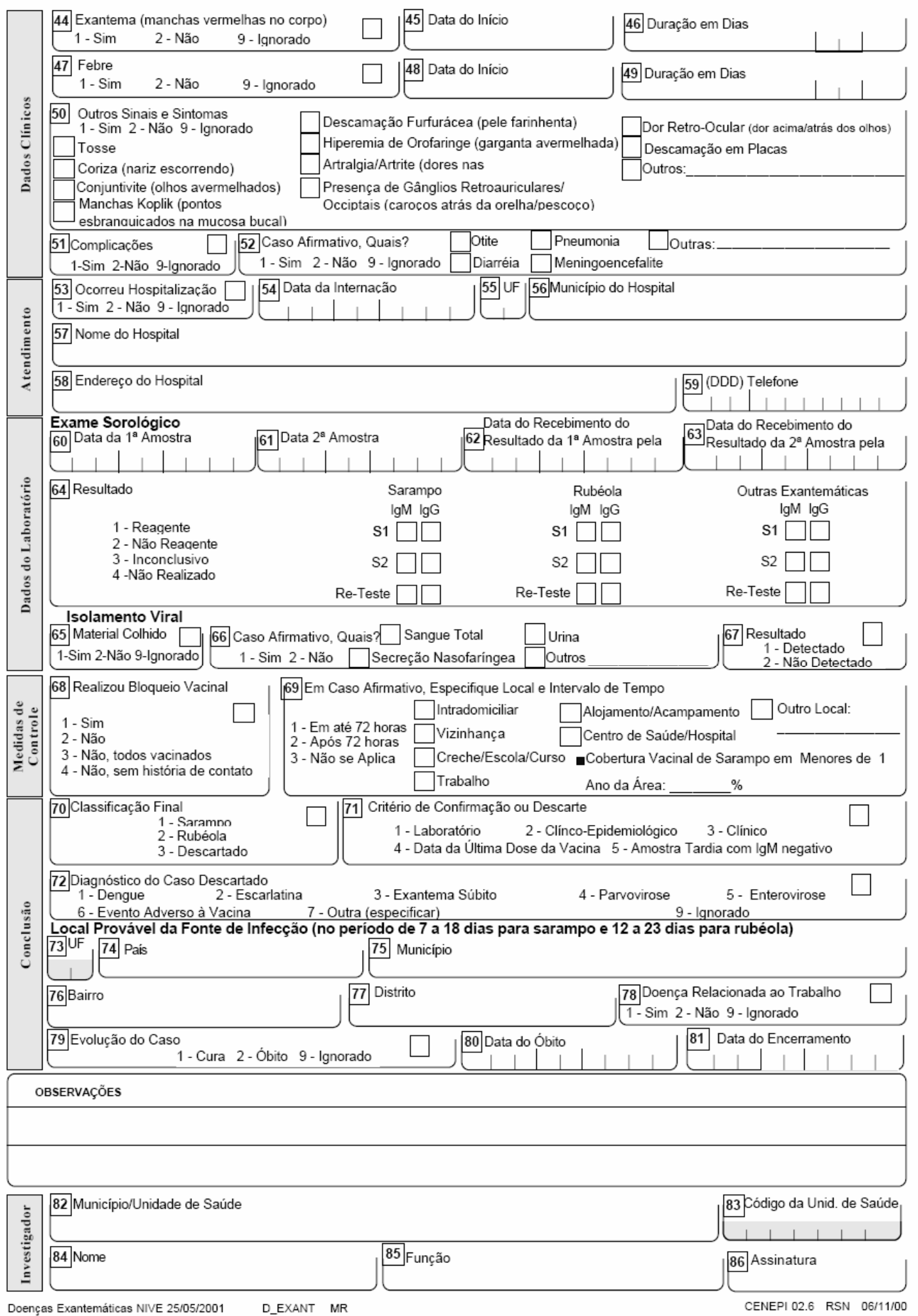




\title{
ANEXO 3. Termo de compromisso
}

\author{
TERMO DE COMPROMISSO
}

Nós abaixo assinados, investigadores responsáveis pelo projeto "Análise dos Casos com IgM Reagente contra Sarampo, Estado de São Paulo, 2000 a 2004", comprometemo-nos a preservar o anonimato dos sujeitos da pesquisa, bem como garantir o sigilo e a confidencialidade no manuseio das informaçōes relativas aos pacientes estudados.

Garantimos, por outro lado, que os dados coletados serão utilizados exclusivamente com os propósitos estabelecidos nos objetivos dessa pesquisa.

São Paulo, 18 de fevereiro de 2006

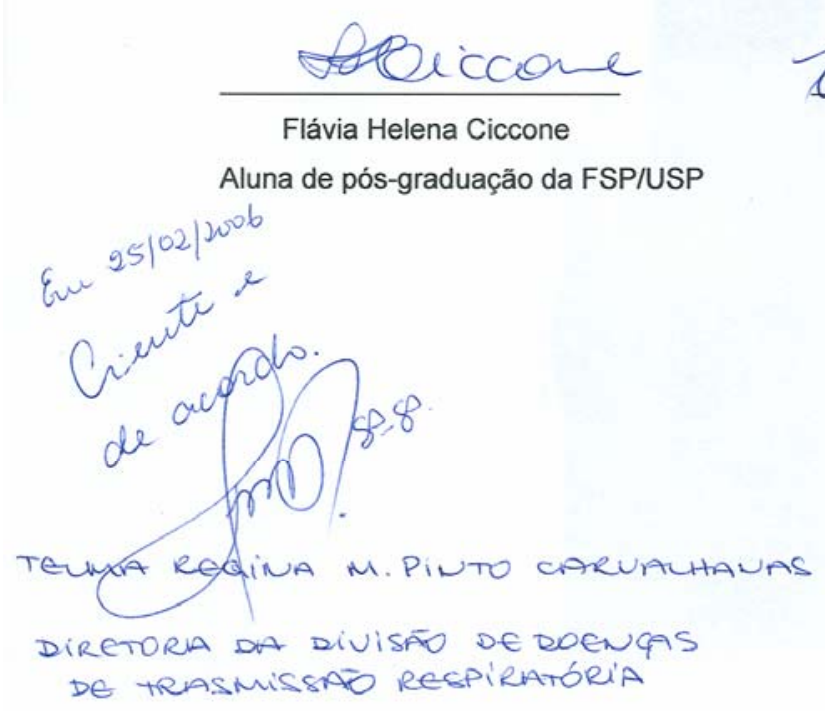

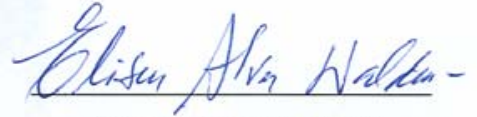

Eliseu Alves Waldman

Orientador 


\title{
ANEXO 4. Aprovação do comitê de ética
}

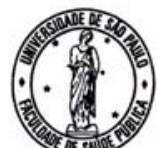 \\ UNIVERSIDADE DE SÃO PAULO \\ FACULDADE DE SAÚDE PÚBLICA \\ COMITÊ DE ÉTICA - COEP
}

Av. Dr. Arnaldo, 715 - Assessoria Acadêmica - CEP 01246-904 - São Paulo - Brasil Of.COEP/117/2006

05 de abril de 2006

Pelo presente, informo que o Comitê de Ética em Pesquisa da Faculdade de Saúde Pública da Universidade de São Paulo - COEP, analisou em sua 5. a/06 Sessão Extraordinária, realizada nesta data, de acordo com os requisitos da Resolução CNS/196/96 e suas complementares, o Protocolo de Pesquisa n. ${ }^{\circ}$ 1521, intitulado: "ANÁLISE DOS CASOS COM IGM REAGENTE CONTRA SARAMPO, ESTADO DE SÃO PAULO, 2000 A 2004", apresentado pela pesquisadora FLÁVIA HELENA CICCONE, e o considerou aprovado.

Atenciosamente,

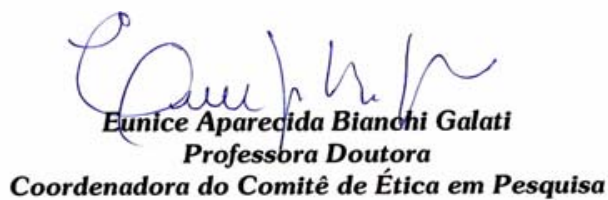

Ilm.. ${ }^{\circ} \mathrm{Sr}$

Prof. Dr. Eliseu Alves Waldman

Departamento de Epidemiologia 